\title{
TTP SR1-6-WT-31, Milestone C.3-2 Annual Report on Clemson/INEEL Melter Work
}

by

D. F. Bickford

Westinghouse Savannah River Company

Savannah River Site

Aiken, South Carolina 29808

D. C. Iverson

R. P. Singer

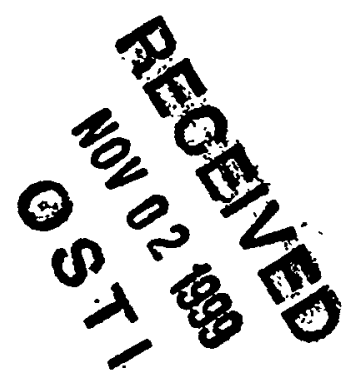

H. N. Guerrero

M. E. Smith

E. K. Hansen

J. C. George

This paper was prepared in connection with work done under the above contract number with the U.S. Department of Energy. By acceptance of this paper, the publisher and/or recipient acknowledges the U.S. Government's right to retain a nonexclusive, royalty-free license in and to any copyright covering this paper, along with the right to reproduce and to authorize others to reproduce all or part of the copyrighted paper. 
TTP SR1-6-WT-31

Milestone C.3-2

Milestone C.1-3
Annual Report on Clemson/INEEL Melter Work

Status of Replacement Heater Modules for Pour Spout Heater

D. R. Bickford, D. C. Iverson, H. N. Guerrero, M. E. Smith, E. K. Hansen, J. C. George, R. P. Singer

Approved by

E. W. Holtzscheiter, Research Manager

Defense Waste Processing Technology

Issue Date: August 30, 1999

Westinghouse Savannah River Co.

Savannah River Site

Aiken, SC 29808 


\section{DISCLAIMER}

This report was prepared as an account of work sponsored by an agency of the United States Government. Neither the United. States Government nor any agency thereof, nor any of their employees, makes any warranty, express or implied, or assumes any legal liability or responsibility for the accuracy, completeness, or usefulness of any information, apparatus, product, or process disclosed, or represents that its use would not infringe privately owned rights. Reference herein to any specific commercial product, process, or service by trade name, trademark, manufacturer, or otherwise does not necessarily constitute or imply its endorsement, recommendation, or favoring by the United States Government or any agency thereof. The views and opinions of authors expressed herein do not necessarily state or reflect those of the United States Government or any agency thereof.

This report has been reproduced directly from the best available copy.

Available to DOE and DOE contractors from the Office of Scientific and Technical Information, P.O. Box 62, Oak Ridge, TN 37831; prices available from (615) 576-8401.

Available to the public from the National Technical Information Service, U.S. Department of Commerce, 5285 Port Royal Road, Springfield, VA 22161. 


\section{DISCLAIMER}

Portions of this document may be illegible in electronic image products. Images are produced from the best available original document. 
WSRC-TR-99-00305, Revision 0 .

APPROVALS

Dem es EBurfoul

Dennis F. Pickford, Author

Dis for Michael Smith

Michad E. Smith, Author

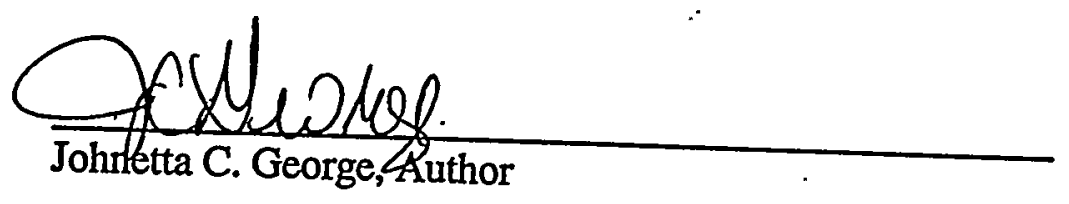

EN Aoetzabul

E. W. Holtzschefter, Technical Reviewer

$\frac{\text { Alex Conj }}{\text { A.D. Cozzi, Technical Reviewer }}$

Ewholpheuto

E. W. Holtzscheiler, Level 3 Manager

Immobilization Technology $\frac{8 / 30 / 99}{\text { Date }}$

$\frac{8 / 30 / 99}{\text { Date }}$

$\frac{8130 / 99}{\text { Date }}$

$\frac{8 / 3 i / 99}{\text { Date }}$

$\frac{8 / 30 / 99}{\text { Date }}$

$8 / 30 / 99$

Date 


\section{WSRC-TR-99-00305, Revision 0}

TTP SR1-6-WT-31

Milestone C.3-2 Annual Report on Clemson/INEEL Work

Milestone C.1-3 Status of Replacement Heater Modules for Pour Spout Heater

D. F. Bickford, D. C. Iverson, H. N. Guerrero, M. E. Smith, E. K. Hansen, J. C. George, R. P. Singer

Issue Date: August 30, 1999 
4

WSRC-TR-99-00305, Revision 0

EXECUTIVE SUMMARY 


\section{WSRC-TR-99-00305, Revision 0}

\section{TABLE OF CONTENTS}

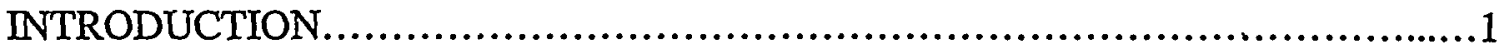

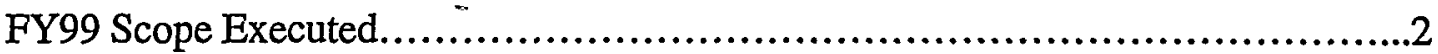

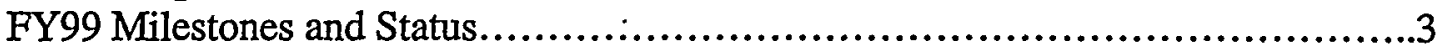

CLEMSON WORK AND STATUS OF REPLACEMENT HEATER MODULES FOR POUR SPOUT HEATER ..................................................5

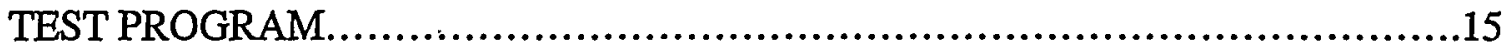

Pour Spout Tests................................................................24

Pour Spout Geometry Effects......................................................36

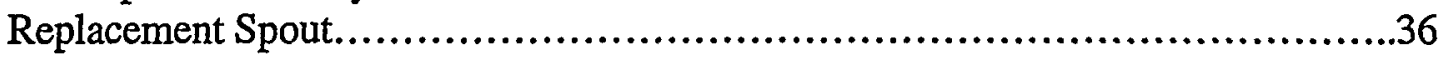

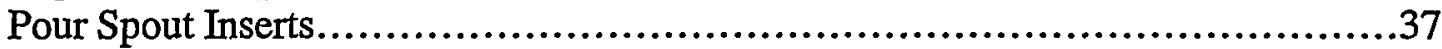

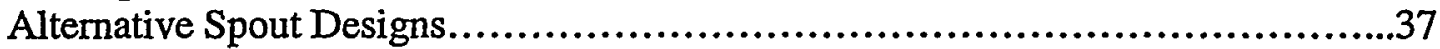

Wear \& Corrosion Tests..........................................................38

Noble Metal Behavior and Effects................................................38

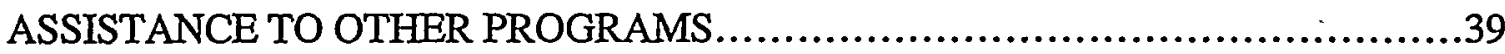

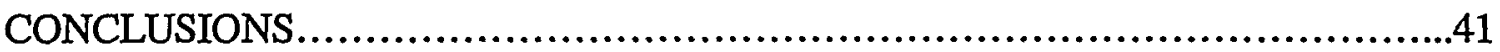

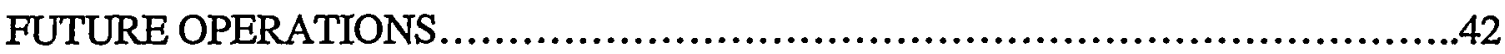

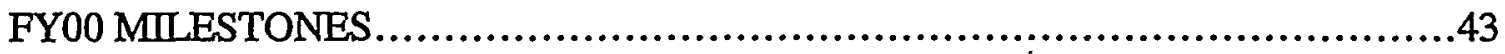

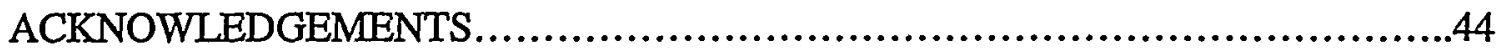

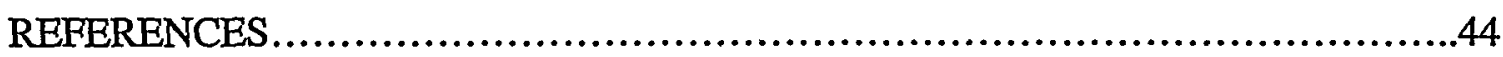

APPENDIX A Numerical Modeling of DWPF Melter Glass Pour Process...............45 


\section{WSRC-TR-99-00305, Revision 0}

\section{LIST OF ILLUSTRATIONS}

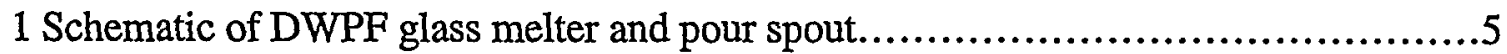

2a Schematic of melter pour spout showing removable insert.........................6

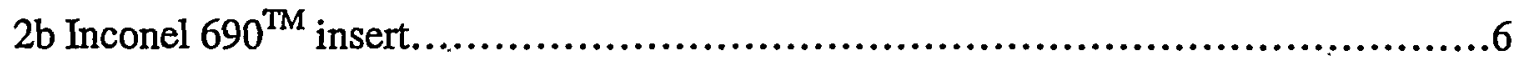

Pour spout test stand................................................................

Details of Stirred Melter..................................................................8

Pour spout images

High resolution electronic camera image looking up at $1150^{\circ} \mathrm{C}$ upper knife edge.........10

High resolution electronic camera image looking upspout at $1150^{\circ} \mathrm{C}$ showing near-as-machined condition of upper knife edge.....................................10

Insert installed in spout and at operating temperature...................................10

Replaceable insert being installed in the test spout.....................................10

Insert mounted on the insertion tool, prior to installation................................11

Top view of the replaceable insert.....................................................11

Side view of the replaceable insert..................................................11

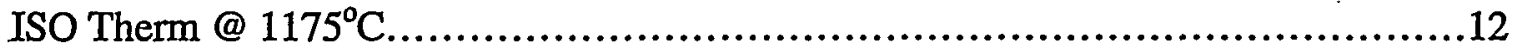

Thermal imaging viewing up the spout............................................13

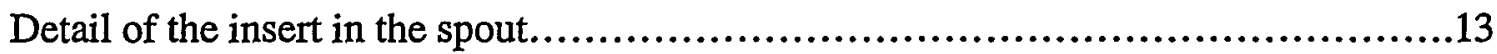

Thermal image measuring temperature of glass falling through the spout...............13

High resolution electronic image looking into the spout...............................13

Two assembled electrical brushes used to replace the supplied buss bar and connectors. 


\section{WSRC-TR-99-00305, Revision 0}

Inside of the new brush assembly showing the graphite electrical brush supported

by a copper support............................................................15

3 Glass stream behavior inside an Insert during a 7.8 pout surge $5 / 19 / 99 \ldots \ldots \ldots \ldots \ldots . .26$

4 Glass stream behavior inside an Insert at $125 \mathrm{lbs} / \mathrm{hr}$ flow and $4 \mathrm{lbs}$ surge............27

5 Glass stream behavior inside an insert at $125 \mathrm{lbs} / \mathrm{hr}$ flow and $8 \mathrm{lbs}$ surge............28

Glass stream deflections during an $8 \mathrm{lbs}$ surge at $125 \mathrm{lbs} / \mathrm{hr}$ flow:.....................29

Glass stream deflection recorded by side camera during a 3/9 lbs surge and

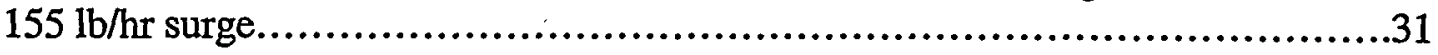

9 Glass stream behavior inside an insert at $155 \mathrm{lbs} / \mathrm{hr}$ flow and $8 \mathrm{lbs}$ surge..............32

10 Glass stream deflection as recorded by side camera during $8 \mathrm{lbs}$ surge at

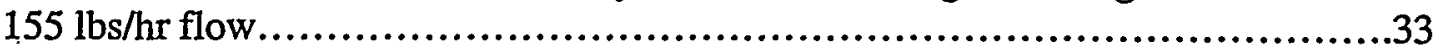

11 Glass stream behavior inside an insert at $42.2 \mathrm{lb} / \mathrm{hr}$ flow and $4 \mathrm{lbs}$ surge.............34

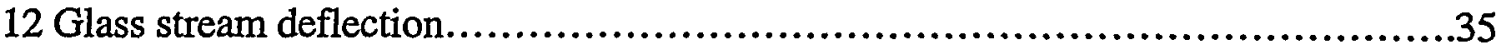

Pu Can-in Canister being filled/glass stream going into can...........................39

13 Conceptual designs of improved spout inserts....................................40

\section{Graphs}

Temperature gradient in test pout spout............................................14

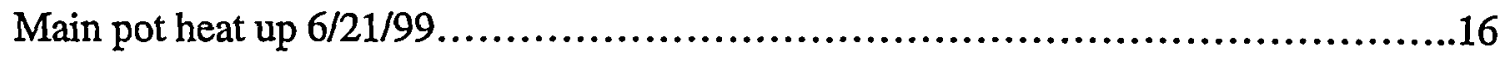

Main pot 6/21/99 - Melter primary task temperatures at steady state without joule heat.

Superheater checkout 5/17/99 - In the superheater TC1 thermocouples are adjacent to heaters and TC2 thermocouples are adjacent to the $\operatorname{tank} . \ldots \ldots \ldots \ldots \ldots \ldots \ldots \ldots \ldots . . \ldots 18$

Superheater 6/21/99 - Superheater temperatures after installation of auxiliary heaters...19

Pour Spout Temperatures 6/22/99 - Temperatures of the DWPF test Riser and Pour 


\section{WSRC-TR-99-00305, Revision 0}

Pour Spout 5/17/99 - Temperatures in the DWPF test Riser and Pour Spout, $1050^{\circ} \mathrm{C}$ setpoint.

Drain Side 6/21/99 - Temperatures of the auxiliary heaters installed to improve glass heating in the Superheater ( 5 auxiliary heaters).

Drain Side 5/17/99 - Temperatures of the auxiliary heaters installed to improve glass heating in the Superheater ( 3 auxiliary heaters). 


\title{
TTP SR1-6-WT-31
}

\section{Milestone C.3-2 Annual Report on Clemson / INEEL Melter Work}

\section{Milestone C.1-3 Status of Replacement Heater Modules for Pour Spout Heater}

\author{
D. F. Bickford, Principal Investigator, \\ D. C. Iverson, H. N. Guerrero, M. E. Smith, \\ E. K. Hansen, J. C. George, R. P. Singer \\ Westinghouse Savannah River Company \\ Savannah River Site \\ Aiken, South Carolina 29808
}

\section{Introduction}

This work is performed in collaboration with RL37WT31-C and ID77WT31-B. During the first two years of radioactive operation of the DWPF process, several areas for improvement in melter design have been identified. Due to the need for a process that allows continuous melter operation, the down time associated with disruption to melter operation and pouring has significant cost impact. The continuing scope of this task is to address performance limitations and deficiencies identified by the user. SRS will design and test several configurations of the melter pour spout and associated equipment to improve consistency of performance and recommend design improvements. SRS and PNNL will evaluate melter design improvements that will provide higher melter rates, improved temperature control and mixing to reduce the impact of spinel and noble metals deposition on melter life, improved cost per pound of glass produced, and more robust materials compatible with the Idaho acid process developed feed. SRS will address the effects of feed chemical properties (corrosive components, redox control, precursors to melter foaming, etc.). ID will integrate the Idaho design needs into this task.

Task/Subtask Summary:

The DWPF melter was designed 15 years ago. The DWPF melter has been operated non radioactively for 2 years plus radioactively for 3 years. During the time since its design technical improvements have been made by commercial melter manufacturers and DOE labs, and portions of the melter have been determined that would benefit from improvement in operating efficiency and in extending melter life. WSRC will participate in a workshop headed by PNNL evaluating currently available melting technology, and will provide assistance to INEEL in melter testing of glasses for INEEL high level waste application.

The pour spout test stand installed at Clemson Univ. in FY98 will continue operation to test alternatives to the existing DWPF pour spout. Pour spout flow, alternative spout inserts, replaceable knife edges and replaceable spout heaters will be tested. The molten glass for the Pour Spout Test Stand is a nine square foot stirred melter that was designed and constructed as a second generation DWPF prototype. The stirred melter features modular construction, with all glass contact materials made from Inconel 690 (TM). The Inconel allows the melter to be thermally cycled, permitting easy draining and repair or replacement of components such as the melting tank, glass holding tank, and pour spout. The pour spout is of a wetted tube 
design, with a flow control valve and a freeze valve. This unit was constructed in nine months time, which is four times faster than the construction of the DWPF melter.

This program is jointly funded by EM-30, SRS High Level Waste Management. In FY98 equipment valued at $\$ 2.5$ million was provided to the program by EM-30, and over $\$ 100 \mathrm{~K}$ was provided in direct program support, both in direct funding and in support from DWPF technical. In FY99 this support continued, to include providing inserts, insert design, and test monitoring, and $\$ 100 \mathrm{~K}$ in direct support.

University participation is a major component of this program. The test melter and related test components are installed and tested at Clemson University with WSRC control and monitoring. University installation and operating costs are a large fraction of total costs. In FY99 university grants and contracts were $\$ 307 \mathrm{~K}$.

\section{FY99 Scope Executed:}

PNNL, SRTC, INEEL, and WVDP evaluated current melter designs and identify the key areas for improvement, including reviews with DWPF technical and engineering staff. The performance features of existing commercial melters were evaluated both both nationally and internationally. The summary of the workshop which conducted this study is being issued by PNNL (lead laboratory fo this task). The candidate commercial melter of the high frequency induction melter type were considered to be at the point of development where systematic investigation by DOE should be conducted: A unit is in low level waste operation in Russia, and is scheduled for High Level Waste immobilization in France. These systems offer cost incentives associated with waste volume reduction because of higher than current operating temperatures. The existing site tasks were assisted to improve the feed and melter chemistry to improve melt rate, reduce corrosion, and reduce foaming-demonstrate in a melter. For application to Idaho HAW, the glass chemistry work in TFA task 98059 was integrated with this task to ensure materials compatibility and to define performance requirements.

Task C.1. SRTC and Clemson continued testing of melter pour spout improvements. The results of this task support the SRS site efforts to rapidly verify design modification that can be retrofitted to Melter 3 prior to installation in DWPF. Operational testing of the stirring feature of the melter being used to achieve high pour rates for pour spout design was conducted. Several safety features of the test unit were improved prior to testing. Manpower and costs to improve safe operations caused operating delays, and reduced the amount of work performed. Melters were prepared to test features and chemistry identified in Tasks C.2. and C.3.

Task C.2. The joint SRTC/PNNL team evaluated commercially available designs (national and international) for application in the DWPF and at Idaho (priority was given to improving current DWPF operations). The results of this evaluation are being integrated with FIU work and Task C.1 and in TFA Technical Response 98059. The facilities established in the previous phases of this task or associated with other DOE development efforts were maximized to minimize costs.

Task C.3. The DWPF is operating currently with a sludge only feed which is expected to transition to "coupled" operation where the predominantly Cs and some TRUs are introduced to the melter feed. Idaho will operate an acid flowsheet that is high in nitrate, alkali, and possibly phosphates. The melter feed chemistry is affected by the feed conditioning (for DWPF:level of washing, the composition of the Cs bearing stream, levels of carbonate in-growth to the sludge, and the extent of redox adjustment that occurs in feed preparation, for Idaho: the extent of denitration occurring in pretreatment, the chemical components added during pretreatment, high $\mathrm{Zr}$ and other components that may be difficult to incorporate into the glass). This task has been coordinated with existing process flowsheets, facility analytical capabilities, off- 
gas safety constraints, and melter capabilities. This year's activiites focussed primarily on setting up redox testing apparatus, and assisting with batching and melting of INEEL surrogate wastes.

The specific activities for FY99 included the start of testing of a DWPF Cs bearing stream, preliminary evaluation of redox requirements for both DWPF and Idaho, and support of initial testing with higher $\mathrm{Zr}$ compositions. (Note this work was coordinated with task 98059 both for the additional $\mathrm{Zr}$ as well as the impact on phase separation).

\section{FY99 Milestones and Status:}

C.1-1 Issue a test plan for the Clemson large scale testing $\quad 1 / 31 / 99$ [OO] This test plan will provide direction to the testing to be performed by Clemson and SRTC to support the melter pour spout design improvements.

Status: Complete. This included the drafting of operating procedures for Clemson, including checklists, inspections and response to abnormal conditions. The procedures have been accepted by Clemson and included in facility operating procedures.

C.1-2 Functional test of pour spout insert and knife edge $5 / 30 / 99$ [HQ] Designs being developed by SRS and input from the TFA team will set up at Clemson University and tested. The performance will be documented to support the development of design changes for melters 2 and 3 for DWPF.

Status: Compete. Report WSRC-TR-99-00232 was issued reporting the results of the testing.

C.1-3 Replacement heater modules for spout riser $8 / 30 / 99$ [OO] Status report on progress in developing and testing techniques that will allow replacement of the heater modules in subsequent pour spouts. If a design can be developed to retrofit the existing replacement melter prior to installation in DWPF, that will be documented in this report.

Status: Complete. His report contains the summarized results of the study.

C.2-1 Issue report on review of melter technology [PNNL lead]

6/30/99 [CNTR] A technology exchange will be conducted to review both national and international technology particularly as it relates to operational experience in DWPF and West Valley. Expected participants include PNNL, SRTC, DWPF users, and West Valley. A report summarizing the meeting will be issued.

Status: SRTC portion complete. SRTC and DWPF Production and Technical personnel participated in a workshop lead by PNNL and SRTC. PNNL will issue the report documenting the content and findings of the workshop.

C.2-2 Report Summarizing the Melter Technology review with recommendation for SRS and Idaho (PNNL lead)

9/30/99 [OO]

The annual report will include data generated in the workshop as well as the literature and technology review. Test results from the Clemson University testing will also be incorporated as it relates to design improvements relevant to Savannah River and Idaho. 
Status: SRTC portion complete. SRTC has recommended testng for Idaho in the EnVitCo EV-16 melter at Clemson, and further study of the high frequency induction melter systems available. Design improvements relative to Savannh River are included in this report.

C 3-1 Issue report providing input to the INEEL test plan for scoping melter tests [SRTC lead]

$4 / 30 / 99[\mathrm{OO}]$

This plan will include key test parameters for Idaho formulations and design requirements based on previous TFA and site supported work. Results from the formulation work shop should be included (98059).

Status: Complete. SRTC provided INEEL with a format for operations at Clemson University, and participated in the final drafting process for two melter runs, including preparation and operating support. INEEL issues the final test plan.

C.3-2 Issue annual report on Clemson/INEEL melter work [Idaho lead] 9/30/99 [OO] This report will summarize the work at both Clemson and INEEL evaluating melter performance requirements. The report will be joint with PNNL and SRTC.

Status: Complete. This report contains the results with potential impact on Savannah River operations. SRTC work impacting INEEL operations is covered by INEEL's report, which includes SRTC input. 


\section{Clemson Work and Status on Replacement Heater Modules for Pour Spout Heater}

During the first two years of radioactive operation of the Defense Waste Processing Facility (DWPF) process, several areas for improvement in melter design were identified [1]. Due to the need for a process that allows continuous melter operation, the down time associated with disruption to melter operation and pouring has significant cost impact. A major objective of this task is to address performance limitations and deficiencies identified by the user (DWPF) [2]. The actual testing is being performed at Clemson University's Environmental Technologies Laboratory (CETL) using a full DWPF size stirred melter. The task installed, tested and operated the melter, including design, construction and operation of a full scale

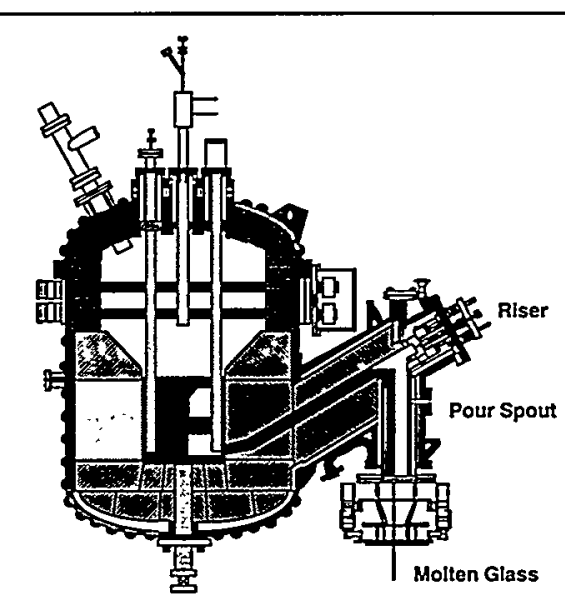

Figure 1. Schematic of the DWPF glass melter and pour spout. simulated DWPF riser and pour spout.

In preparation for vitrification, the radioactive feed is chemically processed using various acids. Borosilicate frit is blended with the processed feed and then continuously fed under normal operating conditions to the melter (Figure 1). The melt pool temperature is maintained at approximately $1150^{\circ} \mathrm{C}$. Pouring rates are nominally $82 \mathrm{keg}$ per hour $(180 \mathrm{lbs} / \mathrm{hr})$.

Normally molten glass flows over the riser and down the side of the pour spout closest to the melter. Two knife-edges are machined into the pour spout to provide a release point for the molten glass stream. The Inconel $690^{\mathrm{TM}}$ pour spout is not removable and therefore, failure of this component would result in the removal of the entire melter. External heaters are used to keep this region of the pour spout between 1000 and $1150^{\circ} \mathrm{C}$. The molten glass free falls from the knife-edge into the stainless canister below. In the DWPF as the knife-edges degraded the glass stream began to waver and wick down the side of the pour spout resulting in partial blockage in the bellows just above the canister. Glass that had built up on the knifeedges was initially removed by remote mechanical cleaning. However, the pour stream instability problem worsened. Thus, a removable Inconel $690^{\mathrm{TM}}$ insert containing a new knife-edge was developed and placed into the pour spout (Figure 2a). An Inconel $690^{\mathrm{TM}}$ retaining ring with three Inconel MA 758 pins were used to hold the insert in the pour spout (Figure 2b). Special tools were developed to remotely install this component into the pour spout between the upper and lower knife-edges. The upper knife-edge was used as a sealing surface. The insert was a key element in resolving the pour stream instability problems thus restoring glass production to design rates. 


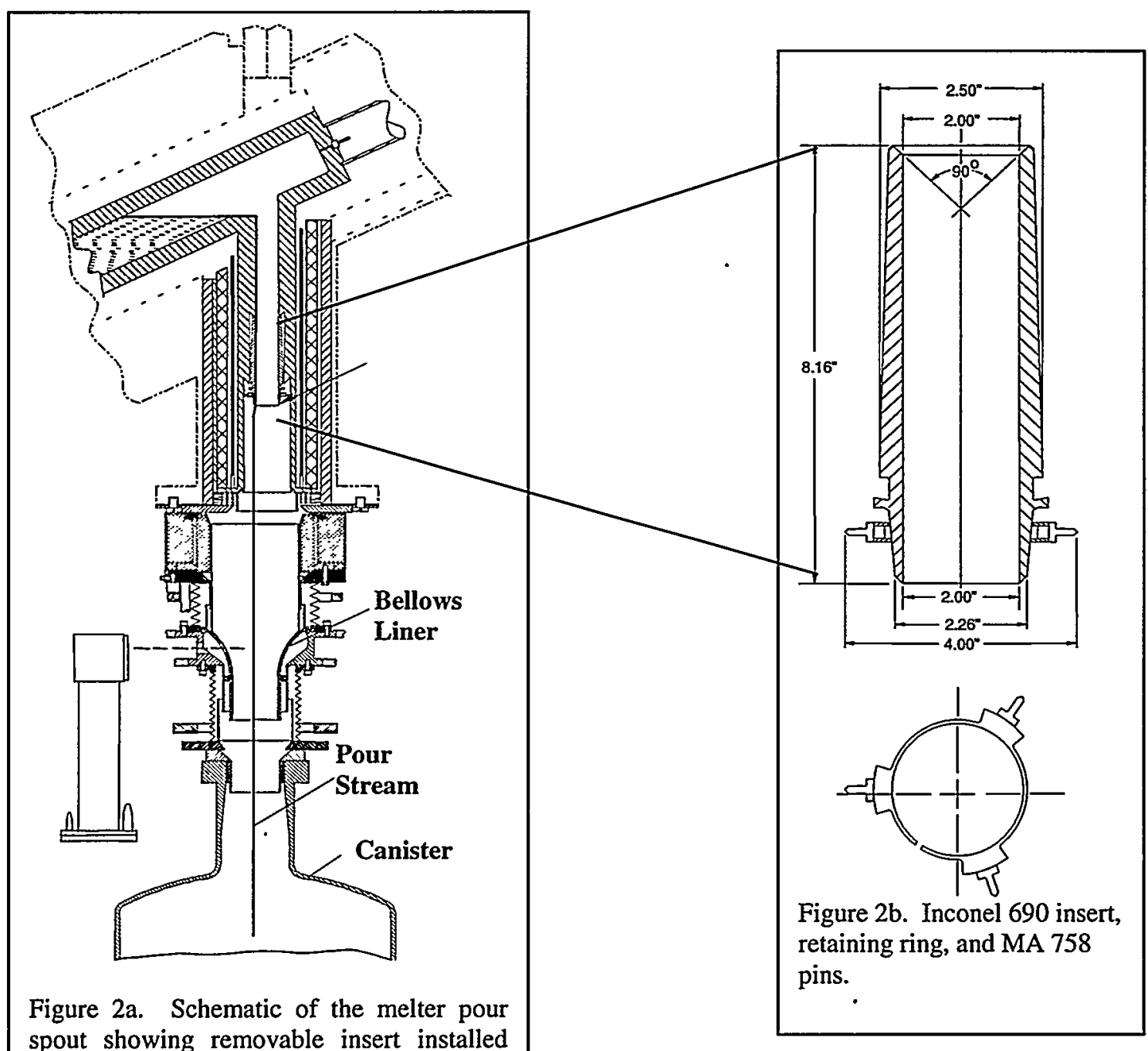
between upper and lower knife's edges. 


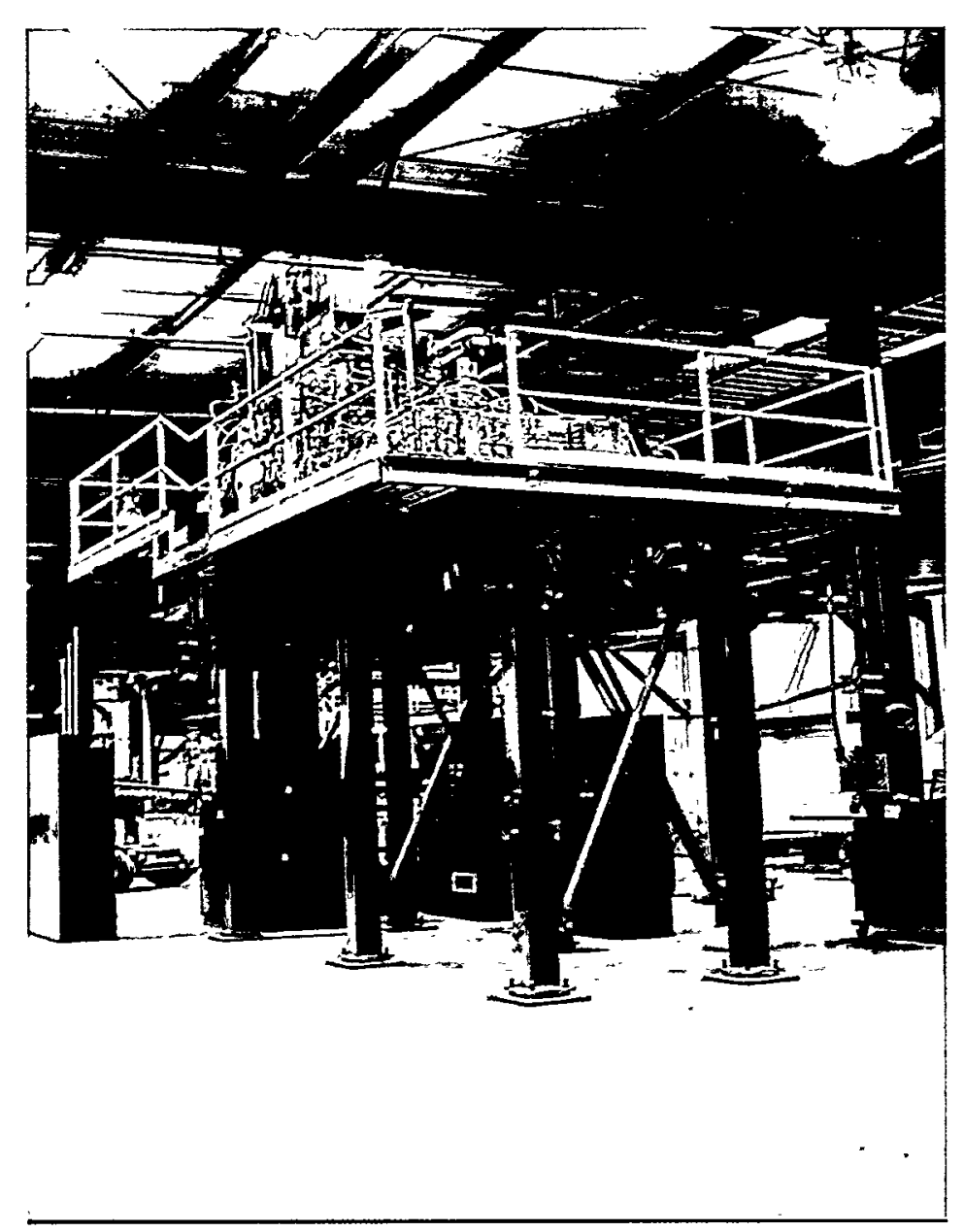

Photo \#1--The Pour Spout Test Stand

\section{DWPF Riser/Pour Spout Design}

To conduct the necessary tests, a DWPF Pour Spout Test stand has been installed below the Superheater pour valve of the stirred melter.

The Riser section of the Riser/Pour Spout collects melted glass from the Melting Chamber and conducts it up an incline to the Pour Spout Section. The Pour Spout Section glass flows down into the canister, where the glass cools and hardens.

The major design objective of the Riser/Pour Spout is to fail safe, i.e., it is better to have operating failure modes which retain the glass in the melter than to have uncontrolled leakage of glass out of the melter. The pour control stream operated on the basis that a failure in the control equipment will stop the glass flow, rather than over filling the can. This is accomplished by sensing the plenum pressure (gas pressure) in the top of the melt chamber, and pulling a partial vacuum on the canisters. This partial vacuum draws glass up the riser, where it falls over into the pour section. The intention is then for the glass to separate from the pour spout metal at a knife-edge cut into the pour spout, and to fall directly into the can. The Normal Disengagement Point is the point of the knife-edge closest to the Melter Chamber, i.e., directly above the center point of the canister. The bellows section is replaceable and contains a Bellows Liner which is intended to guide stray glass back to the canister. The Bellows Liner is relatively simple to clean in place or 
remove if it becomes damaged. After passing through the Bellows Liner the glass drops through the Canister Throat Protector into the canister. The Throat Protector keeps the underlying metal clean to assure a quality canister closure weld.

The Riser Section contains a sealed-at-the-bottom annulus of Inconel $690^{\mathrm{TM}}$ (Inconel $690^{\mathrm{TM}}$ is the only nonplatinum group metal which can withstand exposure to molten glass and air for the required time of 2-8 years). Inside of the annulus are electrically insulating ceramic tubes and a serpentine shaped electrical heater element machined from a plate of Inconel $690^{\mathrm{rm}}$. The Riser section has similar construction. The heater elements are necessary to control the viscosity of the glass. The heaters are also necessary to keep the glass above its liquidus temperature. Staying above the liquidus temperature is necessary to prevent material dissolved in the glass from coming out as crystalline deposits which can plug the passages or disturb the normal flow of the glass. Crystalline spinels $\left[(\mathrm{Ni}, \mathrm{Fe})\left(\mathrm{Fe}, \mathrm{Cr}_{3} \mathrm{O}_{4}\right)\right]$ have been found in the upper section of the DWPF pour spout, indicating that this section is not always above the liquidus. The current Riser/Pour Spout design has temperature gradients resulting from end effects of the serpentine heaters, and high thermal losses where the Riser/Pour Spout are joined.

\section{Full-Scale DWPF Melter Pour Spout Test Stand}

The full-scale DWPF Stirred Melter Pour spout Test Stand was installed at Clemson University via a South Carolina Research and Educational Foundation (SCUREF) contract. It is located at the Clemson Environmental Technologies Laboratory (CETL). The stirred melter has a full-scale DWPF riser and pour spout attached to it to allow for glass pour rates equal to or greater than the DWPF Melter. This melter is the only pilot melter available to SRS which can give the high melt rates required.

Photo \#2--Details of the Stirred Melter showing the primary melt chamber and the superheater

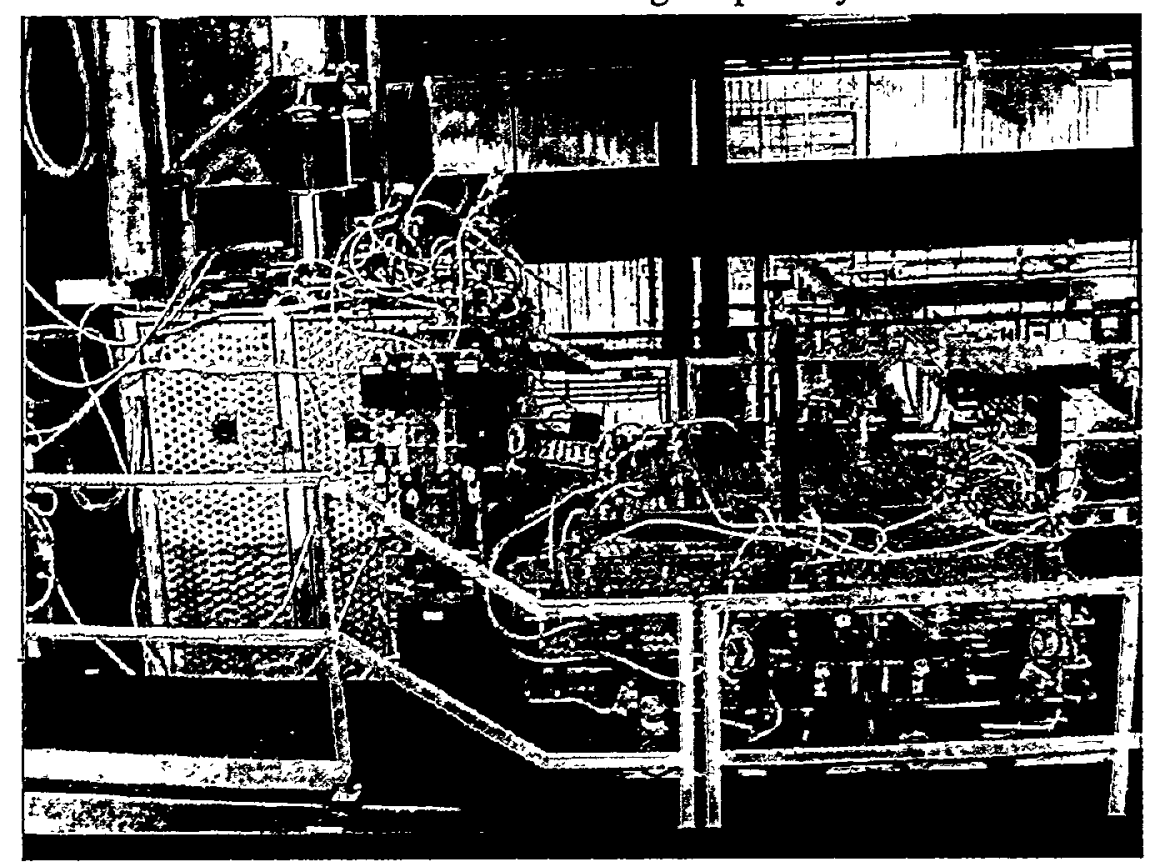

The melter has two main sections. The glass melting occurs in the primary pot. This pot is made out of Inconel $690^{\mathrm{TM}}$ and acts as one of the electrodes. It is a three foot by three foot container five feet tall. An Inconel $690^{\mathrm{TM}}$ agitator is inserted into the glass pool and rotates up to $450 \mathrm{rpm}$. Agitation forces the unmelted feed down into the $1050^{\circ} \mathrm{C}$ melt pool, thereby increasing the contact area between the glass and the feed and thus greatly increasing the melt rate. Higher temperatures are possible but are limited by various means because of uncertainties caused by possible thermal creep of the primary pot. The agitator is 
the second electrode. The glass is heated by passing current through the glass (joule heating) via these two electrodes (melt pot and agitator). External heaters are also in place to aid in the heatup of the melter and to heat the vapor space for a higher melt rate.

Due to the need to ensure glass durability and provide complete liberation of bubbles from HLW glass to preclude a porous glass product, the melter was designed to deliver glass from the primary pot to a Superheater operated at $1150^{\circ} \mathrm{C}$ (with a glass residence time of a least 4 hours). The Superheater, made of Inconel $690^{\mathrm{TM}}$ as well, is externally heated and can be operated at this higher temperature because of the smaller height (six inches) and the overall shape of the Superheater. These two factors minimize the mechanical loads on the Inconel $690^{\mathrm{TM}}$ in the Superheater.

The design features incorporated into the DWPF Stirred Melter are based on the premise that 1) the glass making process and particularly any glass contact mechanisms will be demonstrated and 2) remoteability features requiring only design (with no experimentation required to verify the design) will be demonstrated. All of these features may not be needed for the pour tests, but are given below to allow for a better understanding of the test stand:

- The design melt rate is 240 pounds per hour (pph) for slurry feeding at 40 weight percent solids (pour rates may be more that twice this for some test),

- Inconel $690^{\mathrm{TM}}$ is the reference material of construction for all glass contact areas,

- the distance between the main pot pour valve and the superheater drain valve is prototypic of the existing DWPF Melter design, (the relative elevation difference is not prototypic),

- the superheater is designed to provide a glass residence time of 4 hours at $1150^{\circ} \mathrm{C}$ to meet the glass durability requirements,

- the melter cooling system is designed to provide melter surface temperatures less than $50^{\circ} \mathrm{C}$ to match the existing DWPF Melter design criteria,

- the agitator shaft changer for "remote" removal of the agitator was included,

- the melter is designed to facilitate maintenance/replacement of either the primary melter or the superheater because the superheater can be displaced 34 inches (while at operating temperature) to allow the primary melter or the superheater to be taken out of service, and

- due to cost constraints, the melter is not designed for remote removal of the melter pot.

A full-scale DWPF riser and pour spout is heated with external resistance heaters. Temperatures are monitored by multiple thermocouples. Glass is poured out of this superheater pour valve and into the riser/pour spout at rates equal to or exceeding the nominal DWPF rate of $240 \mathrm{pph}$. A canister will be located below the pour spout to collect the molten glass. This unit functions as the molten glass supply, flow control and temperature control. Added to the Superheater is a riser and pour spout with the same internal dimensions as the DWPF riser and pour spout. This full size riser and pour spout have observation ports to allow viewing of testing under realistic DWPF conditions. The melter feed is glass cullet from DWPF cold runs or large scale pilot tests at TNX. Some of the glass will be from runs which had noble metals in the feed. This glass is crushed and reused as melter feed. A wet off-gas system will not be required, although the melter off-gas is vented to the existing exhaust system at the CETL.

The various heater zones on the melter are controlled by Watlow ${ }^{\mathrm{TM}}$ controllers. These controllers have dual thermocouple inputs. If the primary thermocouple fails, the secondary thermocouple is used. The controllers can be run in manual or automatic (temperature setpoint mode). The controllers can be set to alarm for out of specification temperatures and programmed to limit the percent output allowed, to prevent overheating of the various portions of the melter and superheater. The controllers also have the capability of being remotely controlled (setpoint changes), although this is not planned for work at Clemson. A monitor is available which can be used to view the various melter parameters. 
Installation and checkout of the stirred melter and the pour spout are complete. This report discusses the outline of that program and a preliminary analysis of the results of spout testing.

The following four pages show pictures of the pour spout, the insert and the installation images of the pour spout.
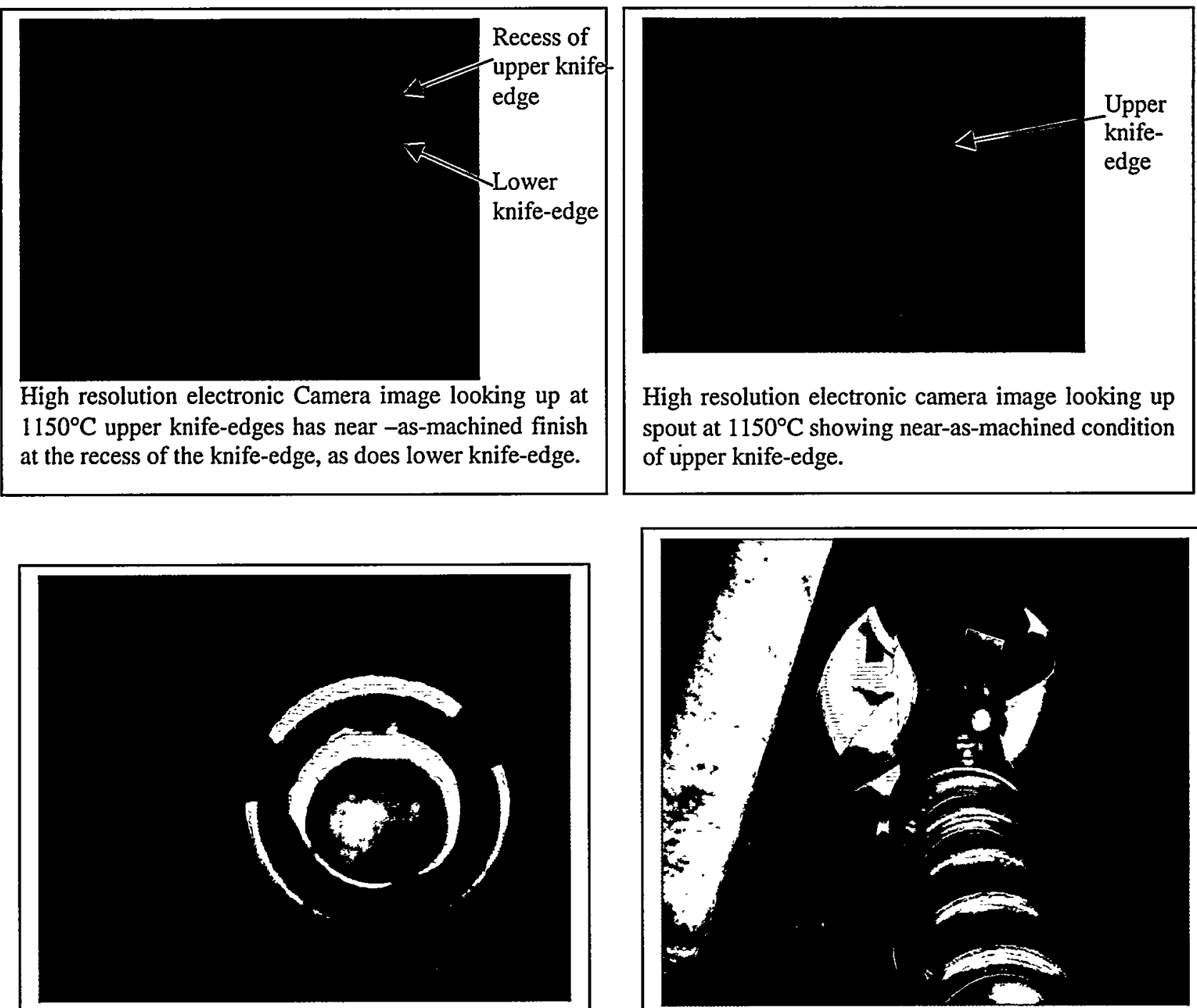

Insert installed in spout and at operating temperature. Note accumulated glass in the insert, and that the insert is off center.

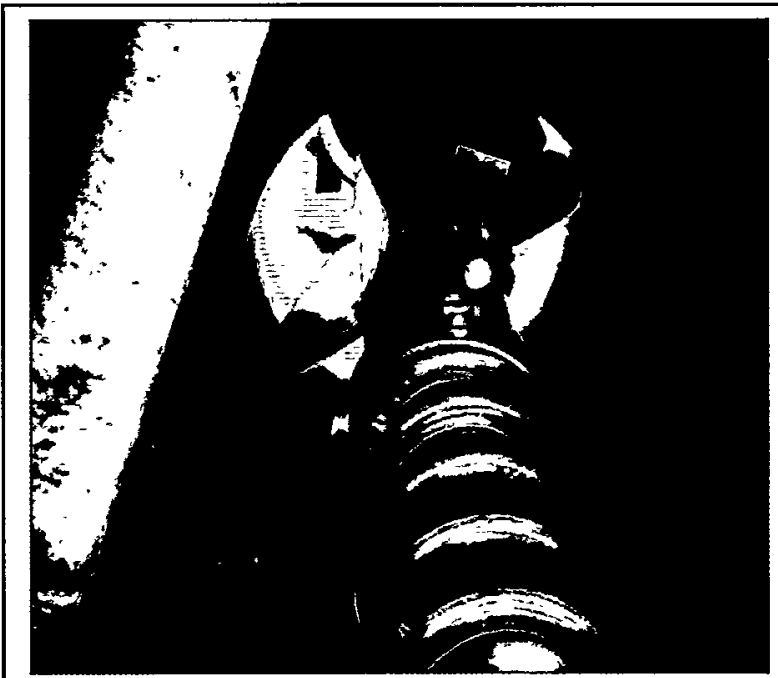

Replaceable insert being installed in the test spout 


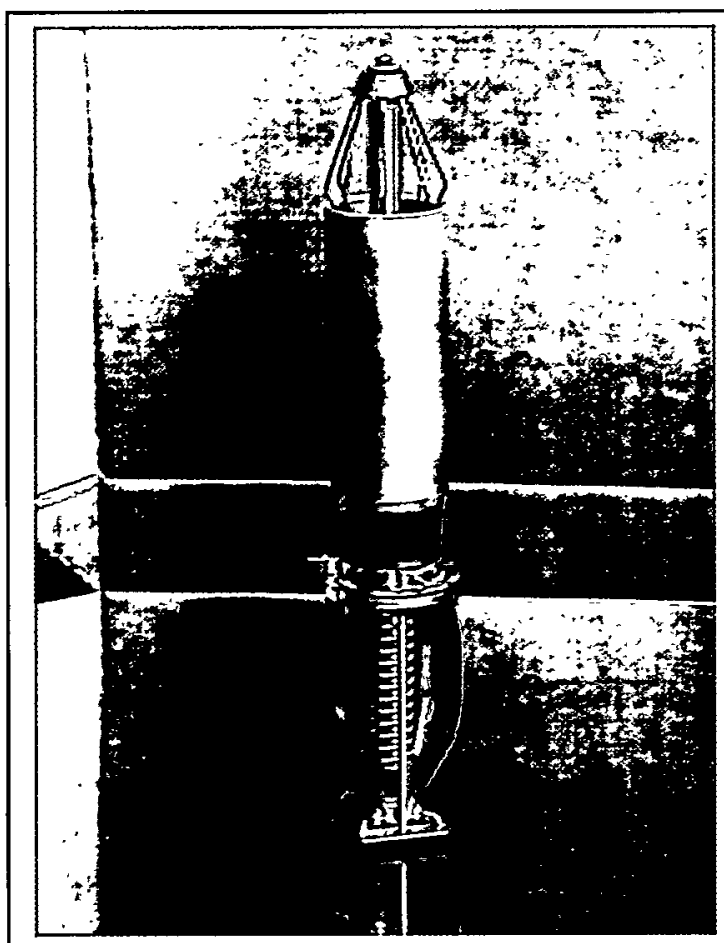

The insert mounted on the insertion tool, prior to installation

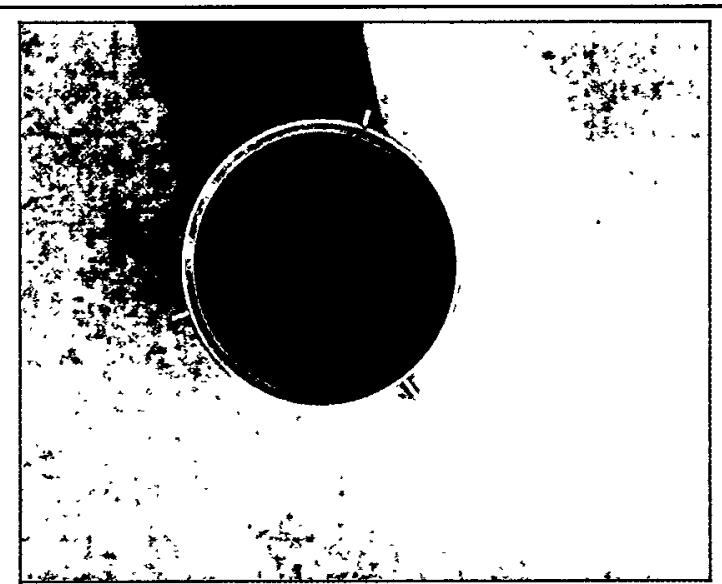

Top view of the replaceable insert

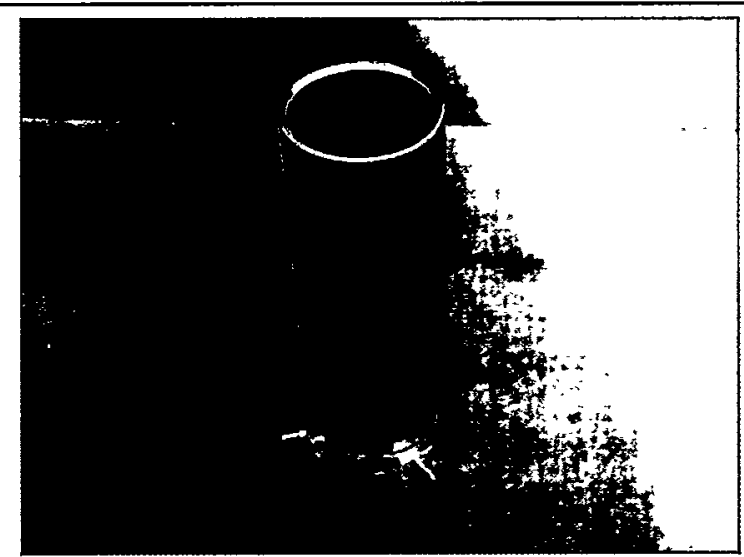

Side view of the replaceable insert 


\section{ISO Therm @ $\mathbf{1 1 7 5}^{\circ} \mathrm{C}$}

\section{$1179^{\circ} \mathrm{C}$}

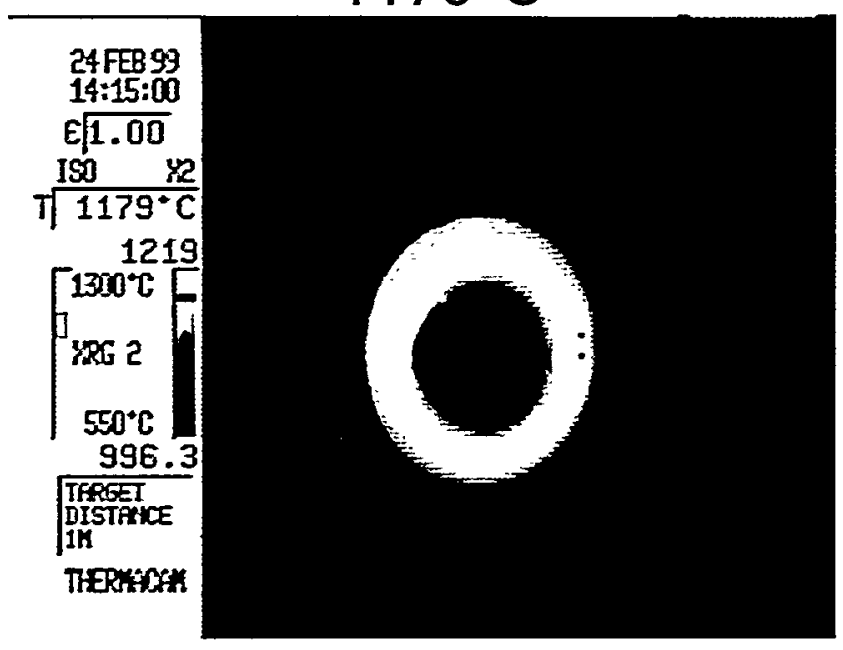

\section{$1153^{\circ} \mathrm{C}$}

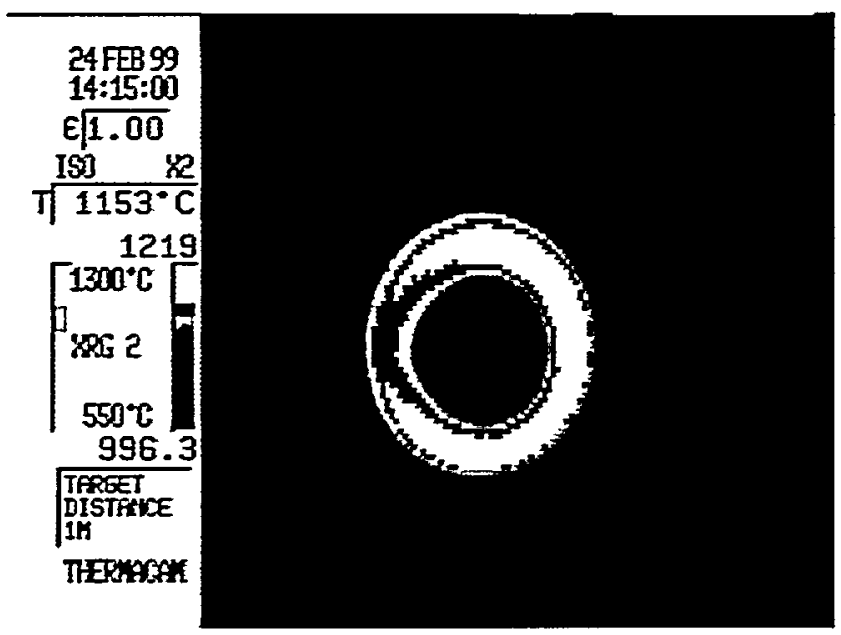

\section{$1106^{\circ} \mathrm{C}$}

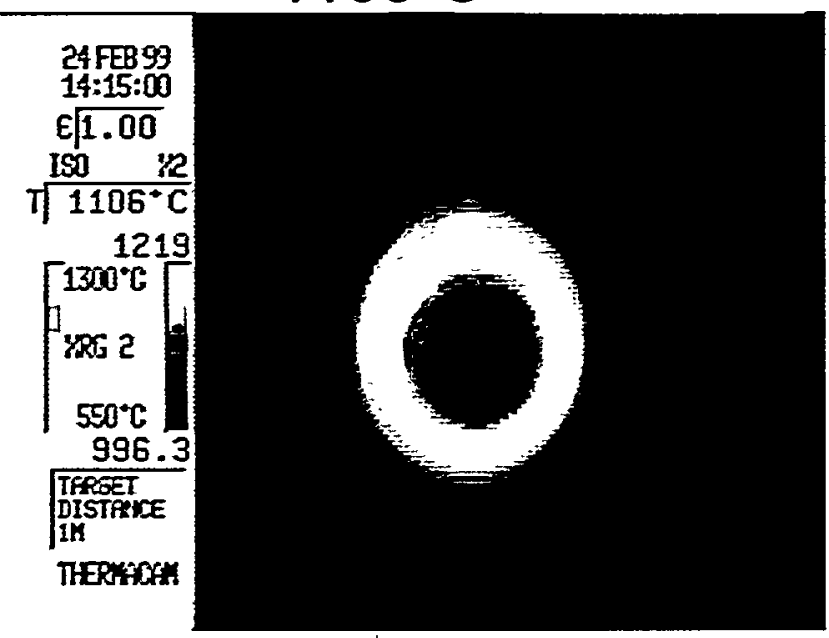

$1082^{\circ} \mathrm{C}$

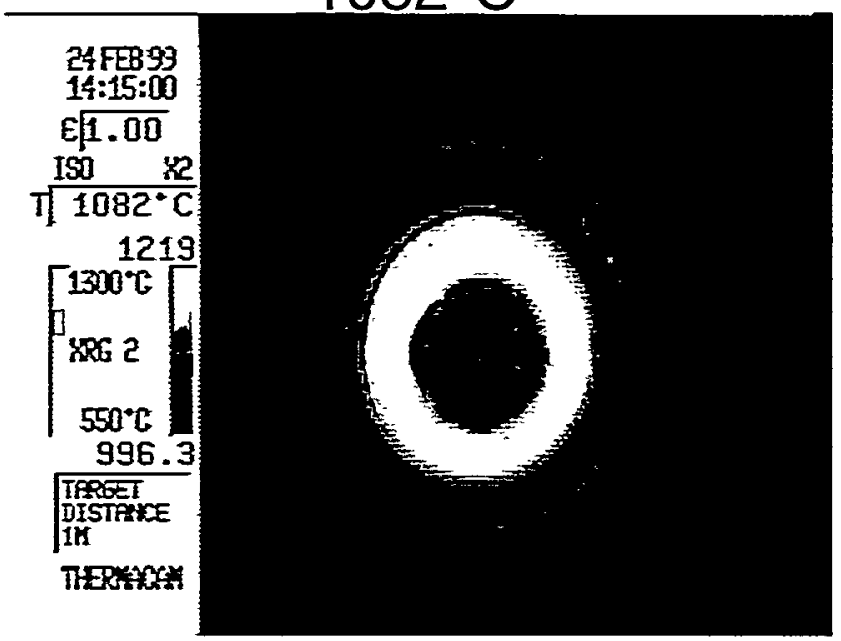

$1049^{\circ} \mathrm{C}$

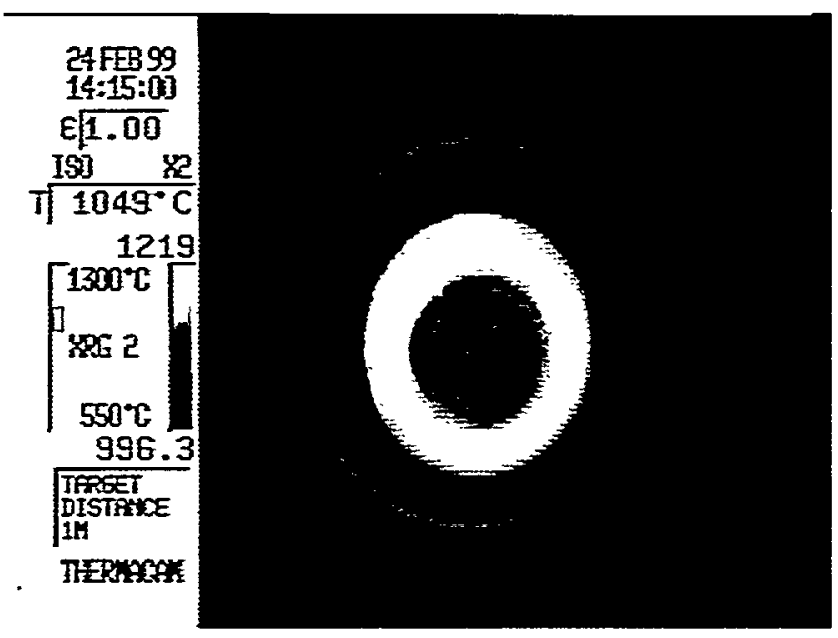

Temperature gradients in pour spout:

False color thermal images of the pour spout at operating temperatures, without the insert. The color scale on each picture indicates the temperature range. The region of the picture shown in black is at temperature $T$. Note uniformity of temperature around the circumference, and high operating temperate at the wall of the spout. The apparent low temperature at the top of the spout (center of picture) is caused by observing through a viewing port. 


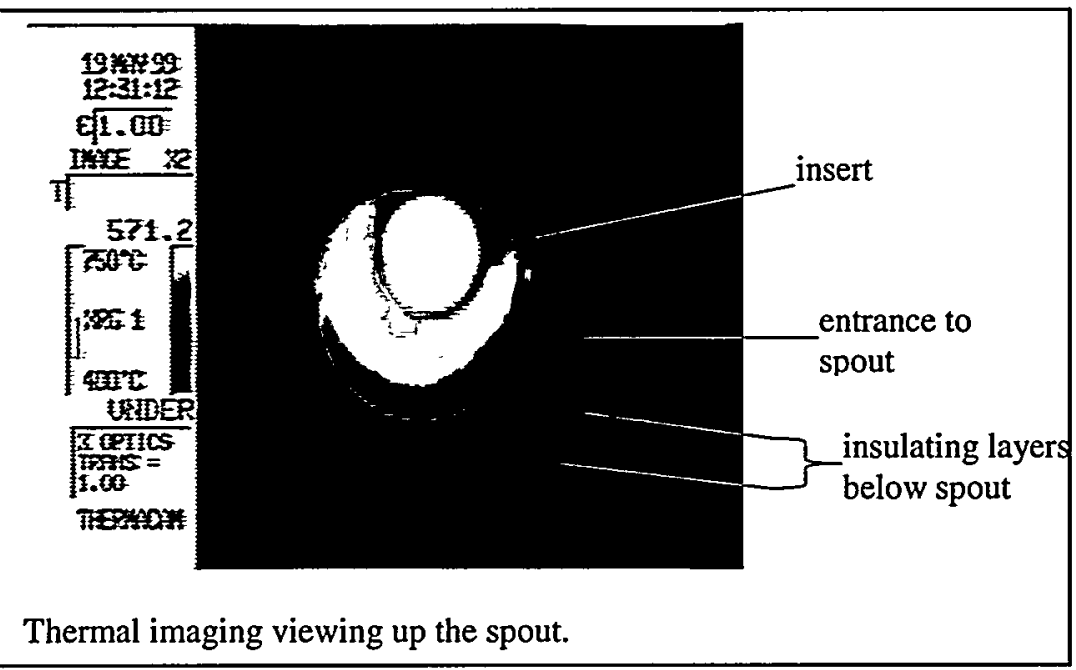

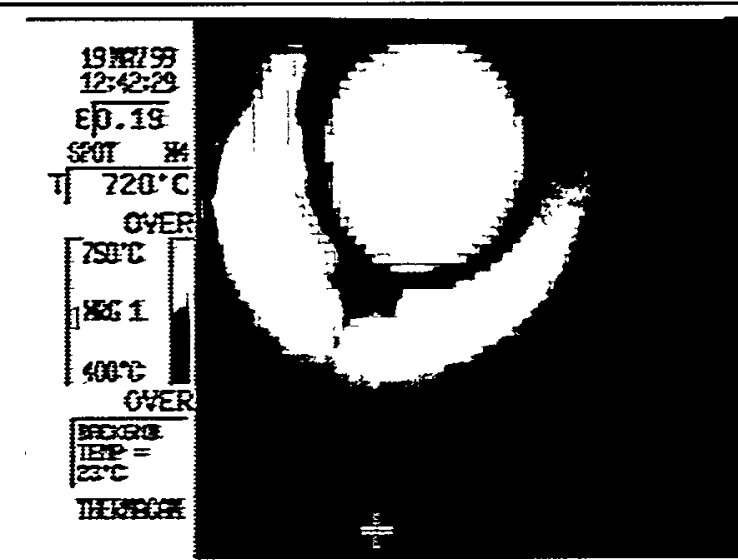

Detail of the insert in the spout.

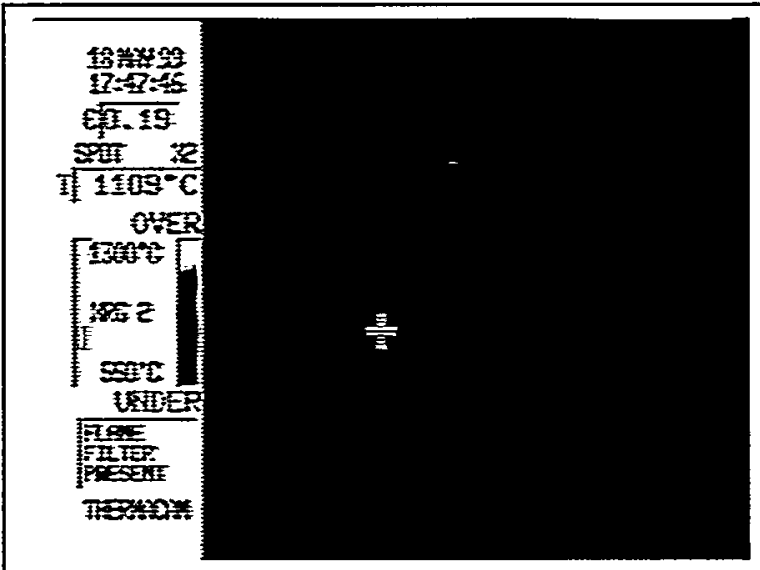

Thermal image measuring temperature of glass falling through the spout.

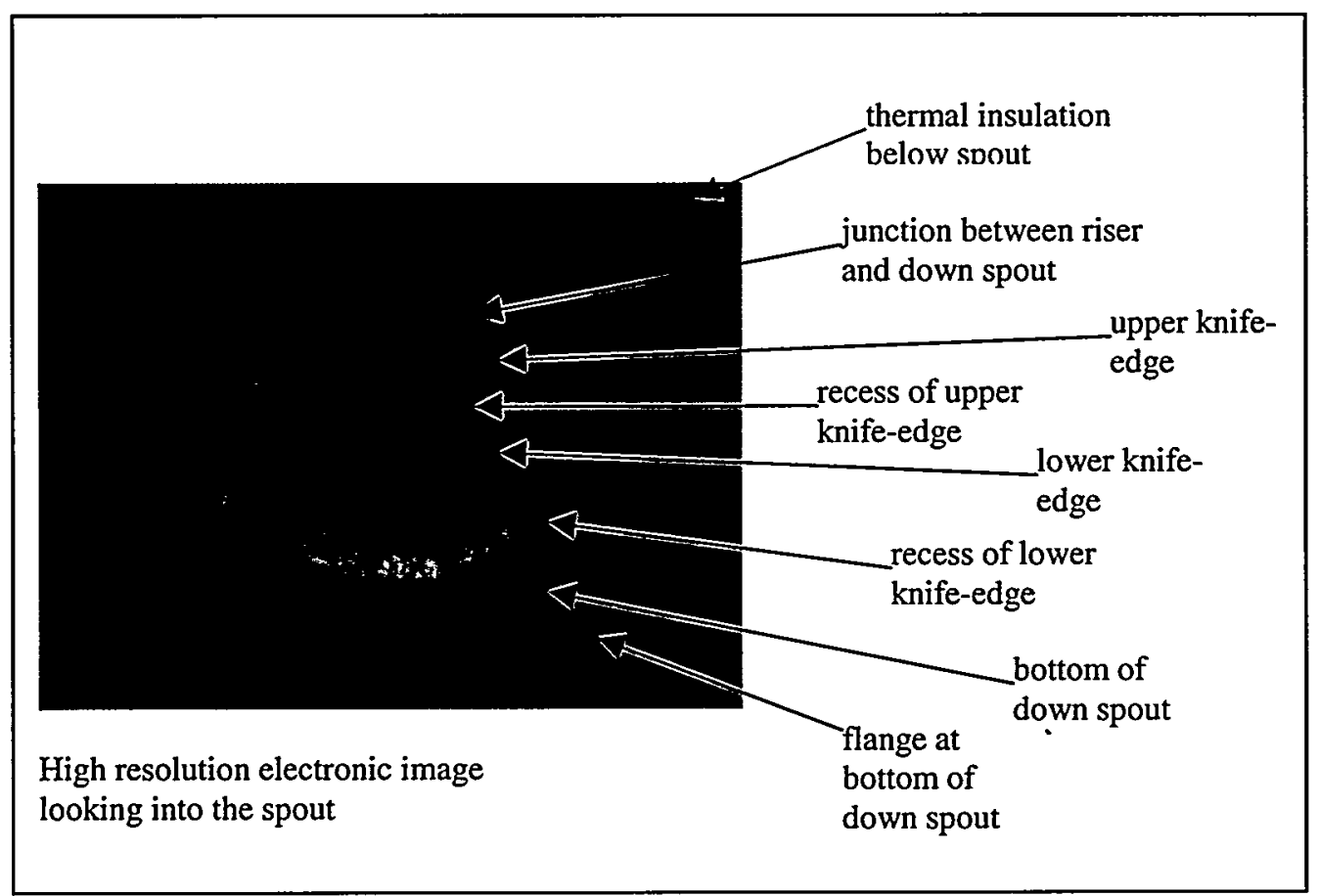


Graph 1 is a plot of the temperature readings taken by inserting a thermocouple up the spout, and contacting it against the spout sidewall. The data with a 4 inch diameter hole corresponds to normal DWPF operations, where an insulated ring with a 4 inch diameter hole at the bottom of the spout helps to retain heat. The test spout is divided into heater zones with one heater starting at 4 inches from the bottom flange, and extending to the lower knife-edge. A second zone begins at the lower knife-edge, and extends to the upper knife-edge. A third zone goes from the top knife-edge to the transition from the riser. A fourth zone maintains the temperature of the transition region. The temperatures of the different zones were set at the measured temperatures of the DWPF, and allowed to equilibrate. The power required to maintain these temperatures was $3.45 \mathrm{kw}$, including the transition region. In the second data set; the same temperature settings were maintained for the zones, but the diameter of the hole in the insulation at the bottom of the spout was reduced to 2 inches. In this case the power consumption in the first and third zones, which actually reduced the temperature at the bottom of the spout. Future tests will be conducted with input power settings, to determine what localized power is required to maintain uniform termperatures.

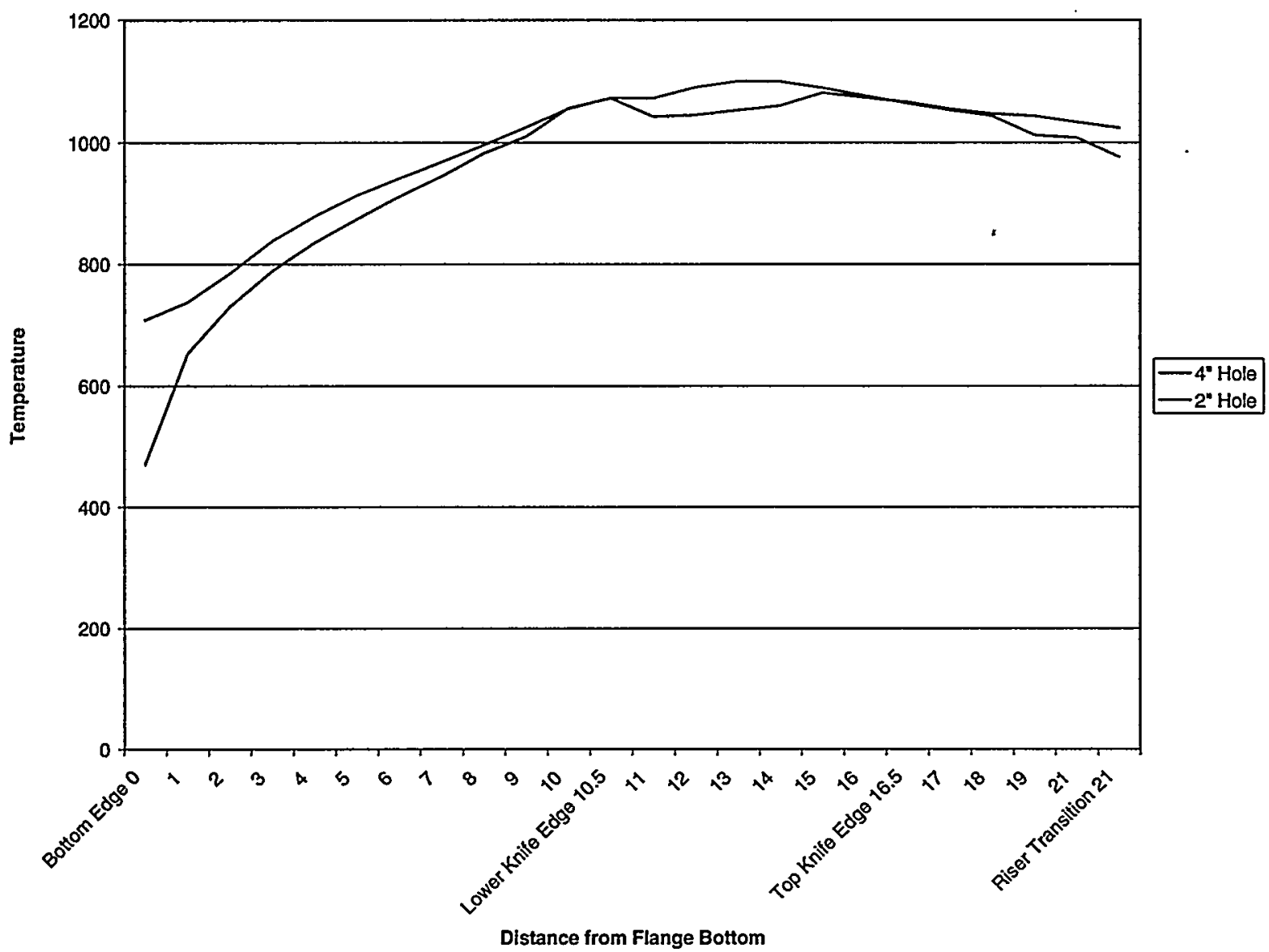




\section{TEST PROGRAM}

A comprehensive test program is being performed with the objective of improving operability issues by evaluating alternative critical component designs. Testing will be conducted on spout and glass drain valves. Actual test sequence depends upon priorities established by DWPF.

- General operability of Stirred Melter, agitator wear and sealing issues

This task is partly complete. The Stirred melter is fully operational, but has limited operating time. Most of the Stirred Melter design operated very well. However, based on glass volume the melter is a $27 \mathrm{X}$ scale up of the largest prototype tested (3X linear scale up factor). Therefore several components required modification or replacement, including buss bars and electrical brushes (see pictures below) carrying electrical current to the agitator, grounding and ground fault interruption equipment, heaters to the Superheater (hot glass hold tank), Superheater pour spout, and glass level detection.

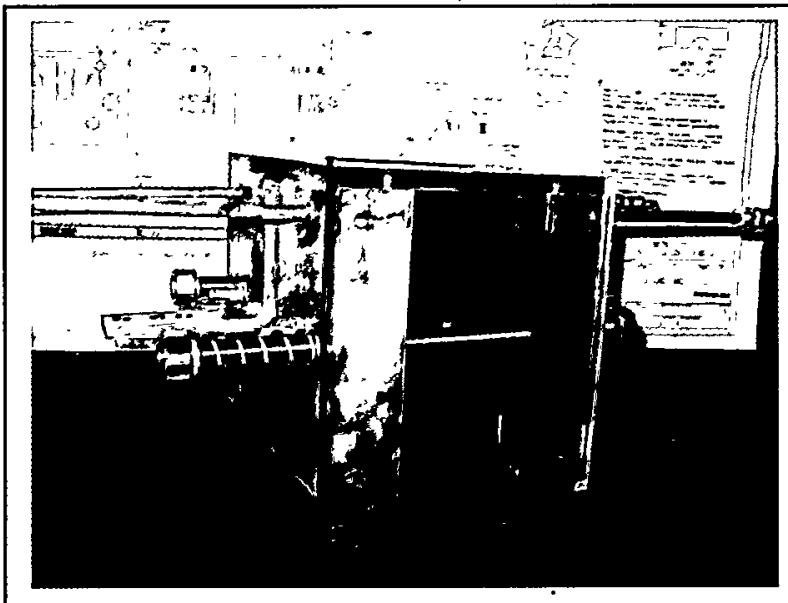

The two assembled electrical brushes used to replace the supplied buss bar and connectors.

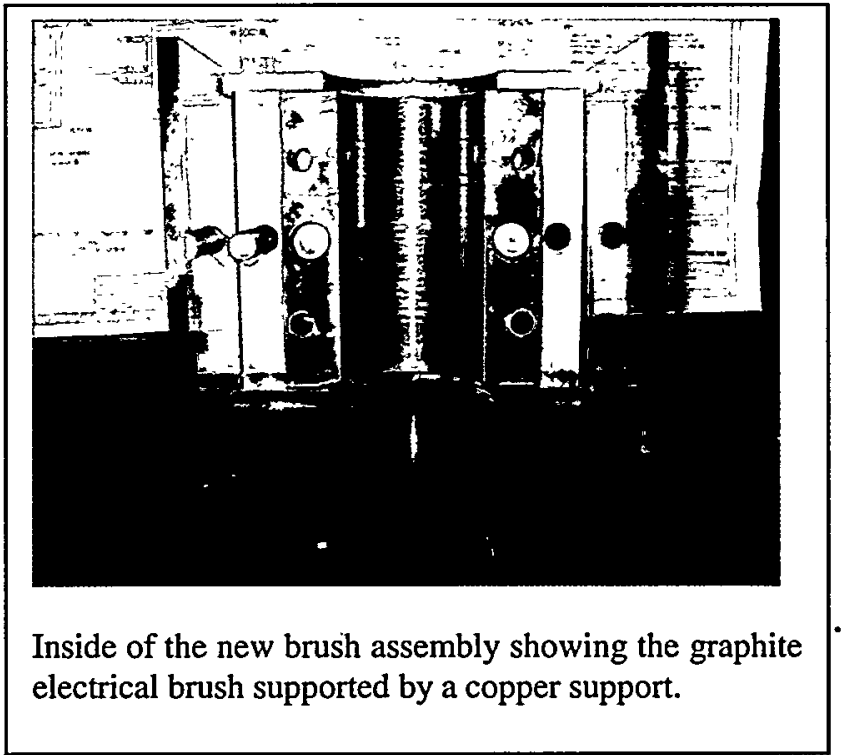

- Startup, hold and drain testing of Stirred Melter, with operating procedures

All required operating procedures are approved. The stirred melter has been through startup testing. As constructed, the main melting tank (Primary Tank) and the Superheater are heated with resistance heaters. The Primary Tank heaters are sufficient to heat the tank and glass to a temperature where joule heating of the glass is effective. However, the Superheater power was inadequate as supplied to achieve the required glass holding temperature of $1150^{\circ} \mathrm{C}$. Additional heaters were added under the tank and beside the Superheater drain and pour valves, but the maximum temperature remains marginal in the Superheater, requiring major redesign to conform to DWPF requirements. The drains have been tested. As a result, additional heaters have been added to the Superheater drain. The pour valve inlet has been shortened to enhance glass flow and achieve better pour rates. Primary Tank drain, as designed, is acceptable for flow control; however, heating in this area is inadequate and has required auxiliary gas heating to operate. The Primary Tank spout has operated satisfactory. However, the spout had a restrictive opening which slows glass flow and causes excessive glass head build up in the Primary Tank. 
WSRC-TR-99-00305, Rev. 0

August 30, 1999

Main Pot Heat Up 6/21/99

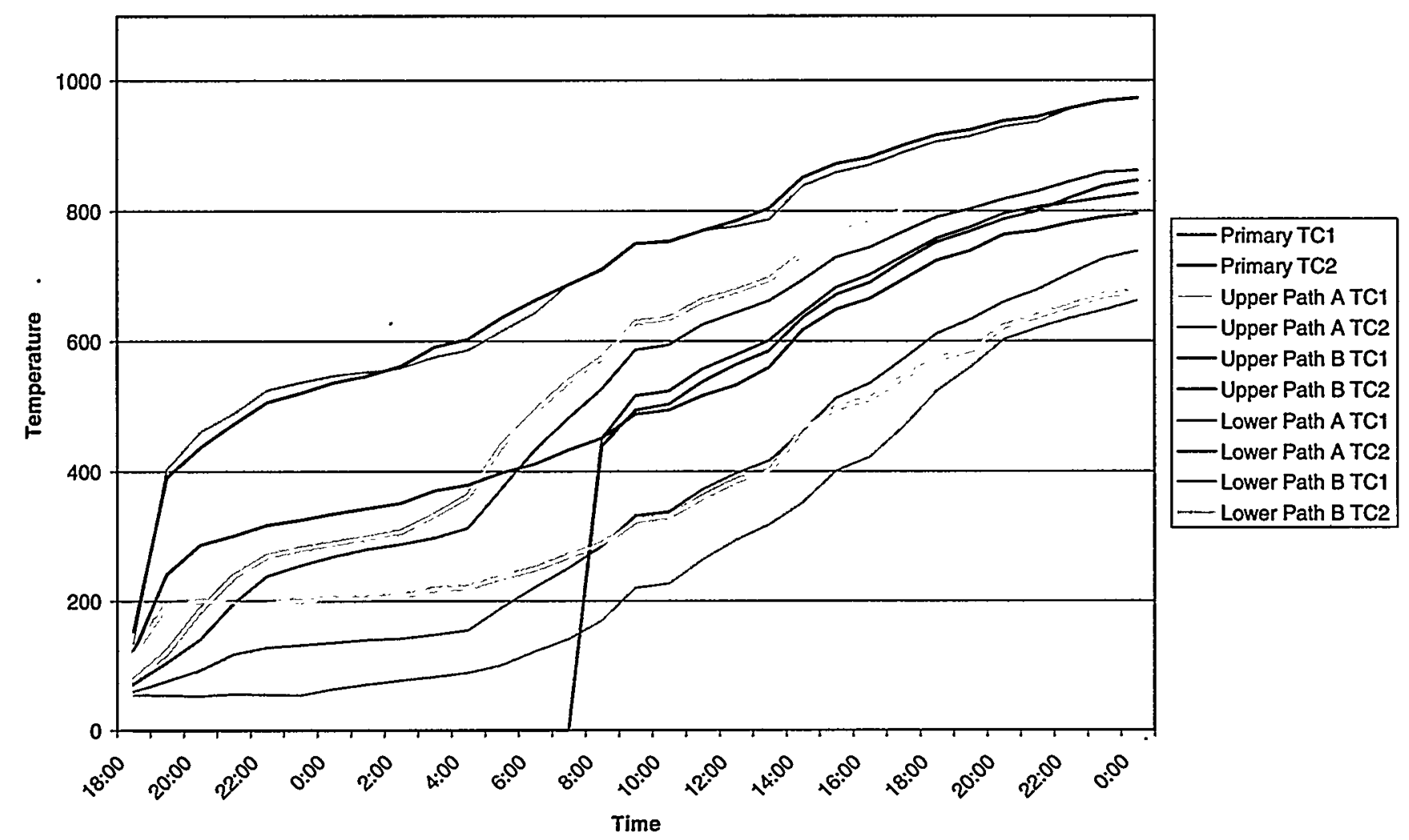




\section{Main Pot 6/21/99}

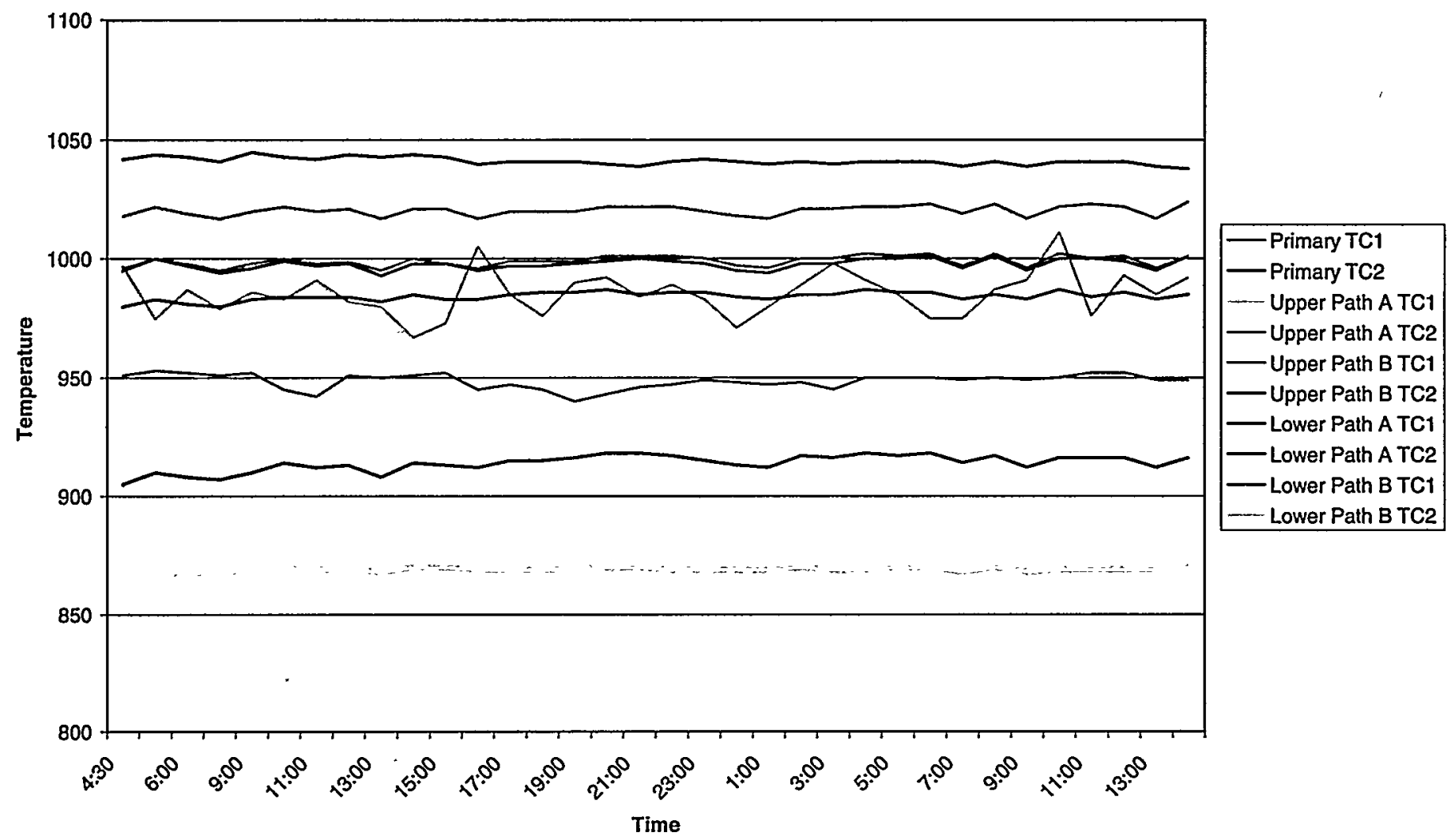

Melter Primary Tank temperatures at steady state without joule heat. The primary thermocouples are inside of the Tank. TC1 thermocouples are adjacent to the tank. TC2 thermocouples are adjacent to resistance heaters. The heaters are sufficient to heat the glass to start joule heating, but will not maintain the glass at the operating temperature of $1050^{\circ} \mathrm{C}$. 


\section{SuperHeater Checkout 5/17/99}

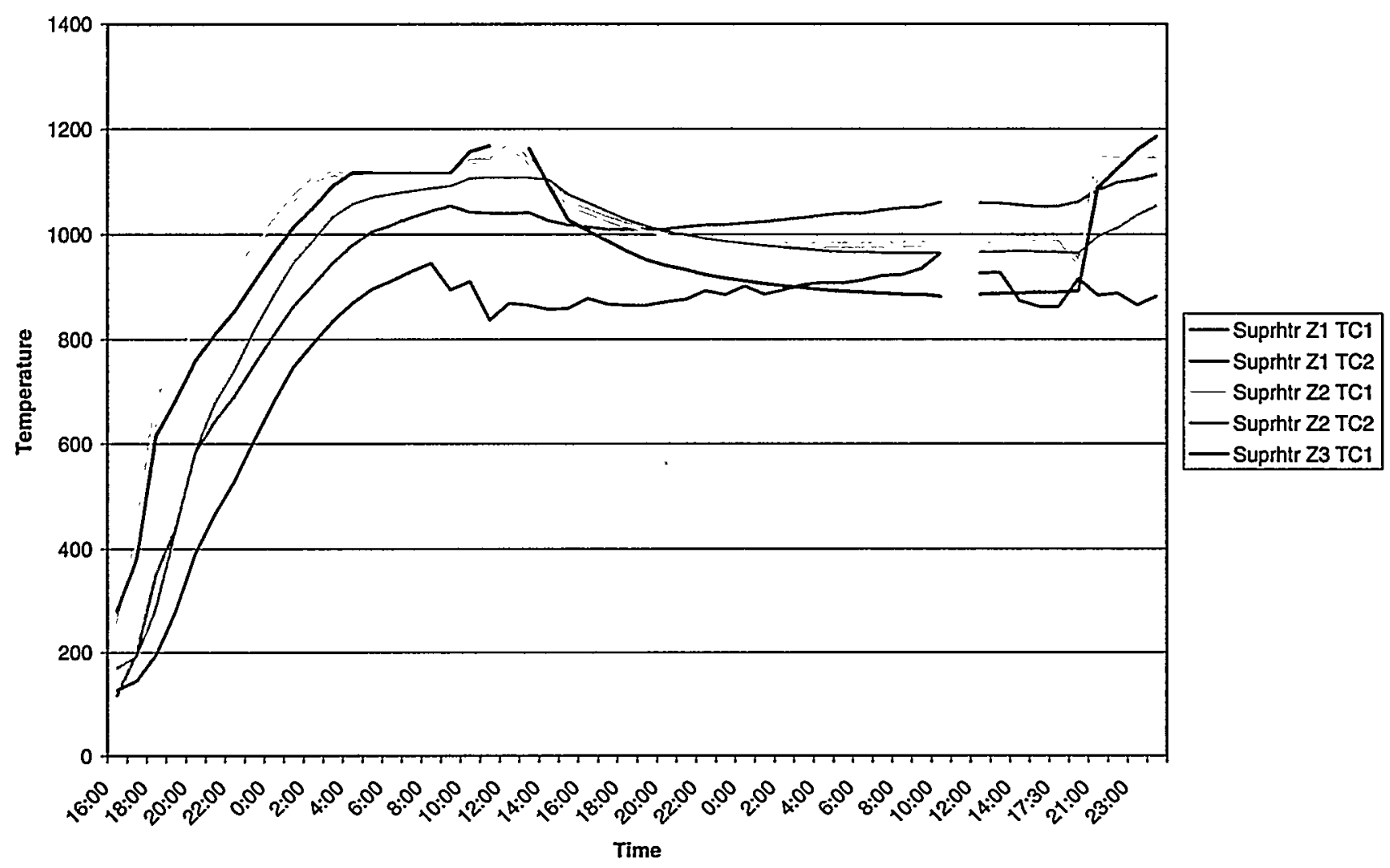

In the Superheater TC1 thermocouples are adjacent to heaters and TC2 thermocouples are adjacent to the tank. The heaters are not sufficient to uniformly to heat the glass to $1150^{\circ} \mathrm{C}$. 
WSRC-TR-99-00305, Rev. 0

August 30, 1999

Superheater 6/21/99

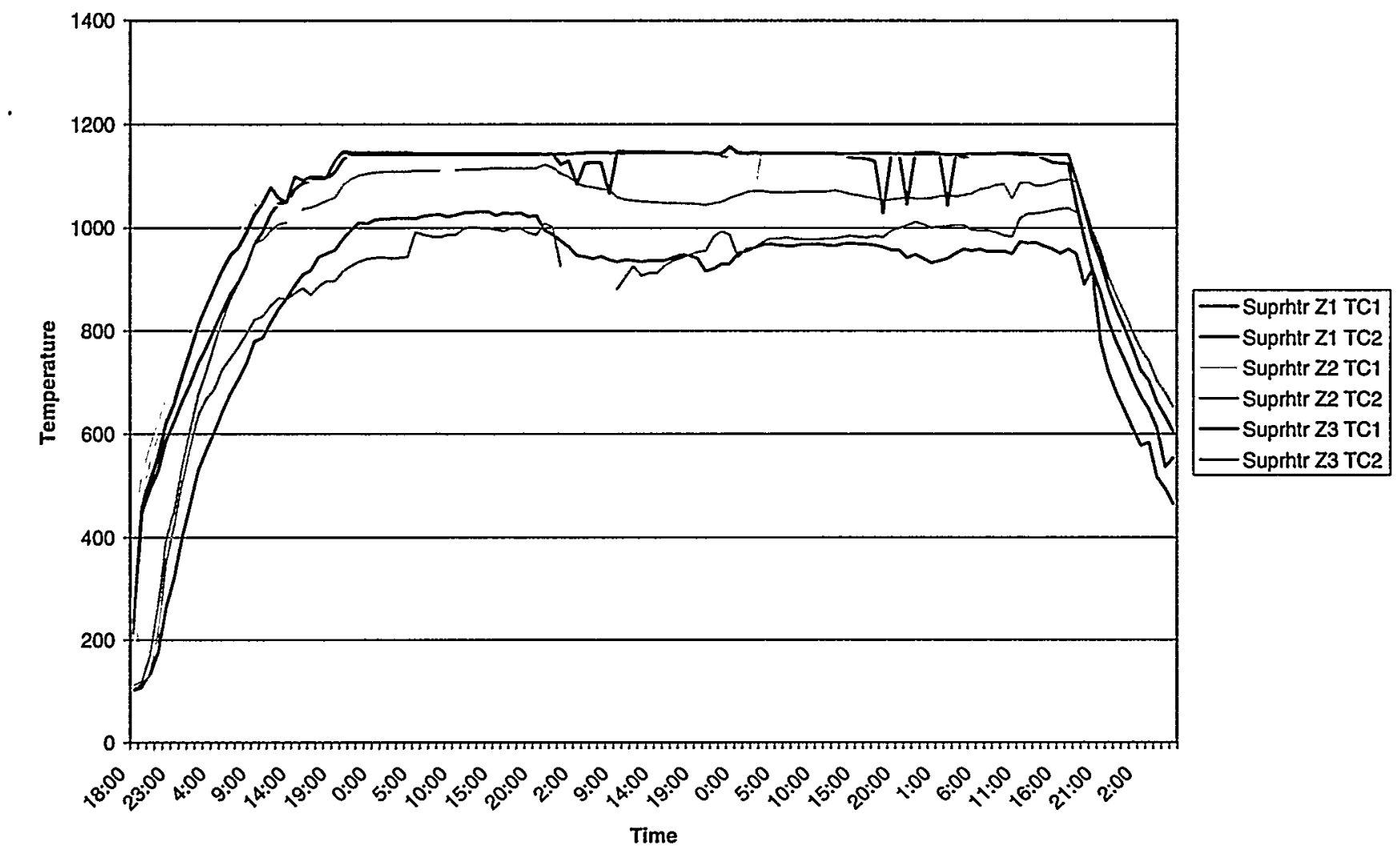

Superheater temperatures after installation of auxiliary heaters. Glass temperatures are more uniform but are below the desired $1150^{\circ} \mathrm{C}$. 
Pour Spout Temperatures 6/22/99

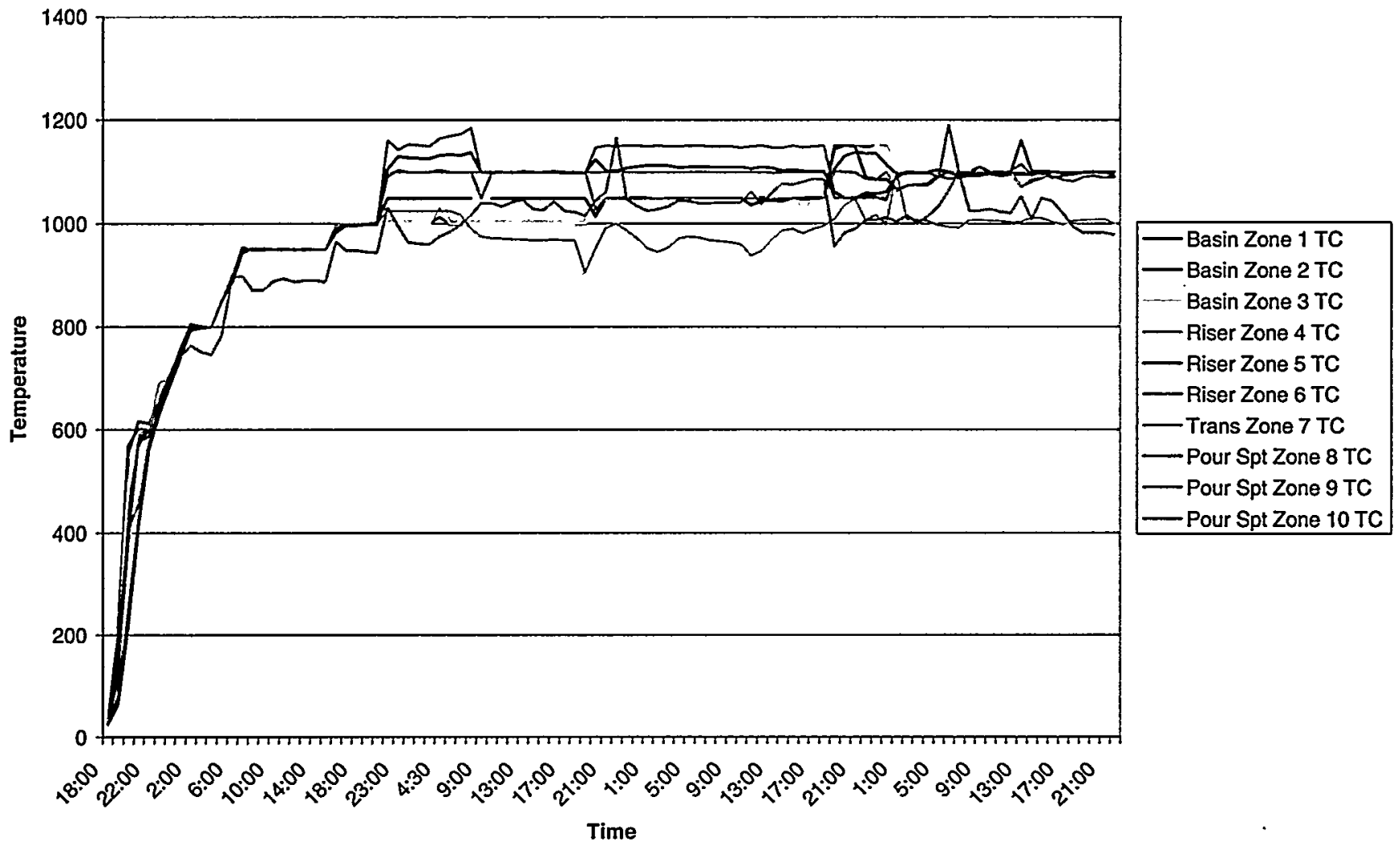

Temperatures of the DWPF test Riser and Pour spout set mimic the actual melter. 
WSRC-TR-99-00305, Rev. 0

. August 30, 1999

Pour Spout 5/17/99

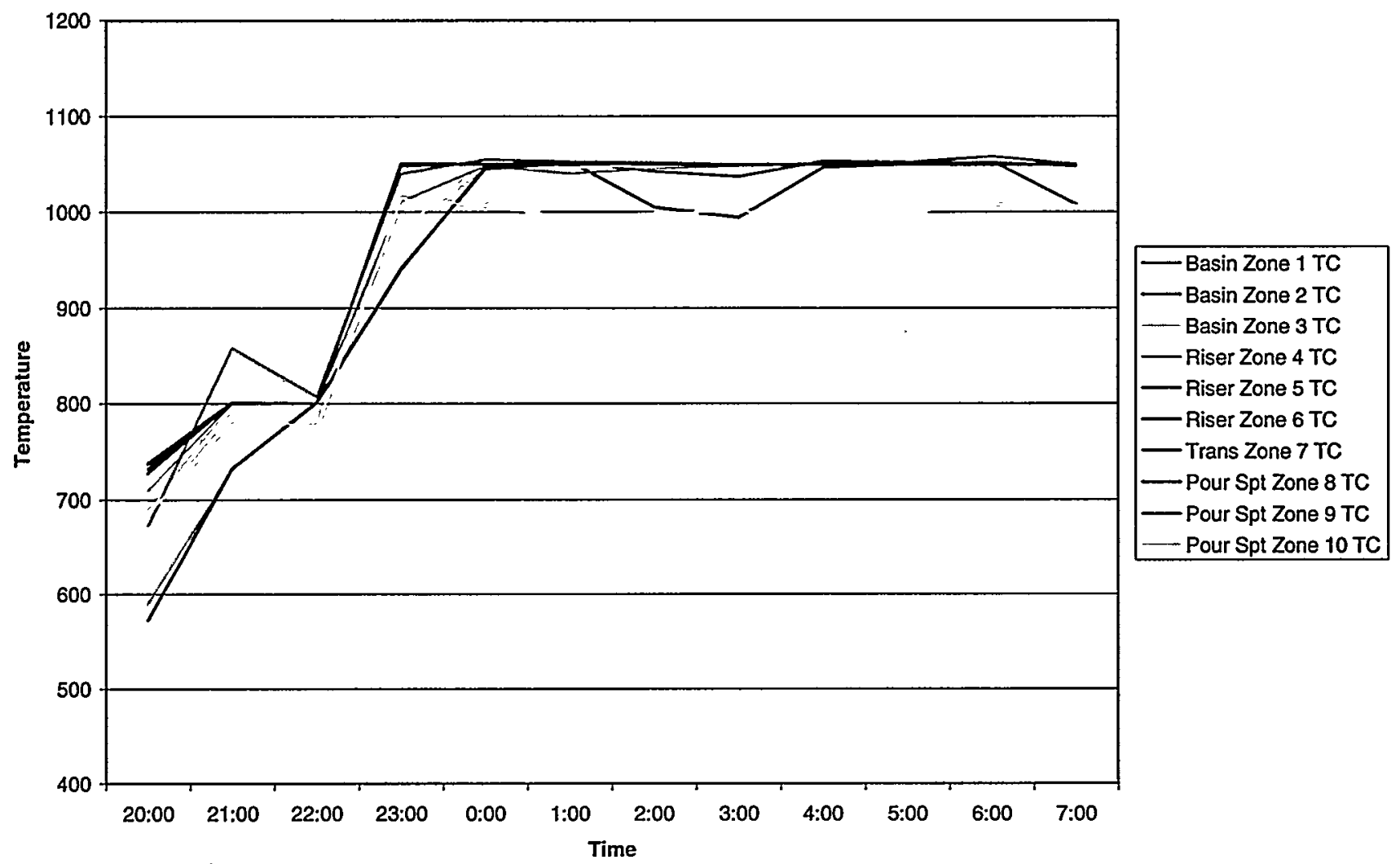

Temperatures in the DWPF test Riser and Pour Spout, $1050^{\circ} \mathrm{C}$ setpoint. The glass enters the holding basin at Zone 1 and enters the Riser at Zone 4, transitions to the Down Spout at Zone 7. The bottom of the spout is cooler because of radiative heat lose from the bottom. 


\section{Drain Side 6/21/99}

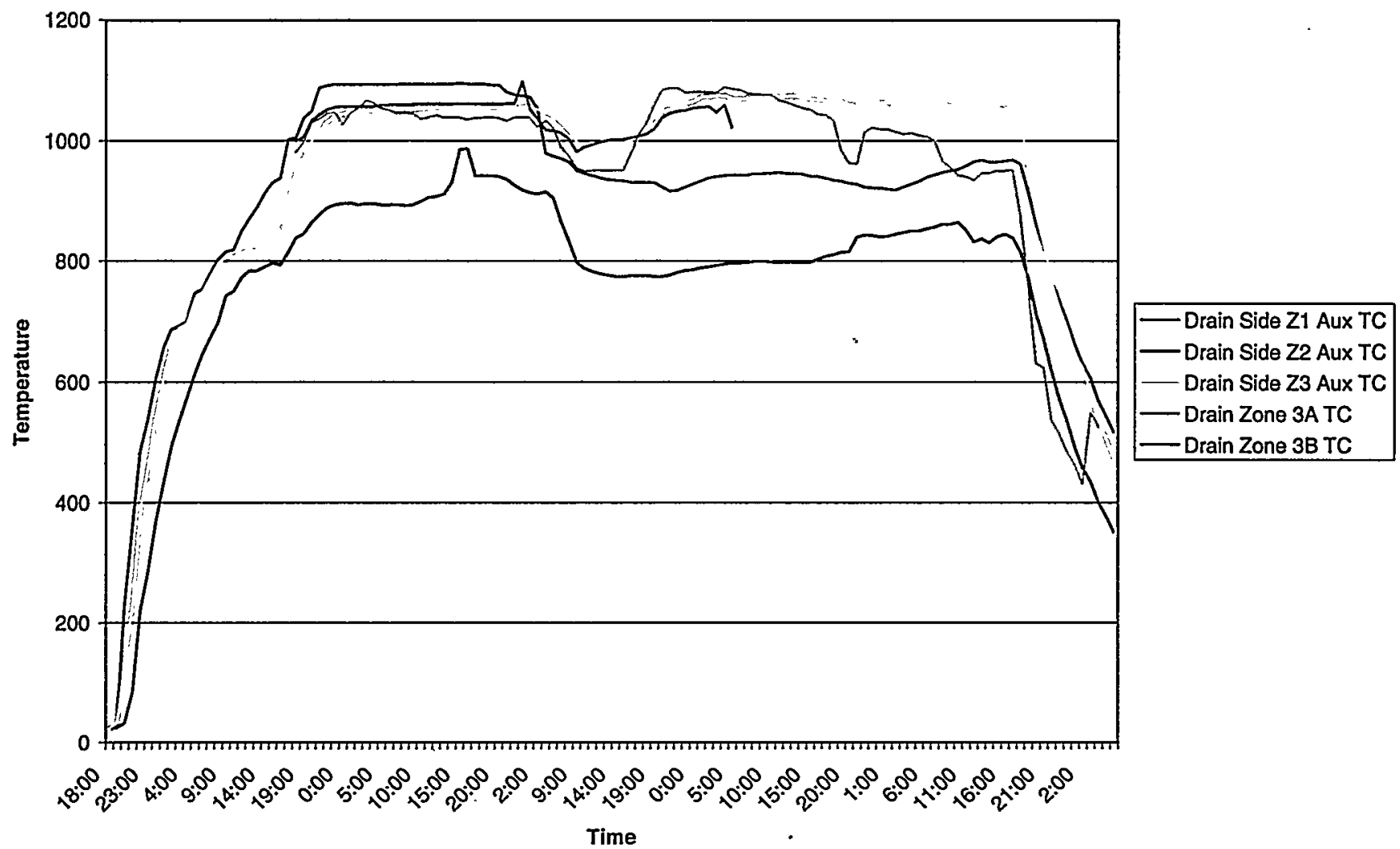

Temperatures of the auxiliary heaters installed to improve glass heating in the Superheater. (5 auxiliary heaters). 
Drain Side 5/17/99

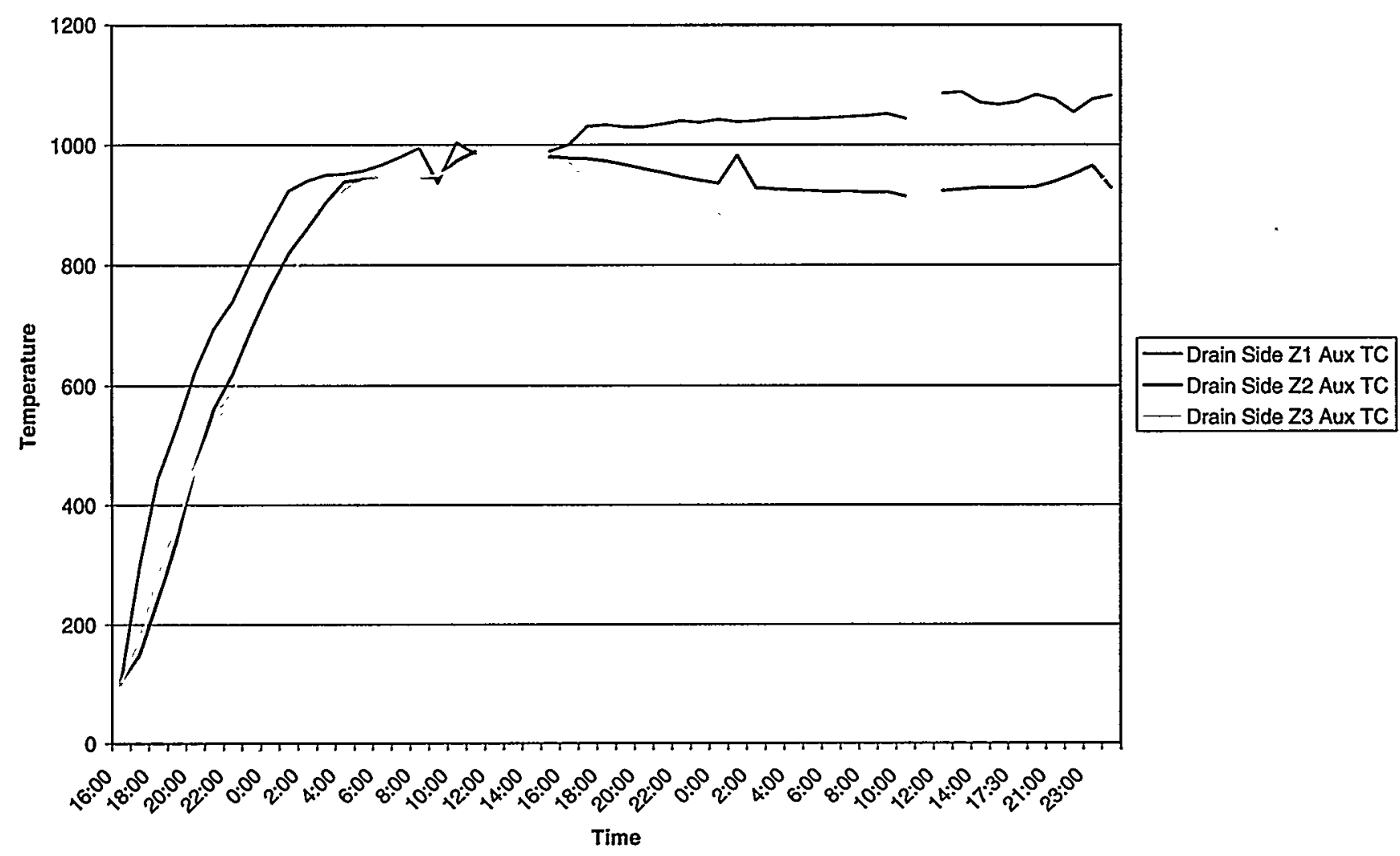

Temperatures of the auxiliary heaters installed to improve glass heating in the Superheater. ( 3 auxiliary heaters). 
- Comparison of melt rates with conventional melter (melt rate enhancement)

Melt rates in the tank with DWPF surrogate glass were above 800 pounds per hour with dry feed. This is approximately equivalent to 400 pound per hour with slurry feeding. This is well above the minimum design requirement of 228 pounds per hour. These tests were conducted at $2 / 3$ of the rated capacity of the power supply, indicating that still higher slurry feeding rates may be possible.

\section{- Potential improvement list}

Major operability issues were addressed by modification of the cooling water system, joule power system, and Superheater power system. Improvement is required in the Primary Tank spout and drain, and level detection and control. Major redesign and testing of the Superheater would be required for radioactive service.

- Remoteability evaluation

The compact modular design of the stirred melter appears suitable for high capacity remote radioactive service. Increased operating time is necessary to determine estimated life. A smaller Superheater with increased heater capacity and remotely replaceable thermocouples, and spout and drain heaters would be required. In the Primary Tank the Inconel $690^{\mathrm{TM}}$ should be separated from the resistance heaters, insulation and cooling water jacket by a secondary containment tank. The cooling water jacket around the Primary Tank and the Superheater do not appear to be required, and would simplify installation and operation.

\section{Pour Spout Tests}

Thermal-Hydraulic Parameter Tests with Nominal Knife-edge Geometry

- Effect of flow: 50 to $>250 \mathrm{lbs} / \mathrm{hr}$ (400 lbs/hr desired); nominal $228 \mathrm{lbs} / \mathrm{hr}$

Tests have been conducted at $20-400 \mathrm{lbs} / \mathrm{hr}$

While the Superheater pour and drain spouts have nearly identical designs, flow rates through the pour spout have been lower than desired. Auxiliary heaters have been added to this area of the Superheater. During testing it was noticed that the pour stream became erratic when the glass level was less than two inches high above the entrance to either of these flow control devices. Consequently, the stand pipe at the entrance to the pour spout was shortened to increase the hydraulic head at the entrance and permit a more fully developed flow.

- Effect of glass temperature: 950 to $1100^{\circ} \mathrm{C}$

Testing has been conducted with the maximum temperatures available with conservative settings of Superheater power assemblies. Apparent in-tank glass temperature of $1030^{\circ} \mathrm{C}$ was achieved with heater assemblies at $1175^{\circ} \mathrm{C}$. The simulated DWPF riser and pour spout mimics DWPF spout temperature gradients and follows the set points of the zone heaters. In the lower section of the spout high radiative heat loss causes glass to adhere to the spout. This is similar to the DWPF Melter. 
- Effect of glass/spout temperature difference

In addition to operations with glass and spout at nominal DWPF conditions, the system was tested with $1050^{\circ} \mathrm{C}$ spout and $1150^{\circ} \mathrm{C}$ glass, as well as $1150^{\circ} \mathrm{C}$ spout and $1050^{\circ} \mathrm{C}$ glass. Flow was generally more predictable with higher spout temperatures.

- Effect of pour spout temperature gradient

Temperature gradient measurements have been made in the spout with and without an insert. They have been measured with a thermocouple, similar to those used to characterize the DWPF spout, and by infrared thermography.

- Effect of transients

Several series of tests have been performed. Known masses of glass have been instantaneously added to the glass hold tank. The additions result in a step function increase of head pressure in the hold tank which is identical in effect to a decaying step function increase in pour pressure in the DWPF. In particular, the increase in pour rate has been seen to cause wicking, erratic behavior of the pour stream, and changes in the general flow pattern of the spout. The resulting transients were videotaped in the spout and are shown in Figures 3-12. 
Figure 3. Glass Stream Behavior Inside an Insert During a 7.8 lbs Surge (09:58-5/19/99)

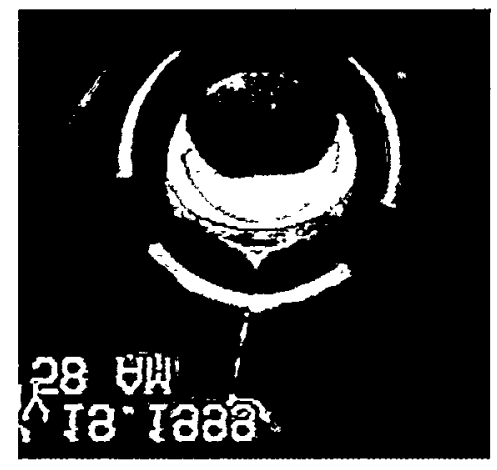

a

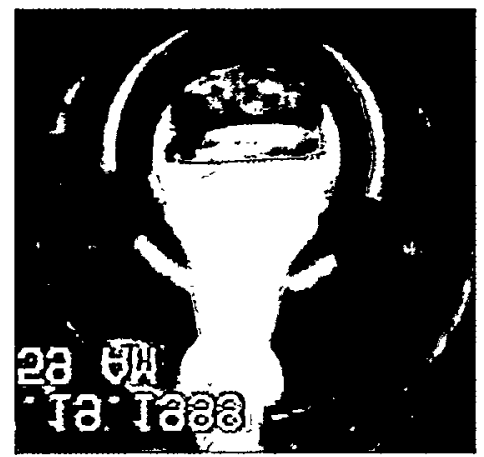

d

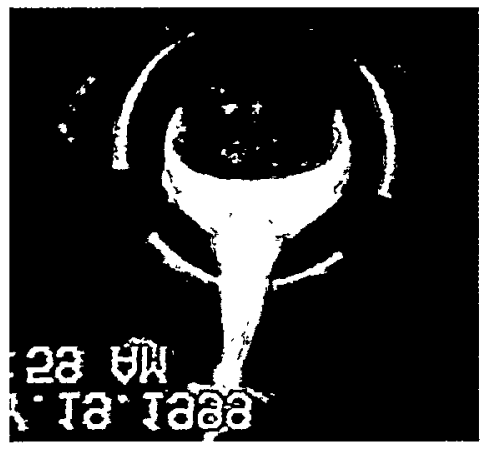

g

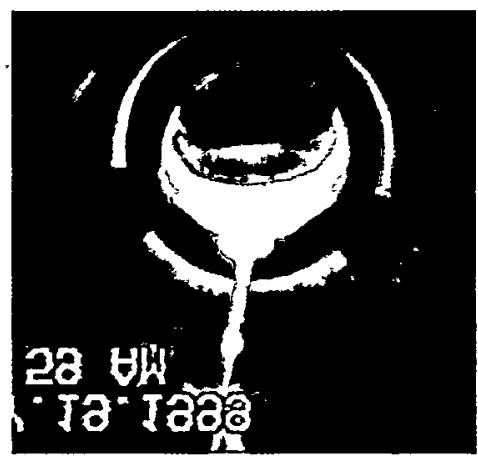

j

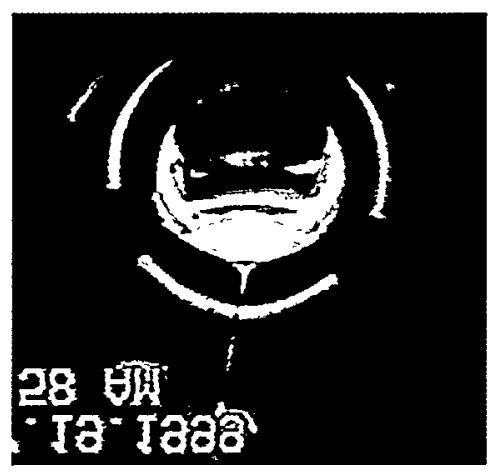

b

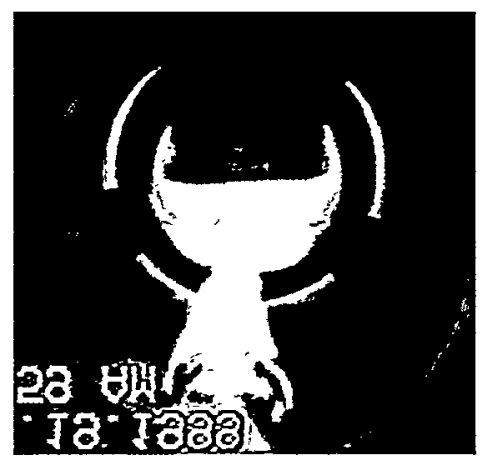

e

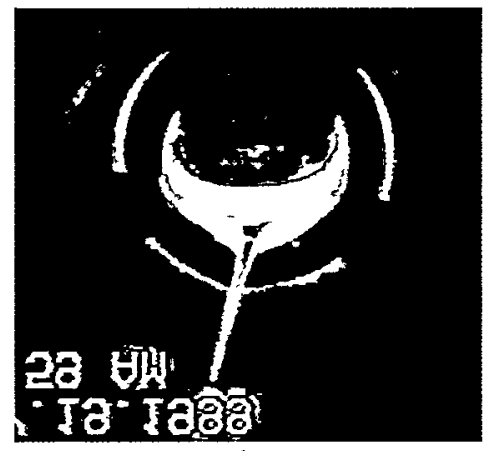

$\mathrm{h}$

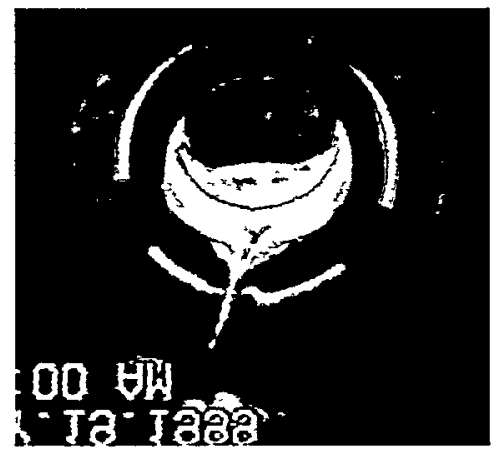

k

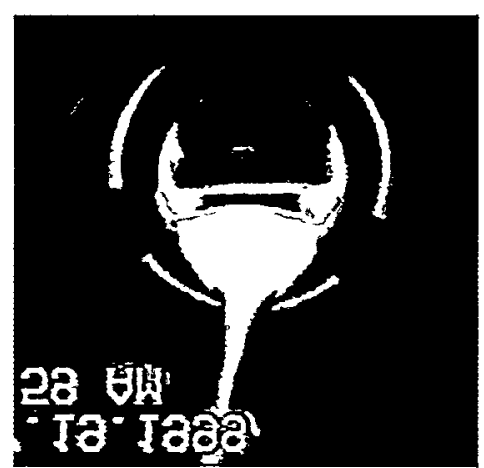

C

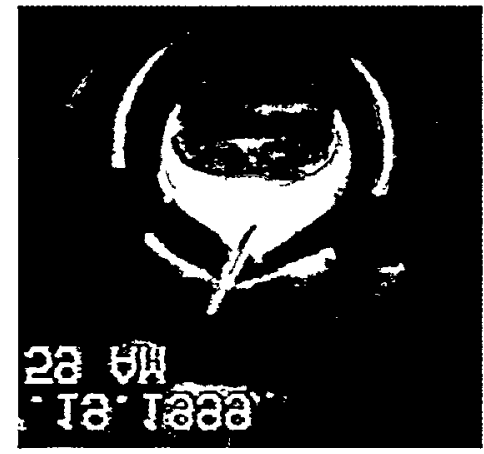

$f$

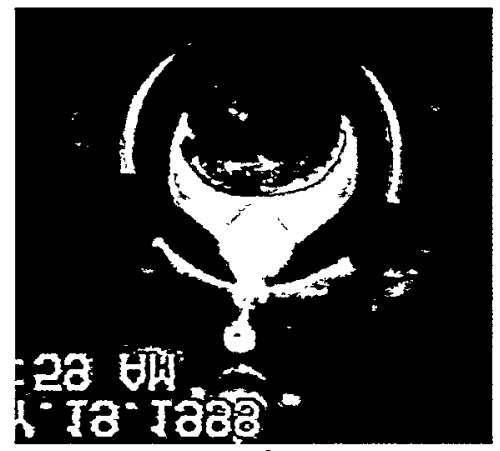

i

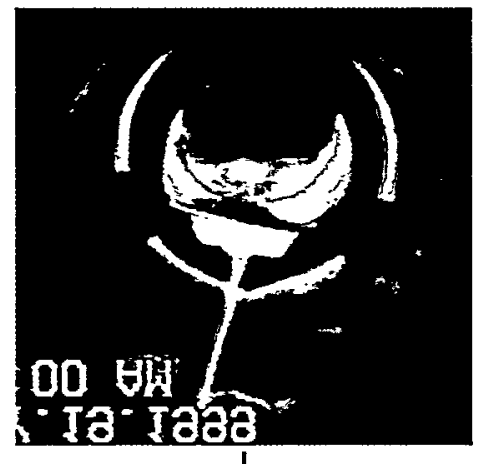


Figure 4. Glass Stream Behavior Inside an Insert

At $125 \mathrm{lbs} / \mathrm{hr}$ and $4 \mathrm{lbs}$ Surge (23:16-6/25/99)

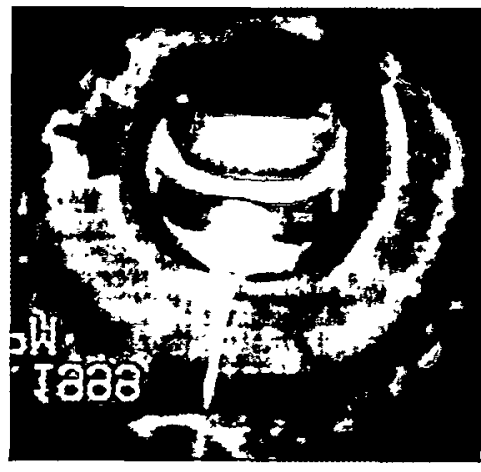

a

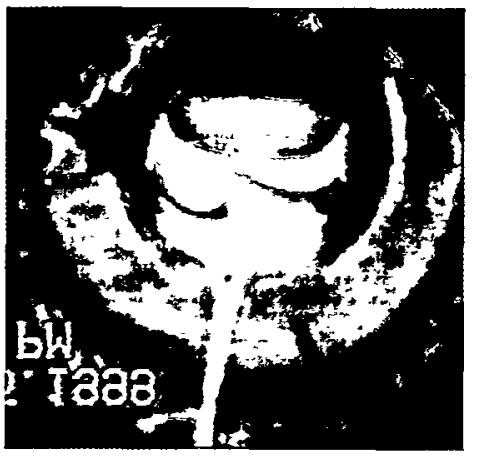

d

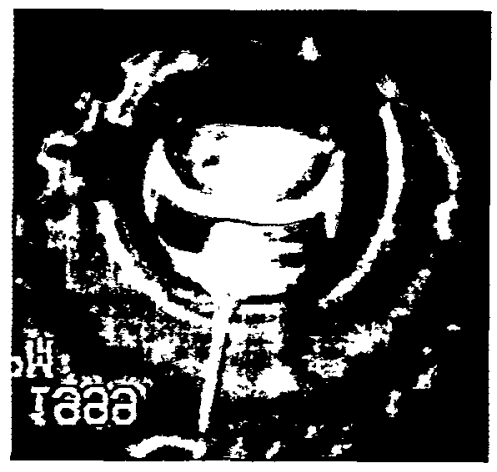

b

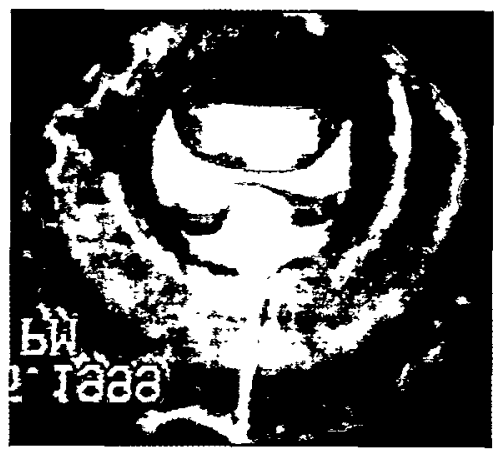

e

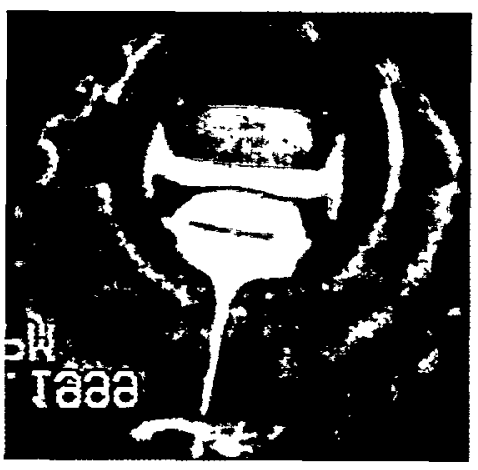

C

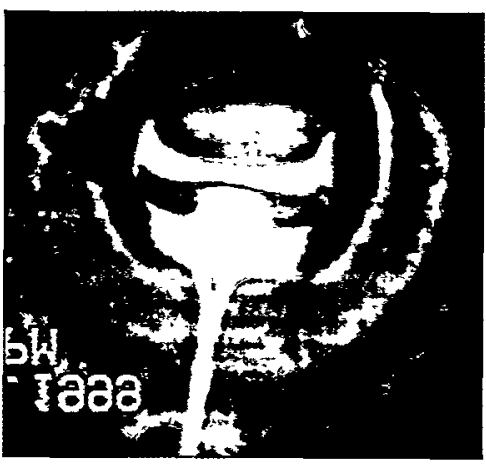

f

In this run, the steady state flow was $125 \mathrm{lbs} / \mathrm{hr}$. Figure $4 \mathrm{a}$ shows the position of the glass stream separation prior to the surge which is from the insert knife-edge. Figures $4 \mathrm{~b}$ and $4 \mathrm{c}$ show the progress of the surge front from a 4 pound glass chunk dropped into the reservoir at the pour spout and insert, respectively. The glass stream separating from the insert knife-edge grew in diameter (Figure 4d) moved slightly to the right and then moved back to center. There was no large movement of the glass stream evident from the side camera recording. 
Figure 5 Glass Stream Behavior Inside an Insert At $125 \mathrm{lbs} / \mathrm{hr}$ Flow and 8 lbs Surge (23:25-6/25/99)

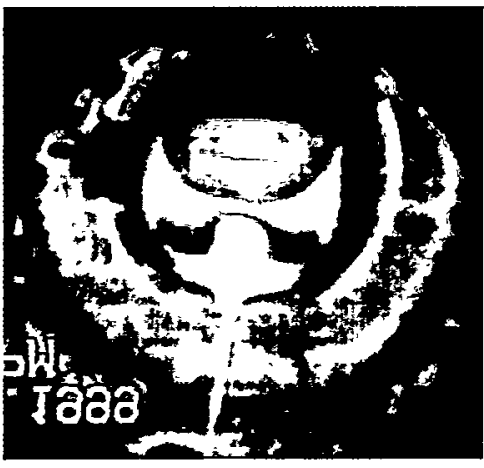

a

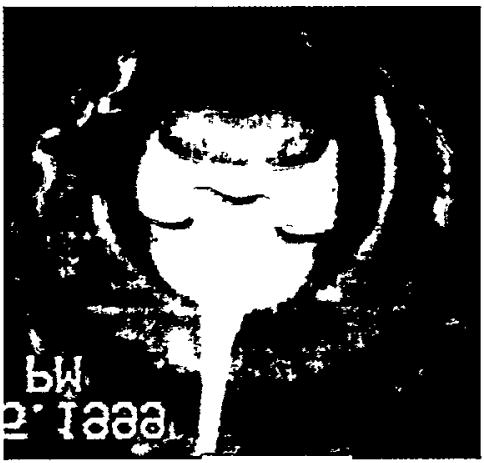

d

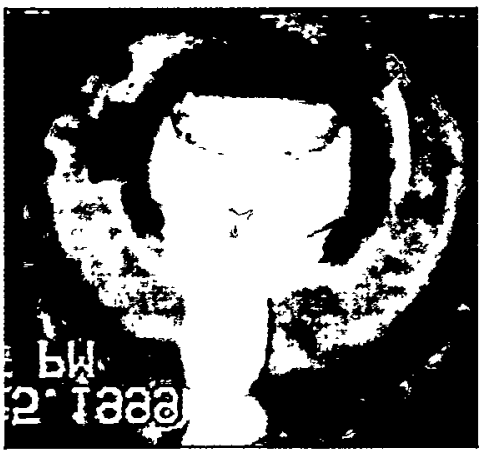

g

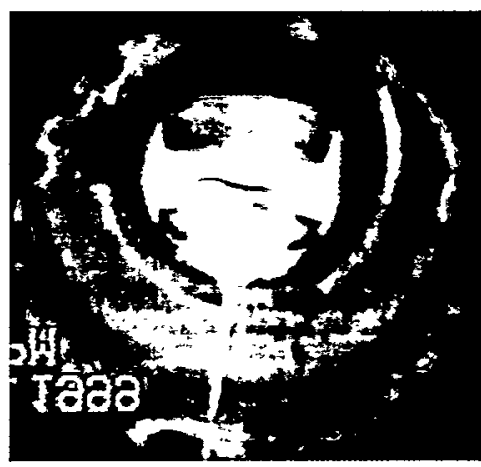

b

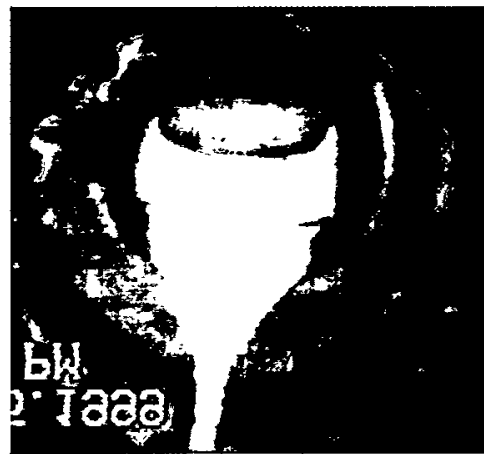

e

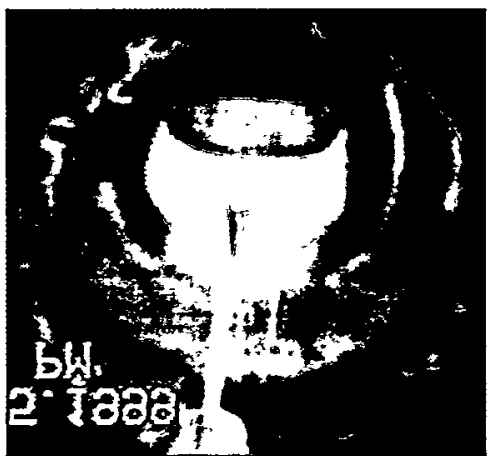

h

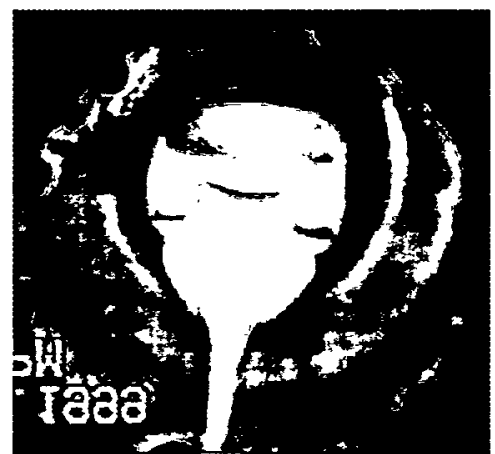

C
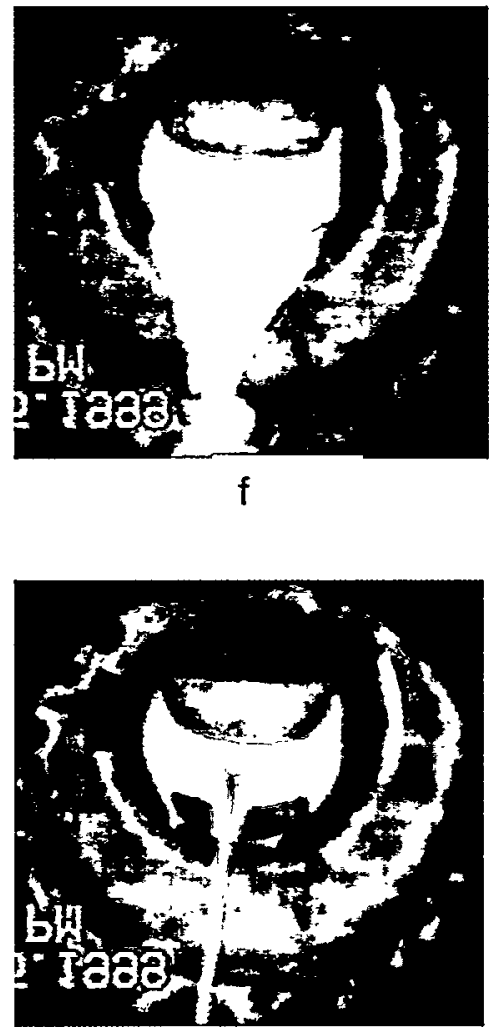

i

In this run, the steady state flow was $125 \mathrm{lbs} / \mathrm{hr}$. The glass stream was separating from the insert knife-edge centerline, as shown in Figure 5a. This figure also shows the surge front from a transient generated by dropping a 8 pound glass chunk into the reservoir. Figure $5 \mathrm{~b}$ shows the surge front travelling down the insert. Figures 5c-5d show the increasing height of the fluid inside the insert. Figure 5e shows the large glass hump reaching the insert knife-edge and deflecting backwards. The deflected glass stream then hits the edge of the opening in the insulation, which is at least 4-inches in diameter. Figures $5 \mathrm{~g}-5 \mathrm{~h}$ shows termination of the large wick. Finally, Figure 5i shows the glass stream reaching a steady state and separating from the pour spout knife-edge centerline. 
Figure 6 Glass Stream Deflections During a $8 \mathrm{lbs}$ Surge at $125 \mathrm{lbs} / \mathrm{hr}$ Flow (23:25_6/25/99)
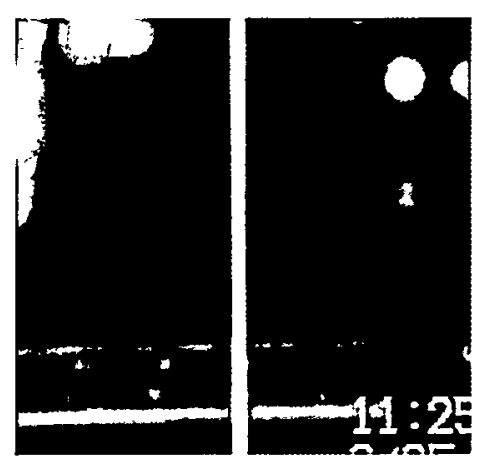

a

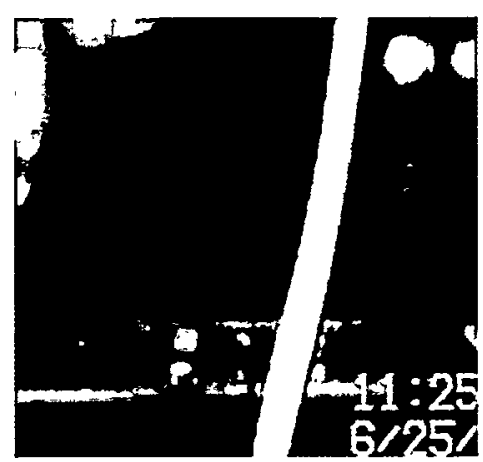

d

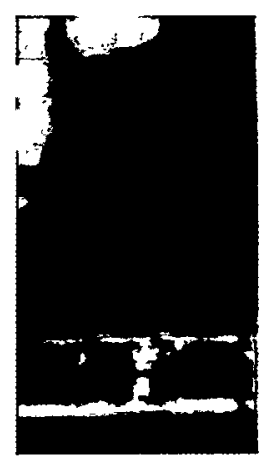

b

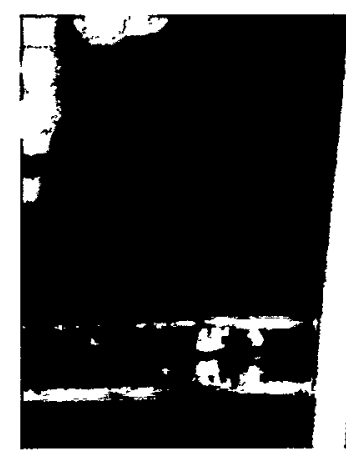

e
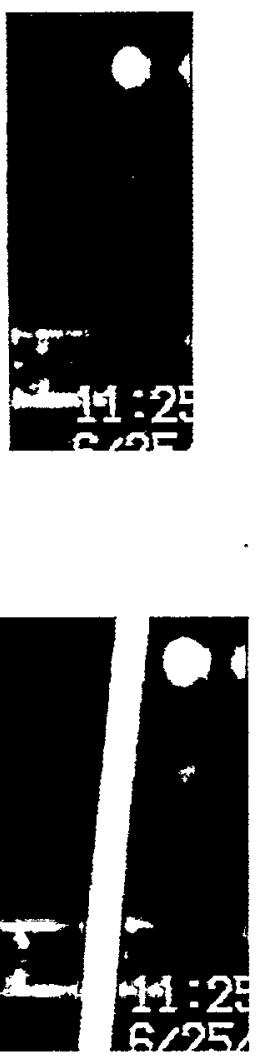

A.25:
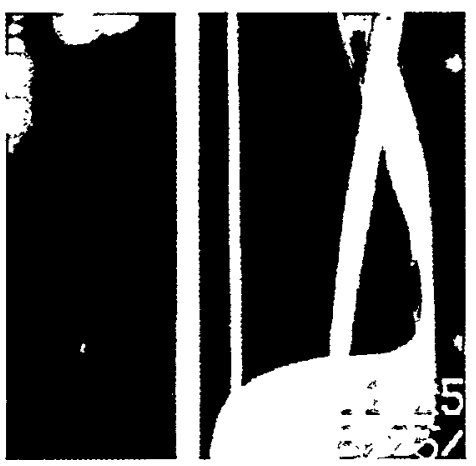

f c

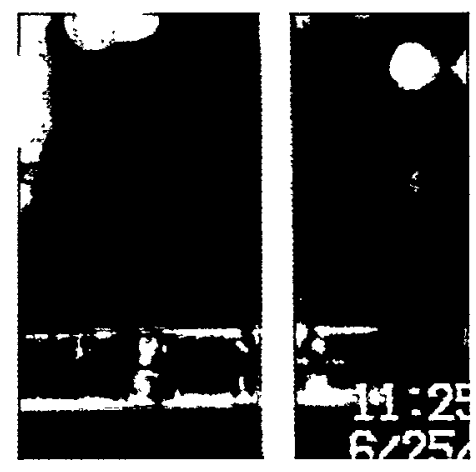

Figure 6 provides some video clips from the side camera. Figure $6 a$ shows the position of the stream before the surge. Figure $6 \mathrm{~b}-6 \mathrm{e}$ show the increase in stream width and brightness during the surge and its movement backwards towards the riser (to the right in the figure). Figure $6 \mathrm{f}$ shows the multiple stream resulting from the large wick hitting the insulation. 
Figure 7. Glass Stream Behavior Inside an Insert

At $155 \mathrm{lbs} / \mathrm{hr}$ Flow and $3.9 \mathrm{lbs}$ Surge (21:54-6/25/99)

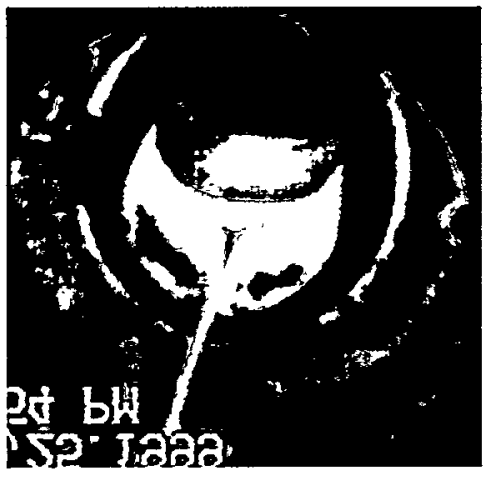

a

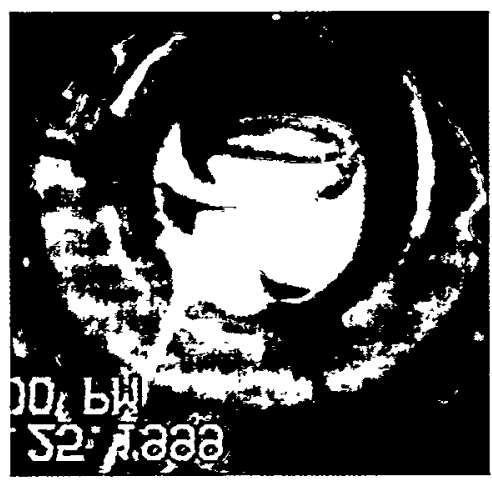

d

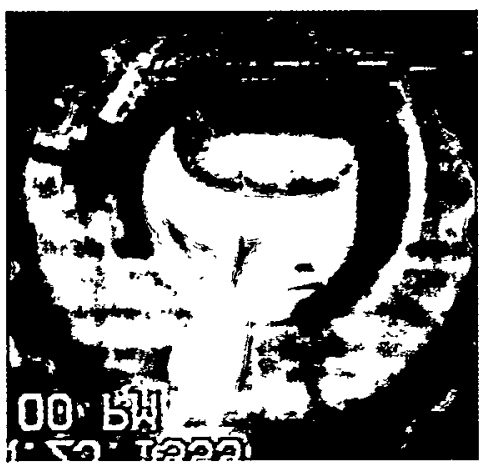

g

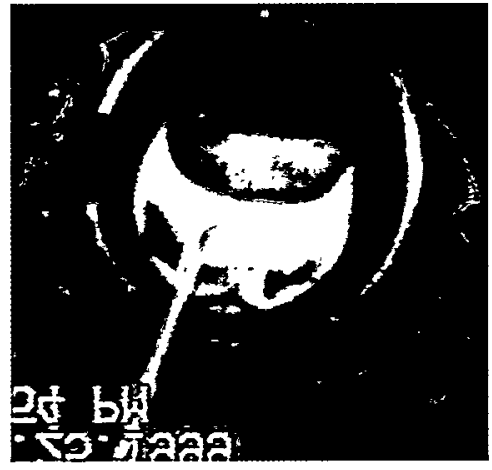

b

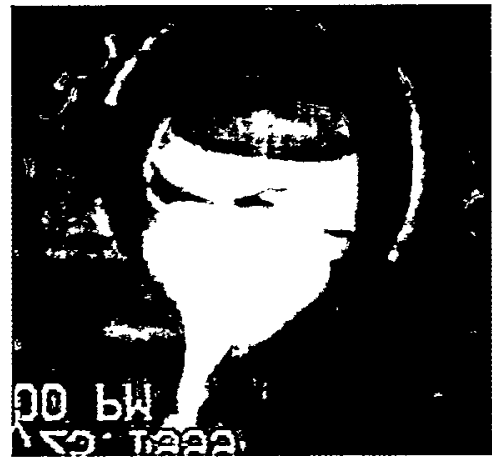

e

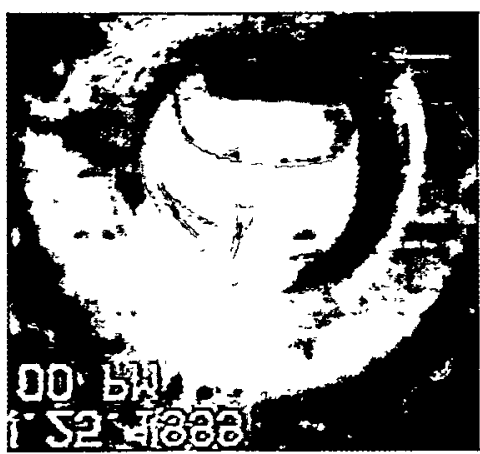

h

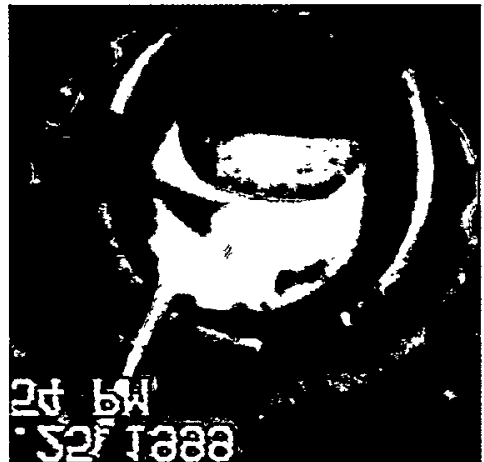

C

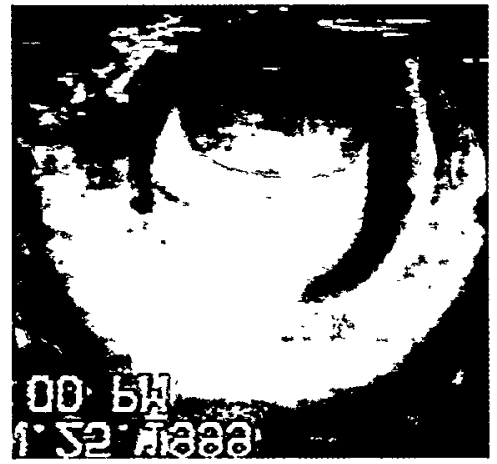

f

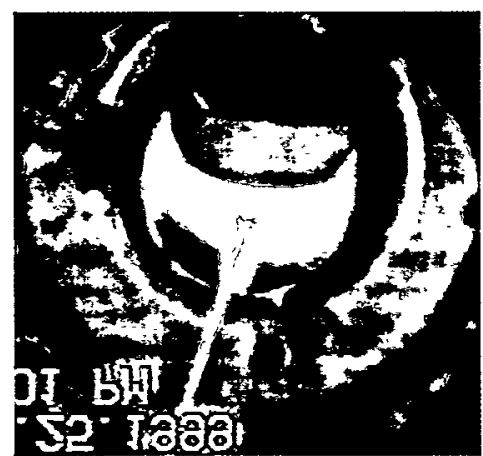

i

In Figure 7, the steady state flow was $155 \mathrm{lbs} / \mathrm{hr}$ and the glass stream was separating from pour spout knifeedge. Because of the high flow and the small 3.9 pound glass chunk dropped into the pour spout reservoir, the surge front is not evident. However, the increase in flow causes the separating stream to swing to the left, probably because the underside of the separating stream touches the insert wall and by capillary action pulls the stream to the left. The glass then collects on the insert wall and interrupts the flow past the insert. The collecting glass then reaches the insert knife-edge and drops off the insert knife-edge. A steady state flow then develops where a flat meniscus develops inside the insert. The glass stream then separated from the insert knife-edge at 30 degrees to the left of the spout centerline. 
Figure 8, Glass Stream Deflection Recorded by Side Camera

During a $3.9 \mathrm{lbs}$ Surge and $155 \mathrm{lbs} / \mathrm{hr}$ Flow (21:54-6/25/99)

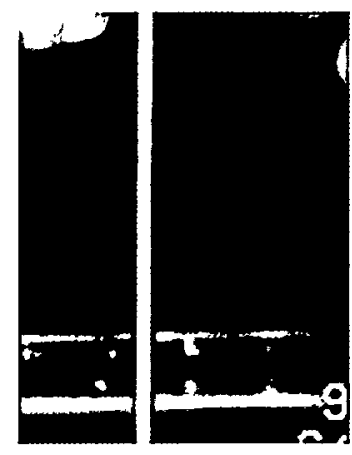

a

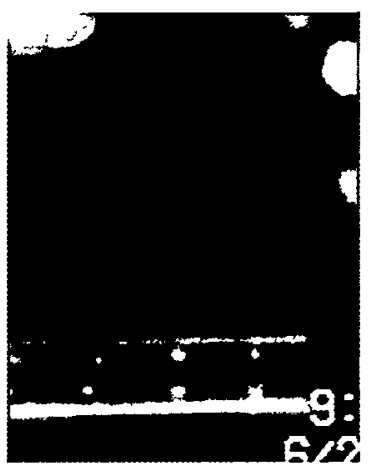

b

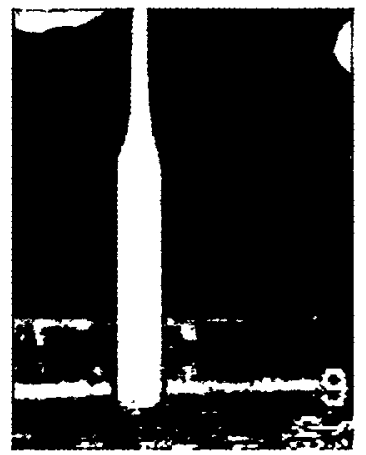

C
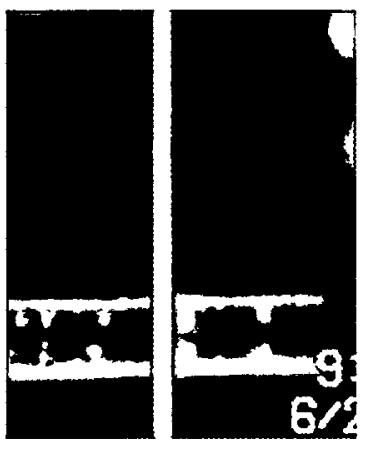

d

Video clips from the side camera are shown in Figures 8. Figure 8a shows the initial position of the glass stream when the stream was separating from the insert knife-edge centerline. Figure $8 \mathrm{~b}$ shows that the glass stream then disappears when it collected inside the insert. Figure $8 \mathrm{c}$ shows the front end of the glass stream separating from the insert knife-edge and Figure $8 \mathrm{~d}$ shows the final position of the glass stream. These images show that there was no large wicks observed during this test. 
Figure 9. Glass Stream Behavior Inside an Insert At $155 \mathrm{lbs} / \mathrm{hr}$ Flow and $8 \mathrm{lbs}$ Surge (22;00-6/25/99)

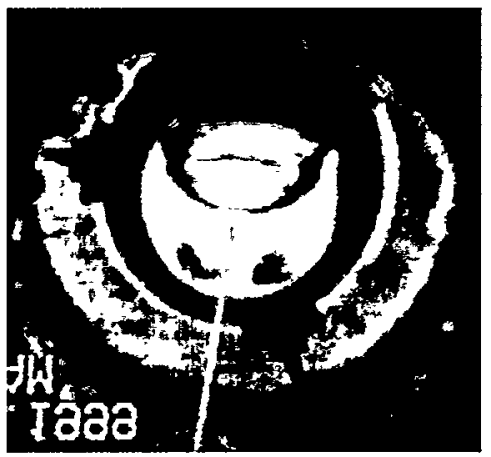

a

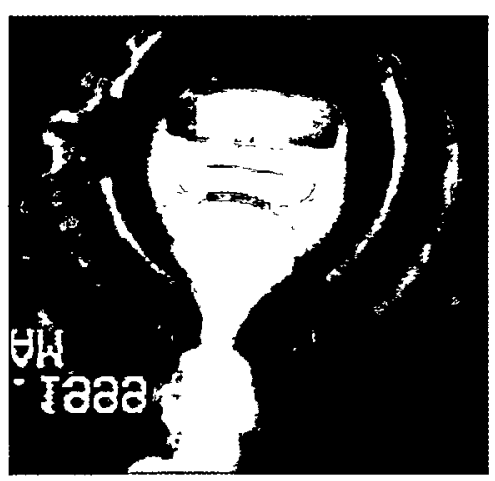

d

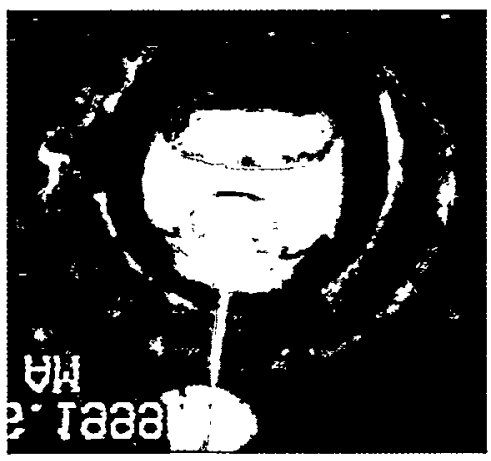

g

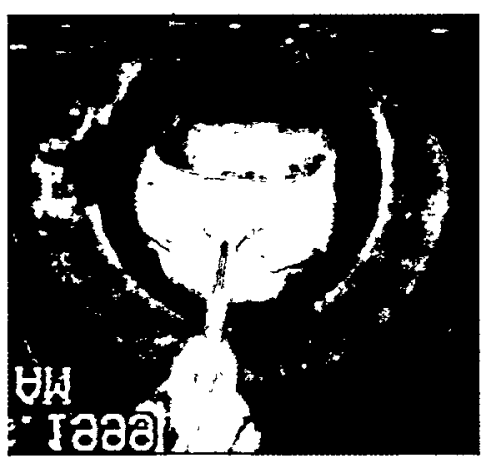

j

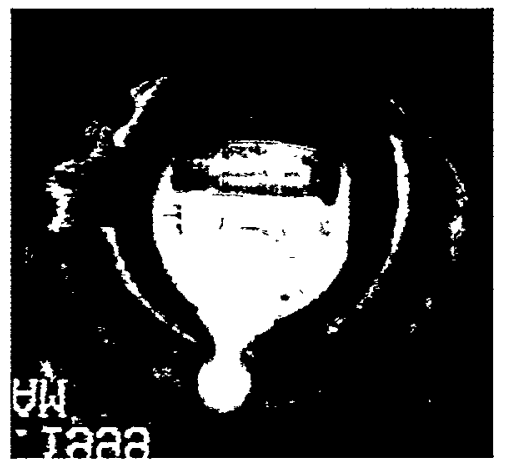

b

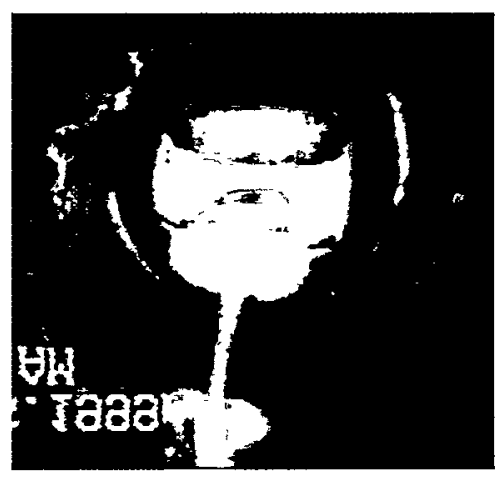

e

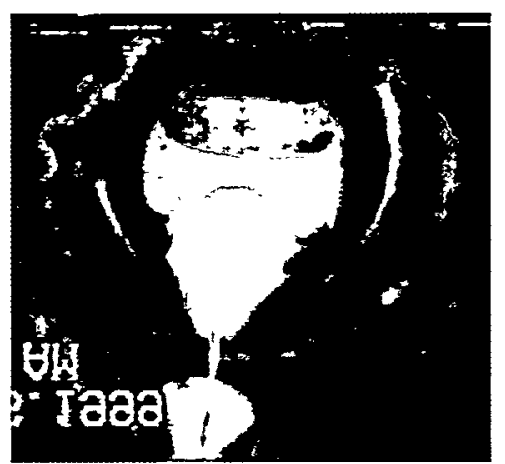

$\mathrm{h}$

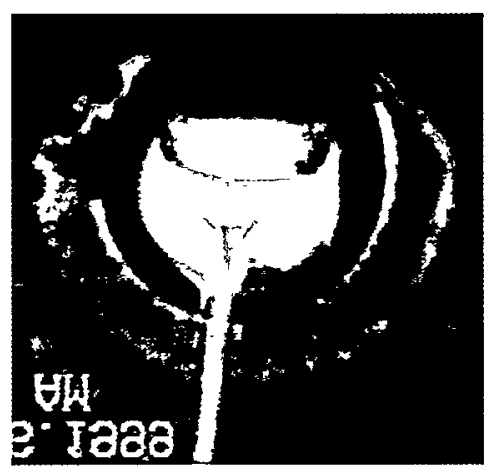

$\mathrm{k}$
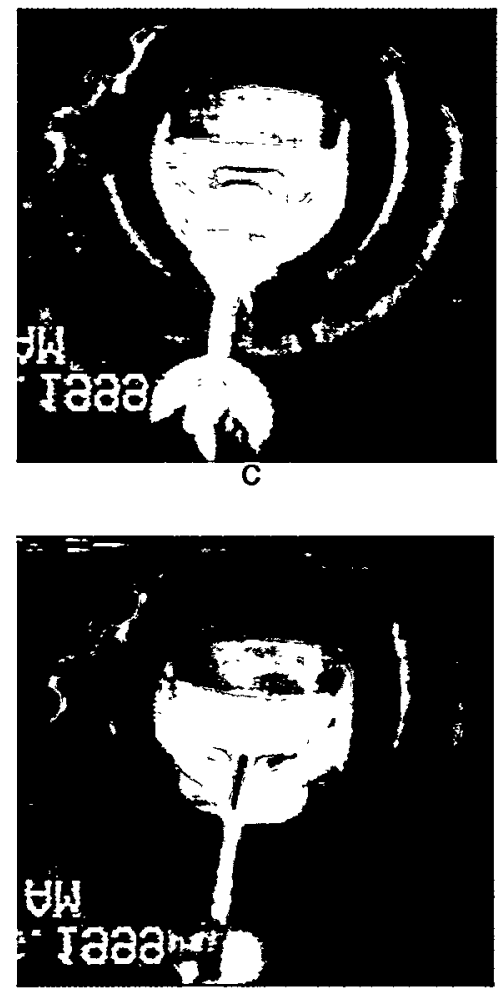

f

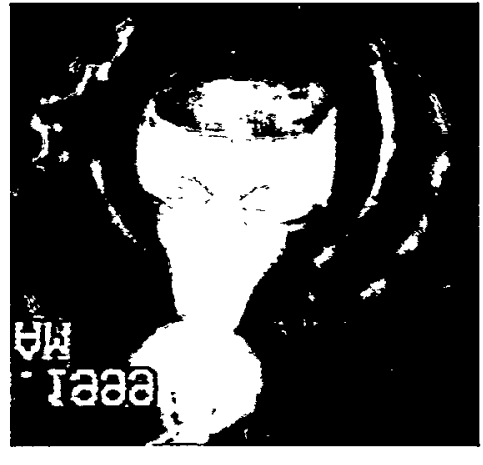

i

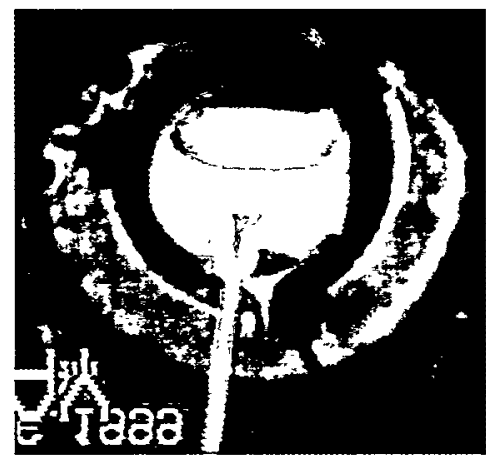

1 
In Figure 9a, the steady state flow rate was $155 \mathrm{lbs} / \mathrm{hr}$ and the glass stream was separating from the insert knife-edge at about 30 degrees to the left of the centerline looking towards the riser. This figure also shows the 8 pound surge front approaching the spout knife-edge. The flow built up inside the insert and there were several large wicks or wavering of the stream (Figures $9 b-c)$. When the level in the pour spout had decreased (Figure 9d) the stream separated from the pour spout knife-edge centerline. There was a residual stream behind the main stream draining from the insert ( Figure 9e) and drips (Figure 9f). In Figure 9g, the flow surge was decreasing and the stream was steady. Then the separating flow swung to the right (Figure $9 \mathrm{~h}$ ) and contacted the insert wall, interrupting flow (Figure 9i). In Figure 9j the flow again built up inside the insert and separated from the insert knife-edge, causing a large wick. In Figure $9 \mathrm{k}$ the stream was again steady, separating from the insert knife-edge at about 30 degrees to the right of the centerline. Then the stream moved to the center, (Figure 9l)

Figure 10. Glass Stream Deflection as Recorded by Side Camera

During a 8 lbs Surge at 155 Lbs/hr Flow (2200_6/25/99)

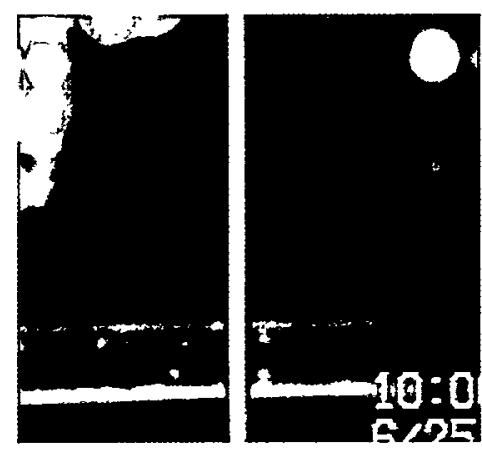

a
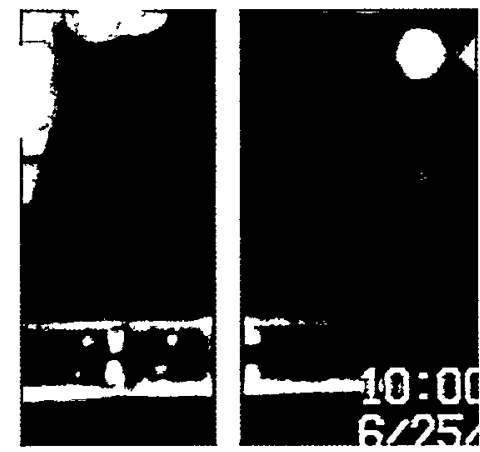

d

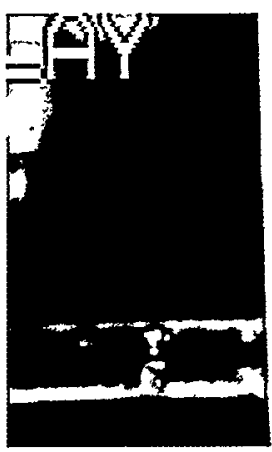

$\mathrm{b}$
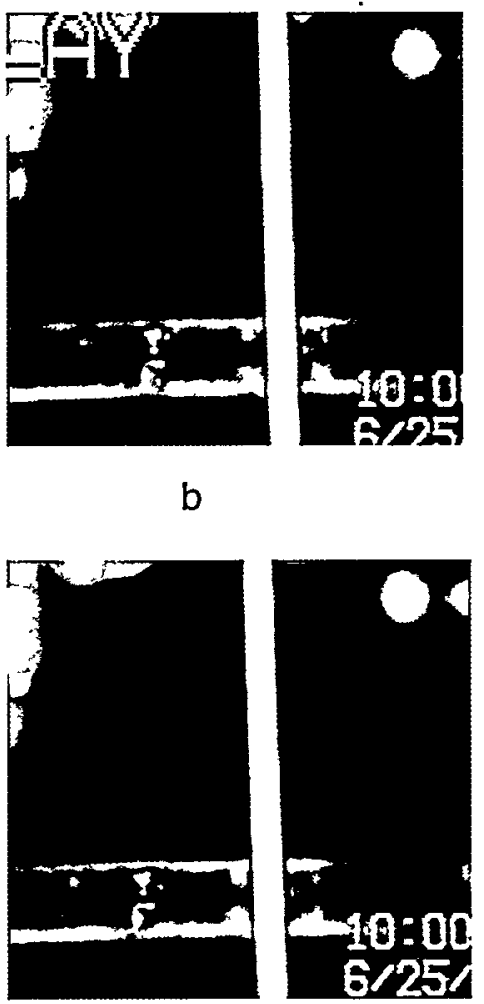
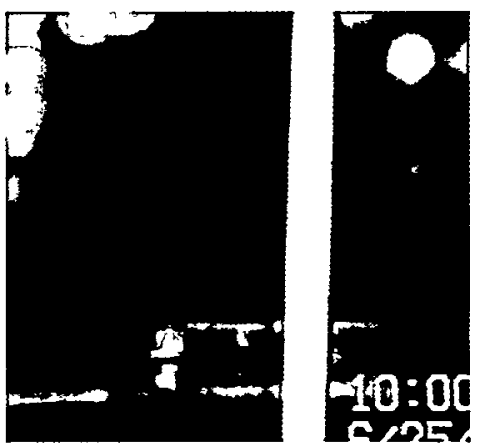

C

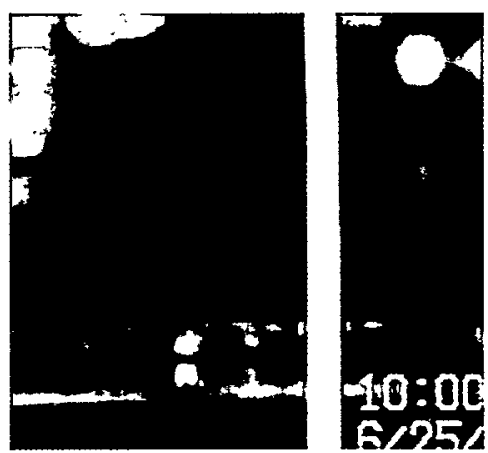

f

Some clips from video recordings with the side camera are shown in Figures 10a-10f. Figure 10a shows the initial position of the stream while Figures $10 \mathrm{~b}-10 \mathrm{f}$ show the movement of the stream back and forth from the center to the right. Maximum deflections of up to one inch are evident from the ruler. 
Figure 11. Glass Stream Behavior Inside an Insert

At 42.2 Lb/hr Flow and 4 Lbs Surge (0009_6/26/99)

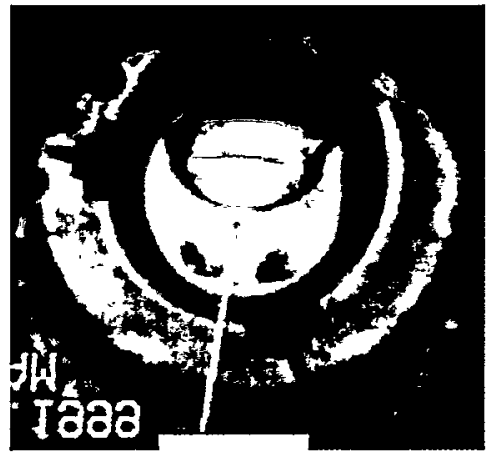

a

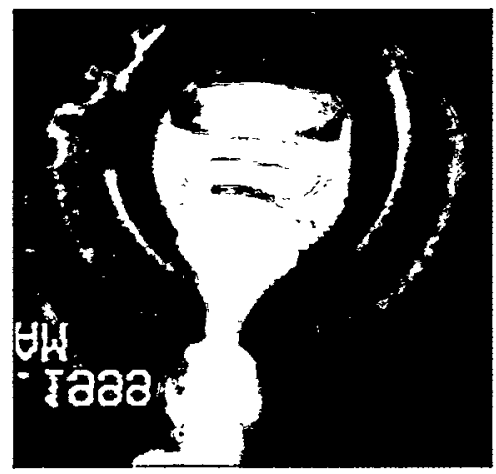

d

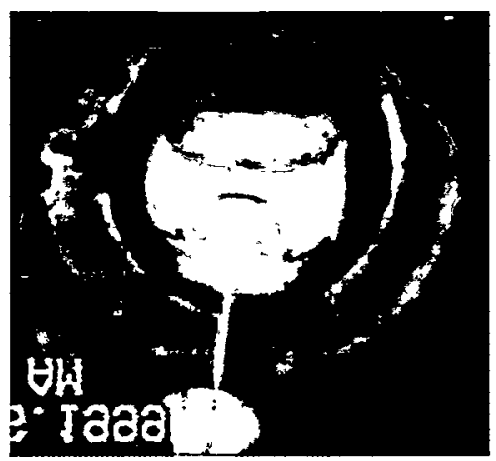

9

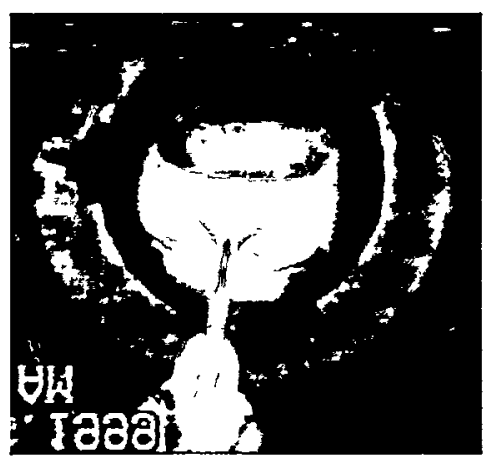

j

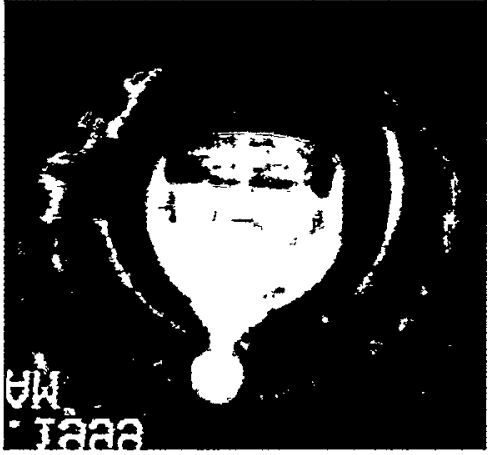

b

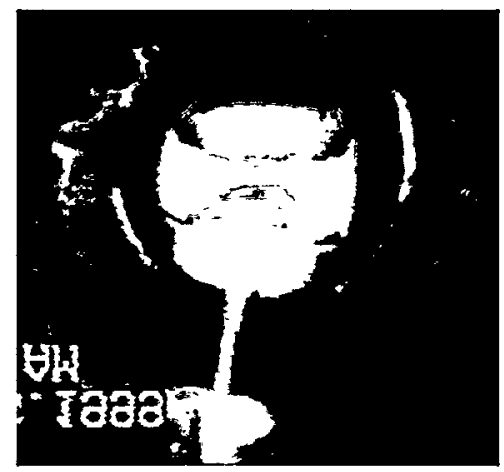

e

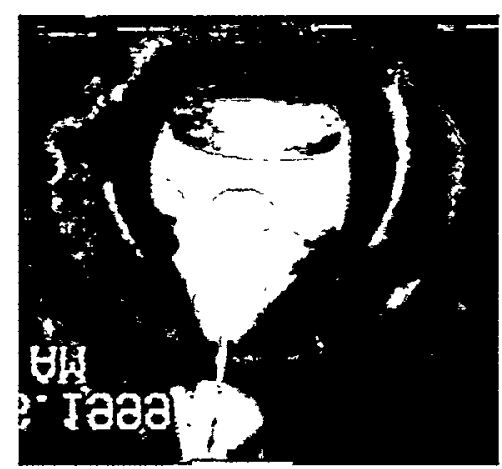

h

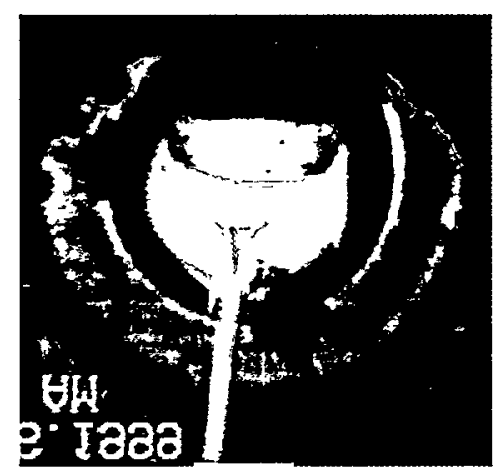

$\mathrm{k}$
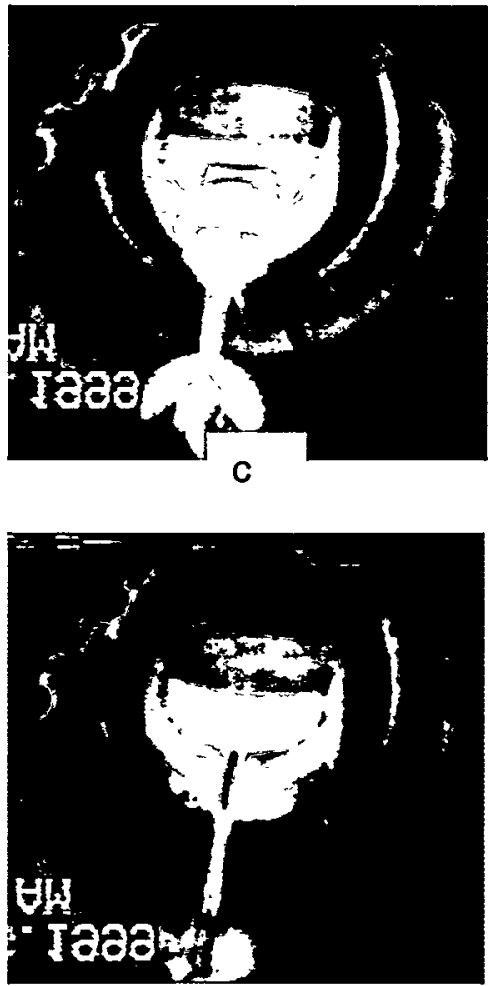

Hin

Tatopy

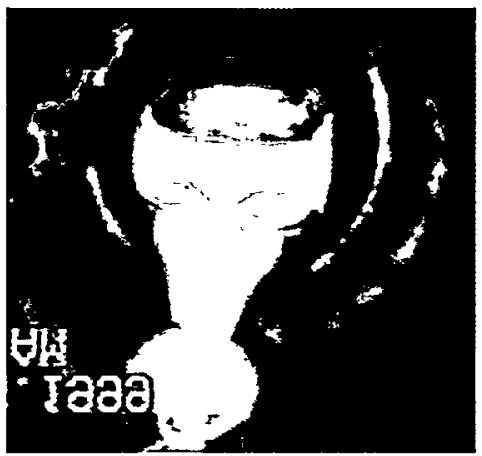

i

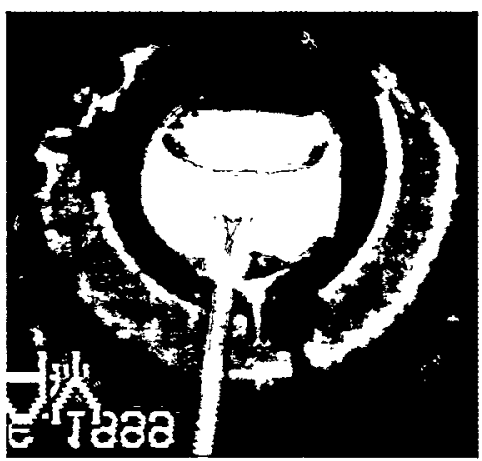

1 
For the surge test shown in Figure 11, the steady state flow rate was $42.2 \mathrm{lbs} / \mathrm{hr}$ where the previous flow rate was higher. Figure 11a shows the initial flow separating from the insert knife-edge. The surge front due to a 4 pound drop test can be seen inside the pour spout. In Figure $11 \mathrm{~b}$, the stream deflects inside the insert and hits the insert wall. Glass then collects, and interrupts the flow out of the insert. Spreading of the glass downward is aided by gravity while capillary forces are limited in the lateral direction. This causes rounding of the stream and an increase in height, which might also be aided by surface tension. The leading edge of the surge front reaches the insert knife-edge and deflects backwards. Figure 11c shows the deflecting stream hitting the cold collected glass on the insulation opening. In Figure 11d, the increase in level in the pour spout results in continuous wicking. In Figure 11e, the pour spout level has decreased to a medium level and a meniscus forms in the glass stream inside the insert. The glass then separates from the pour spout knife-edge (Figure 11f) and a repeated wicking occurs with a medium frequency, repeating the alternate glass separation from the pour spout and insert knife-edges. Figures $11 \mathrm{~g}-11 \mathrm{i}$, the level in the pour spout has significantly decreased but surging still occurs inside the insert although with a longer period. In Figure 11i, one last large surge occurs. The glass then finally separates from the pour spout knife-edge (Figure 11k). From Figures $11 \mathrm{k}$ and 111 , one can see a second stream swing from side to side behind the main stream. This is similar to what was observed in the DWPF Pour Spout.

Figure 12 Glass Stream Deflection as Recorded by the Side Camera During a $4 \mathrm{lbs}$ Surge at $41.5 \mathrm{lbs} / \mathrm{hr}$ Flow (00:09-6/26/99)

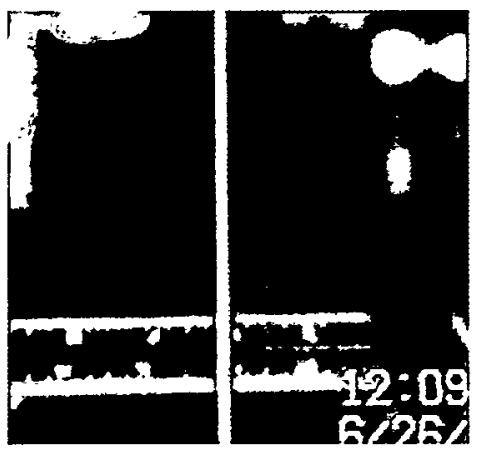

a
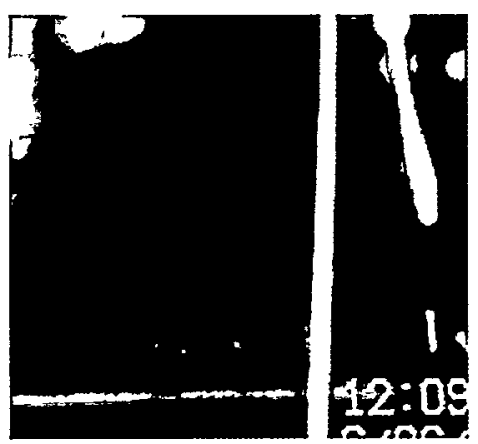
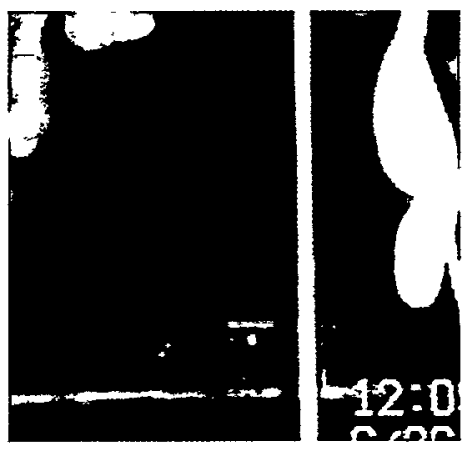

b

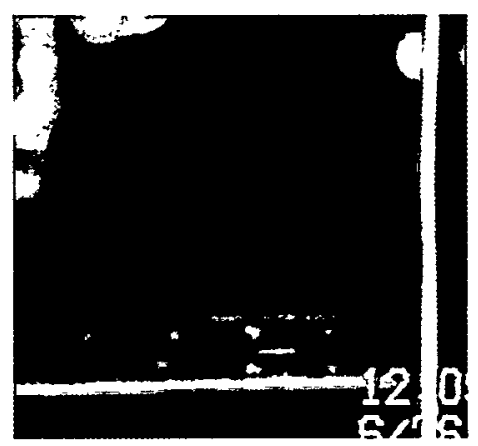

e
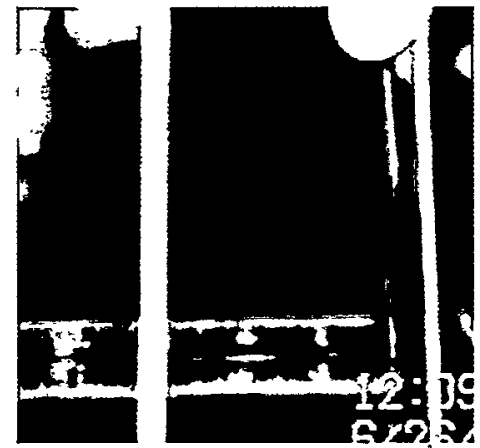

C
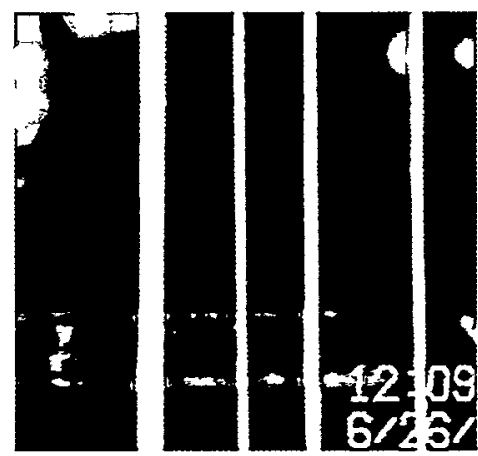

f 
Figures 12a-12f show some video clips of the glass stream as it swings backwards and forwards repeatedly during this test. The last figure shows multiple streams resulting from the last large wick.

The general pattern of wetting behavior in the spout is compatible with the surface tension measurements of molten glass on oxidized Inconel $690^{\mathrm{mm}}$. Under steady state conditions, the glass forms a thin, concave crescent-shaped ribbon approximately half way around the spout. At the knife-edge the glass collects with surface tension pulling the stream into a roughly circular cross section. The wetting is not instantaneous, and during surging the main flow of the glass can form a thick convex spine along the centerline of the wetted area. At very high flows the convex section can bulge and separate from the knife-edge, resulting in very erratic flow.

The junction between the spout and the insert is critical for control of surging conditions. If there is mismatch, the stream can separate from the insert and drop from the knife-edge instead of the insert. Later the stream may reattach itself to the insert and accumulate material, thereby, resulting in an erratic slug of glass.

\section{Pour Spout Geometry Effects}

- Eroded Knife-edge

This testing is being conducted by Florida International University and will be reported separately.

\section{Replacement Spout}

- Design study of replaceable heater

The thermal data from the DWPF Pour Spout Test Stand is being evaluated to determine what changes are practical. An auxiliary heater near the bottom of the spout that would level out temperature gradients in the area of the insert would be advantageous.

- Design study of replaceable riser/pour spout

Based upon discussions with DWPF, it is unlikely that major changes to the spout are practical. Minor changes to the shape of the serpentine heater may improve thermal gradients at the bottom of the spout.

- Design study of replaceable knife-edges

An alternative knife-edge design should be developed that is specific for the use of inserts. This would feature positive alignment between the spout and the insert, and minimum disruption of the glass flow at the junction. The design would also need to accommodate geometry changes resulting from spout oxidation and corrosion.

- Engineering test of replaceable knife-edges

Tests of alternative designs can be conducted in FY 00. This could include a short insert, which effectively repairs knife-edge corrosion provided that gauging of the worn spout can be conducted. Photographic methods hold the best promise for this since they are non-intrusive. Simple imaging methods have been effective on the DWPF Pour Spout Test Stand. 


\section{Pour Spout Inserts}

- Insert nominal configuration

Testing was conducted under a range of flow conditions and temperatures. Results are reported above.

- Insert improved configuration

Testing will be conducted in FY 00.

- Effect of insert/knife-edge gap

Testing will be performed in FY00.

- Effect of variable gap (cocked insert)

Testing has been done with the insert in a "cocked" configuration. The flow patterns were normal but noticeable rippling of the stream occurred at the junction where the knife-edge and insert met. A small amount of glass flowed down the back edge. The viscosity of the glass that adhered to the lower portion of the spout was typical of DWPF indicating the temperature of this region is similar to DWPF conditions.

\section{Alternative Spout Designs}

- Plug/Seat wetted tube knife-edge - horizontal

The drain on the primary tank was tested and lacked sufficient heat. Gaps in the insulation were plugged to reduce the "chimney" effect of cold air flowing past the spout and cooling it. However, the heater was still insufficient to heat the valve assembly. A propane burner is used to provide sufficient heat to initiate pouring. The plunger / valve seat system used in this arrangement is good at controlling glass flow when sufficient heat is available.

- Plug/Seat wetted tube knife-edge - vertical

Superheater drain. The cylindrical heater assembly on the drain burned out during initial operations and needs design changes to be more remoteable. The original heaters were replaced with larger diameter, longer, and more powerful heaters. Pour rates were achieved between 20-300 lbs/hr.

- All Inconel $690^{\mathrm{rM}}$ overflow spout

The Inconel $690^{\mathrm{TM}}$ overflow connecting the Primary Tank to the Superheater operated satisfactory. The spout is restrictive to flow and allowed an excessive inventory of glass to build up in the Primary Tanks. This resulted in glass leakage at the section of the Superheater which mates to the Primary Tank. This condition would be improved by better instrumentation of the Primary Tank and Sùperheater glass levels, a less restrictive overflow spout, and increased freeboard in the Superheater. 
- Comparison of initial to final dimensions of tank, agitator, spout and similar components

Initial dimensions of the Primary Tank wall thickness, agitator dimensions, and dimensions of the plugs in valves for the Superheater have been recorded for comparison to after test dimensions. Some corrosion has been noted at the junction of the agitator and the drive shaft. This corrosion is attributed to molten salt attack of the copper base alloy of the drive shaft.

- Alternative material coupon tests

SRTC will evaluate potential alternative alloys before making coupons.

\section{Noble Metal Behavior and Effects}

Noble metal effects in other melter systems have been discussed at a technical exchange held in Augusta, GA May 4-5, 1999. The results of the workshop are being reported separately by PNNL.

- Sedimentation in Stirred melter

- Agitator suspension of insoluble particles 


\section{Assistance to other programs}

The Pu Disposition Program is developing means of immobilizing and disposing of low-grade scrap plutonium. The Pu Can in Canister program is researching the fabrication of ceramic watse forms and their potential disposal in DWPF canisters. In FY99 the Pu Can in Canister program used the Stirred Melter at Clemson Univ. to pour trial cans to verify the ability of glass to flow around the racks holding the $\mathrm{Pu}$ canisters. Racks and non-radioactive surrogate Pu pellets were used. Preliminary results are that the glass flow was satisfactory leaving a minimum of gaps or voids. The DWPF spout was removed for these tests. The photos below show a full-size DWPF canister being filled, and an inside view of the glass stream forming a glass pool that surrounds the cans. In addition to the equipment and trained personnel, most of the necessary procedures for the glass melting and pouring were used directly from those generated in TTP SR1-6-WT-31.
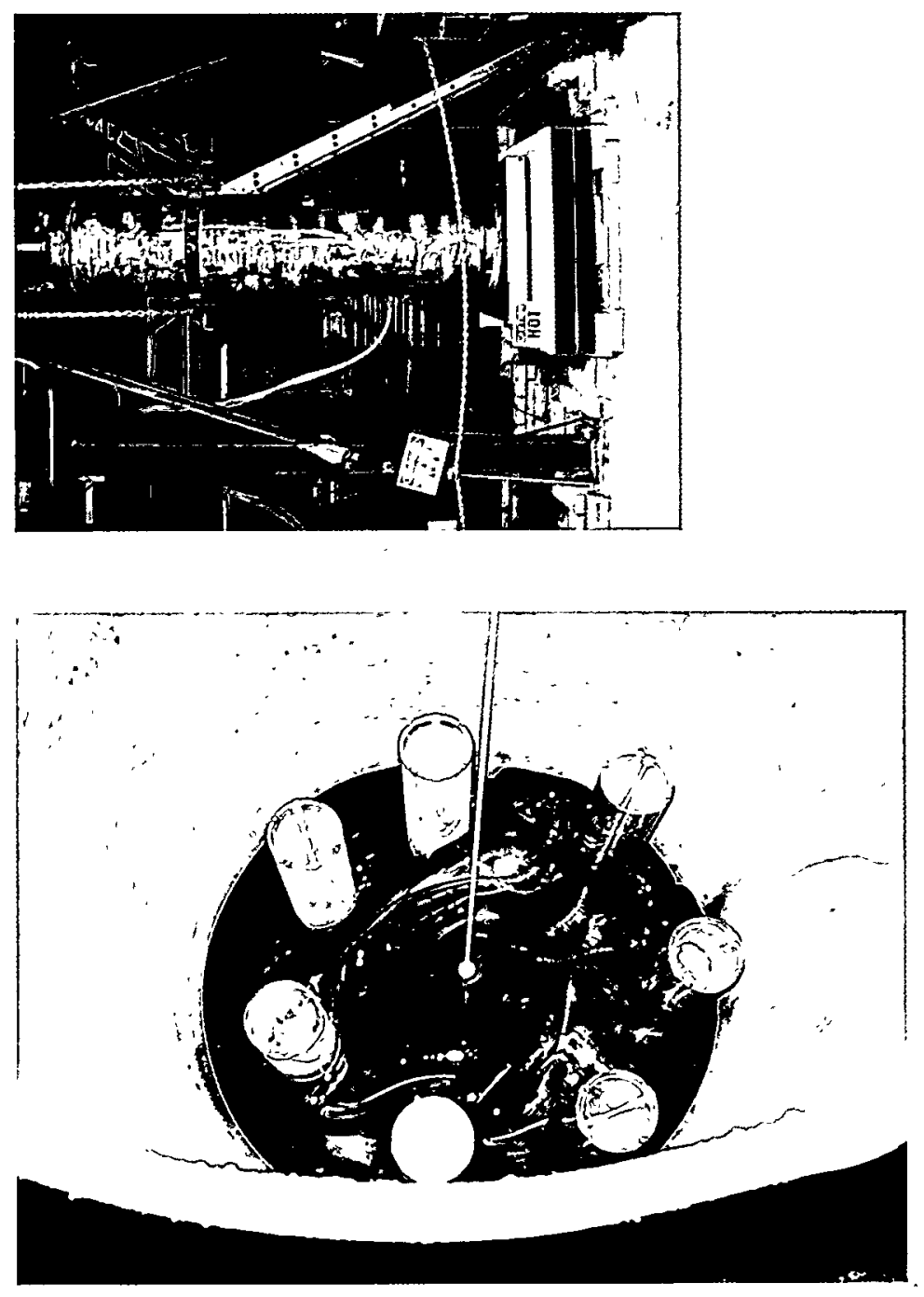

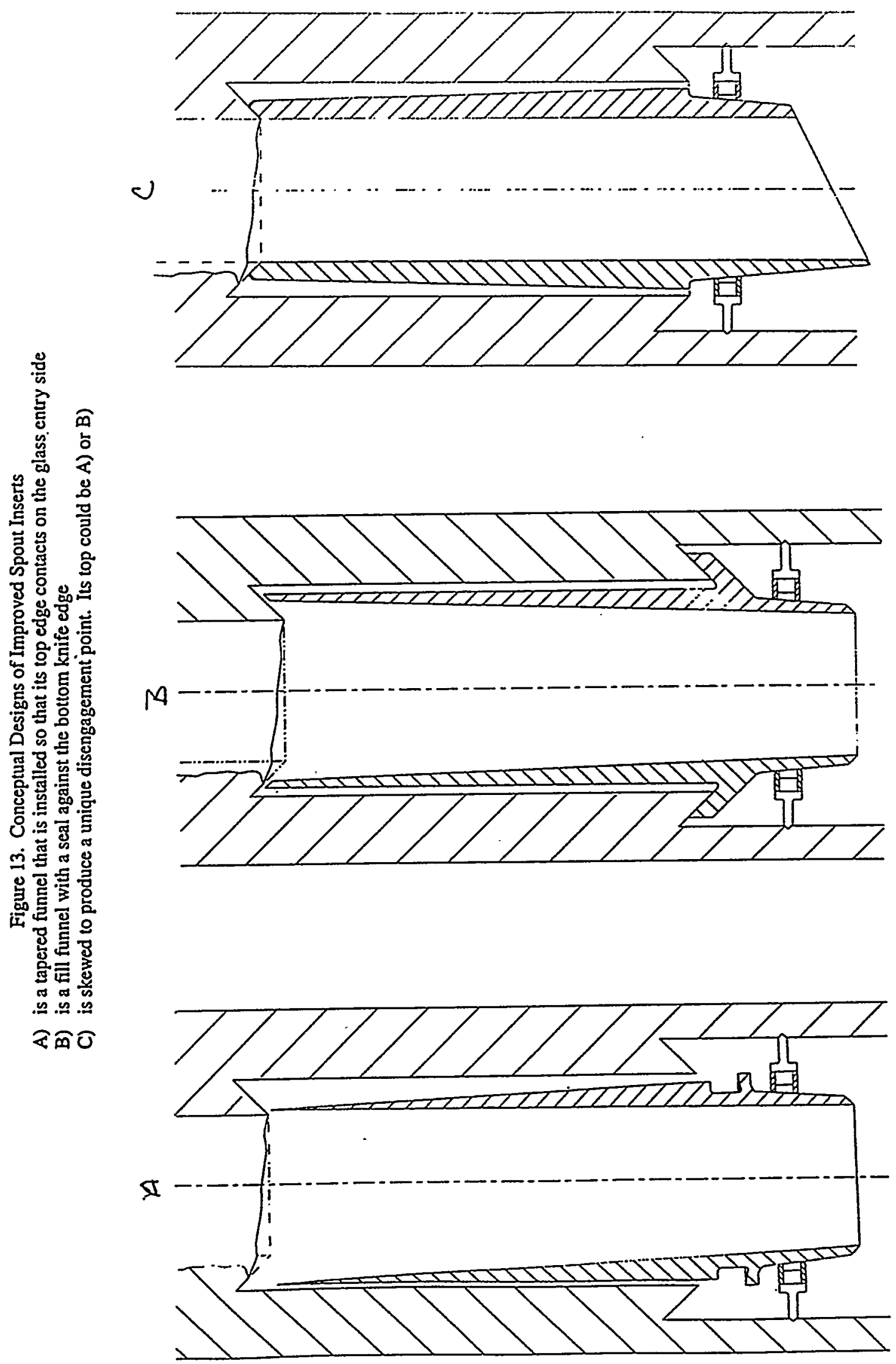


\section{CONCLUSIONS}

End effects at the bottom of the Riser and radiative heat loss from the end of the spout cause the lower portion of the Riser to be cold enough that glass sticks to it and accumulates. Depending upon specific circumstances the cold glass may drip like cold tar or accumulate on the Riser. Accumulated cold glass tends to devitrify (changing from glass to a combination of glass and crystals). Once devitrified, the glass is more difficult to remove mechanically and generally stops flowing. In DWPF, this led to reboring of the pour spout to produce knife-edges in the hotter regions of the temperature gradient, thereby improving the glass separation from the metal tube. Future tests will be conducted with input power settings to the heating zones of the pour spout, to determine what localized power is required to maintain uniform temperatures.

The current combination of a large diameter Bellows Shield and centering of the Bellows Shield on the Normal Disengagement Point (with clearances to allow the pour stream to wander around the bore of the Pour Spout) requires a large diameter transition piece. The transition piece between the Riser and the Bellows, which aggravates thermal gradients in the Pour Spout. If the location of the Disengagement Point can be controlled such that it is a Unique Disengagement Point, then this would permit reduction of the bore diameter in the thermal insulation between the bottom of the heated Pour Spout Section and the Bellows Section. Radiative heat loss could probably then be reduced by $50 \%$ or more. An electric guard heater at the bottom of the Spout would reduce the accumulation of glass in the Spout and Insert. It would be a more effective tool than periodic cleaning with an insulated cup, since it would ad heat, and could be continuously operated.

The existing Riser and Spout Heaters have operated for 5 years in DWPF without failure, therefore there is an incentive to keep the basic existing design. Thermal gradients could, however, be improved by changing the with of the Spout Heater at the bottom end to increase heat production in the cold end, and decrease the heat produced at the center, where temperatures are close to the Inconel operating limit. Review of the mechanical assembly drawings of the Spout indicate that the Spout Heater, and perhaps the Riser Heater, could be modified to be replaceable. The ceramic insulators would be made longer, and the heaters fabricated so that the power leads come out the end of the heater.

Long term programs should include thermal modeling, fluid modeling, and physical testing to improve this portion of the design.

One of the major current findings of the team is a better understanding of the surface effects of the Pour Spout and the glass. Normally, these effects are rarely considered since they are difficult to monitor and control at molten glass temperatures. Normally stronger forces overwhelm their effect. However, in the pour spout the glass flows down a vertical tube. Therefore small forces such as surface tension or irregularities in the shape or finish of the surface, can spread the glass stream out or cause it to shift direction. We are indebted to the work of J. Sproull and C. Cicero-Herman who worked with the New York State College of Ceramics to better define surface tension and viscosity effects. They found that the glass wets both unoxidized and preoxidized Inconel $690^{\mathrm{TM}}$ at very low contact angles (typically 4 to $40^{\circ}$ ). This effect has been confirmed in the DWPF pour spout with radioactive glass which appears to be totally wetted in the upper section. Also in videos this effect has been seen to form ribbons along the knife-edge rather than pencil shaped streams. The ribbons may result in drips from different portions of the ribbon, or even multiple streams or oscillating streams. The ribbon pouring has been simulated on a physical model and appears to have several forms of instabilities which could distort the shape and location of the glass stream. Molten salts have also been found in the melter pour spout and their effect on the wetting characteristics has not been determined. Molten salts are possible causes of corrosion in the Pour Spout, leading to changes in geometry which cause pouring difficulties. The combination of surface tension effects and crystallization in the upper section has been proven to result in a stable glass film up to a $1 / 8$ of an inch thick all the way 
around the spout. These effects reinforce a new design requirement of a Unique Disengagement Point to control the separation of the glass from the Pour Spout.

A Unique Disengagement Point should have at least four design elements. First, the design should be insensitive to surface effects, leading the glass to flow to a single point and disengage from that point whether the spout is clean or fouled, oxidized or unoxidized, eroded or freshly machined, and not sensitive to fluctuation in surface tension and wetting angles. Thus, the design needs the second criteria, a force to restore the flow down the pour spout to the vertical line closes to the melt chamber. This might be accomplished by inclining the bore slightly to produce a trough with gravity and the curvature of the bore producing the restoring force. The third criteria is to have the final disengagement point as the lowest point in all directions, with a slope from other surrounding areas to be determined by future tests. This feature tends to gather back any wandering portions of the stream traveling down the tube and therefore, stabilizes the cross section shape and size of the stream. The fourth feature is to have the cross section of the metal near the disengagement point as symmetric as possible. This feature is to introduce symmetry near the Disengagement Point to minimize lateral wandering of the stream caused by velocity, viscosity, and momentum gradients as the glass transitions from being guided by the metal to a free falling condition. Conceptual designs are shown in Figure 13.

Erosion or corrosion of the Pour Spout by molten glass has worn the upper knife edge, and may have worn a channel in the side wall of the Spout. This wear has been making it increasingly difficult to seat the insert against the spout. A short knife edge replacement that will seat securely against the side wall should be developed to provide a new mating surface for future inserts.

\section{Future Operations:}

FY00 Tasks will include: Integrate results from small scale melter tests at FIU which are evaluating the effects of pressure perturbations, pour spout temperature, and knife edge design and dynamics with SRS design efforts to improve melter insert designs. The Clemson testing will identify key parameters and designs, and test a prototypic pour spout at expected glass pour rates. Testing with modified pour spout geometries was not initiated during FY99 due to design issues with the test melter discussed above and the need to complete the small scale testing at FIU. These tests will be conducted during FY00. SRTC will provide technical staff to support continuous operation of the melters to accomplish the test objectives in this task. Where possible, cognizant staff involved in the program and trained on the equipment will supplement the SRTC technical support (e.g. INEEL, FIU, PNNL, and South Carolina State University principal investigators). Test or experimental plans will be prepared for each melter run and will be reviewed by the non-lead members of the technical team.

Task A.1. Pour Spout Testing will initiate testing on pour spout inserts integrating SRS design, FIU results and key performance parameters to provide design and operational input to DWPF for future inserts. Identify key operational parameters such as pour spout heater requirements to ensure steady flow.

Task A.2. Noble Metals Testing will define the testing required to improve the DWPF melter design. Ensure that the design addresses the potential effects of maximum flowsheet levels of noble metals. Test design concepts and document results. Develop recommendations for improvements to DWPF melter 3 design.

Task A.3. DWPF Melter Chemistry and Idaho will be evaluated and expanded to include more definitive chemical control of the variables that most impact potential melter foaming, gas evolution, and component dissolution into the melt (redox, oxyanions, fluorine volatility, cesium volatility, etc.) The extent of redox control for both Idaho and DWPF will be developed in this task (impact of foaming, gas evolution and 
composition will be evaluated to determine the relationship to foaming and feed control). Melter runs with increased $\mathrm{Zr}$ and $\mathrm{CaF}$ will be made to validate the results of formulation development in task 99073 , addressing issues related to both phase separation and to viscosity. The higher $\mathrm{Zr}$ testing is also relevant to Hanford waste immobilization. Feed formulations tested on a crucible scale in 99073 will be piloted in this task. Integrate the chemical modifications with the DWPF integrated material balance prior to testing. Recommend process flowsheet modifications. Utilize this data as input to the INEEL's flowsheet development. Jointly with INEEL and PNNL, evaluate the applicability of the cold crucible melter being tested and developed by the French and Russians. SRTC and INEEL will share melter run support as required for both DWPF and INEEL tests.

\section{FY00 Milestones:}

A.1-1 Issue letter report transmitting conceptual and assembly drawings on the DWPF pour spout heaters

Develop conceptual and assembly drawings for the pour spout heater modifications based on discussions with PNNL and review of the Clemson prototypic pour spout performance. SRTC will review the drawings prior to acceptance. (PNNL - Lead)

A.1-2 Issue report on design recommendations for melter pour spout and riser heaters $6 / 30 / 00[00]$ Document testing on SRS pour spout insert configurations, integrate the results from FIU and recommend a path forward to DWPF. Document the performance of the riser heaters and modifications that will improve glass flow and dynamics through the DWPF melter. Identify improvements that may be applicable to DWPF Melter \#2. PNNL will provide technical review of the recommendations prior to release. (SRTC lead)

A.2-1 Issue letter report on noble metals settling estimates

9/30/00[OO]

Based on previous data and the results of the EMSP tests, provide estimates of noble metals settling and guidelines for an operational test. This work will leverage the EMSP task with PNNL on noble metals behavior in melters and will provide a test basis for a melter test at Clemson. SRTC will utilize the results in developing a melter test for noble metal behavior. (PNNL - Lead)

A.3-1 Issue report on high temperature material compatibility tests

$6 / 30 / 00[0 O]$

Perform high temperature material compatibility and corrosion testing for refractory and electrode materials exposed to INEEL surrogate glass formulations at high processing temperatures. This should be reviewed and coordinated with INEEL, SRTC, and the research team on 99073. (PNNL - Lead)

A.3-2 Complete Idaho melter testing using candidate glass formulations resulting from task 99073

The candidate glass formulations will be sponsored by both EM-50 and Idaho's EM-30.

9/30/00[HQ]

Perform treatability melter tests using candidate glass formulations to compare durability and processability properties, determine melt rates, monitor/determine off-gas speciation, verify materials of construction compatibility tests (A.3.1), and evaluate optimal processing temperatures (criteria includes waste loading, volatility, corrosion, processability, etc.). The test plan will be coordinated and reviewed by SRTC and PNNL. (INEEL Lead)

A.3-3 Issue report on crucible and melter tests on sodium bearing and calcine wastes. .

9/30/00[OO]

Perform testing on sodium bearing wastes or calcine to estimate composition boundaries using laboratory melts, small melters or pilot melters. Evaluate redox, application of reductants to increase melt rates, devitrification, off-gas speciation analysis, glass durability, and corrosion of melter 
materials. Scoping test objectives will be collaborated between INEEL, PNNL, and SRTC. (INEEL- Lead)

A.3-4 Issue report recommending path forward on high temperature testing 9/30/00[OO] Review the results of higher temperature testing and recommend a path forward for INEEL feeds. This task is co-sponsored by Idaho EM-30 which will include identification of test objectives that will support review of Russian and French Cold Crucible Melters. Coordinate with SRTC and PNNL and the work 99073. (INEEL- Lead)

\section{ACKNOWLEDGMENTS}

The authors would like to express their appreciation to the following persons for their contributions to this test program:

D. Erich, J. Harden, T. Pruett of Clemson Environmental Testing Laboratory; Marvin Trimm; Vernon Bush, Victor Buch; George Adondakis; Nick Odom; Tim Jones; Don Miller; Cary Miller; Paul Burket.

\section{REFERENCES}

1. “Kepner-Tregoe Final Report”, WSRC-OPS-DTP-970070, J. Morin, April 29,1997.

2. Subtask C, “Second Generation DWPF Melter”, TTP\# SR1-6-WT-31, January 15, 1999.

3. “Tạk Technical and QA Plan: Melter Performance Improvements", WSRC-RP-99-00326, D. F. Bickford and J. C. George, June, 1999.

4. "Experimental Test Plan for Improve Performance of HLW Melter Test (U), SRT-GFM-99-0017 Rev. 0, D. R. Bickford and J. C, George, June 16, 1999.

5. “DWPF Melter-1 Pour Spout Insert (U)”, WSRC-OPS-DTO-9X00XX, D.C. Iverson, January 28, 1996.

6. "Evaluation of Materials and Surface Treatments for the DWPF Melter Pour Spout Bellows Protective Liner (U)"WSRC-TR-97-0113 Revision 0, K.J. Imrich, D.F. Bickford, G.G. Wicks.

7. "Metallurgical Evaluation of an Inconel 690 Insert from a Radioactive Waste Glass Melter Pour Spout", K. J. Imrich and D. C. Iverson. 
WSRC-TR-99-00305, Rev. 0

August 30, 1999

\title{
Appendix A
}

\section{Numerical Modeling of DWPF Melter \\ Glass Pour Process}

August 20, 1999

\author{
By: $\quad$ H. Naseri-Neshat, 786-6A \\ South Carolina State University \\ Site Technical Representative: \\ H. N. Guerrero \\ Savannah River Technology Center \\ Aiken, SC 29808
}

\section{Summary}

Three-dimensional modeling of the DWPF melter glass pouring process was performed using the FLUENT Version 5.0.2 computational fluid dynamics package. Solutions were obtained for threedimensional glass flow for an average inlet velocity of $0.055 \mathrm{~m} / \mathrm{s}$ corresponding to a mass flow rate of $0.009 \mathrm{~kg} / \mathrm{s}$ (about $150 \mathrm{lbm} / \mathrm{hr}$ ). Surface tension effects with contact angles of $30^{\circ}$ and $75^{\circ}$ were examined. Different models were studied, all with a 2-in diameter vertical portion of 2-6 inches length, followed by an expansion to 3 -in diameter pipe through a $45^{\circ}$ wedge. Finally, a 3 -in diameter section of 3-6 inches long was used for the downstream of the knife-edge. Different lengths were adopted due to memory limitations, and also to assure achievement of fully developed flow in each section. The results closely match those of experimental outcomes with regard to film thickness and contact angles. The glass stream did not break-up as observed with previous analytical results. The section before the wedge needs to be at least 6 inches long to achieve fully developed flow. Because of the imposition of an outlet boundary condition, the length of the downstream section affects the deflection of the glass stream. This section should be modeled 6-9 inches long to minimize the effects of an outlet boundary condition. The best outcome will be achieved if a 2-in long transition from the riser (4-in diameter pipe) is modeled before the 9-in vertical section (2-in diameter pipe), followed by 6 -in length downstream from the upper knife edge (transition to 3-in diameter pipe), and finally a 6-in length after the second knife edge and the expansion to 4-in diameter pipe. There was a marked difference between the two contact angles studied. For the $30^{\circ}$ contact angle, the glass free surface on the spout wall was flat, while for the $75^{\circ}$ contact angle, the glass surface became convex. 


\section{Introduction}

The FLUENT Volume of Fluid (VOF) Free Surface Model was used to simulate the DWPF glass pouring process. In the VOF model, the fluids are assumed to be immiscible with an interface between them. Diffusion across the interface is prevented. The fluids share a single set of momentum equations, and the volume fraction of each of the fluids is tracked throughout the domain. FLUENT is a pressure based, segregated, finite volume method. In the segregated approach, each conservation equation is solved separately in a sequential manner (in this case, the continuity equation and momentum equations). For these studies the temperature of the glass was constant and the energy equations are not incorporated in the solution analysis. The adhesion of the glass to the walls around the knife-edge, and the deflection or breaking of the glass flow just downstream of the spout were of interest. Because of the limitations on computer memory, the model was created such as to produce the most accurate results possible in region of interest. A transient solution was also obtained for the $30^{\circ}$ contact angle to study the effects of a surge in flow. The inlet velocity was increased by four times and then reduced back, all in four time steps of 0.1 second each. The resulting wave propagates smoothly through the 2 -in diameter pipe and then downstream of the flow past the knife-edge.

\section{FLUENT Model Description}

The region just before and after the first knife-edge of DWPF glass Melter (Figure 1) arrangement was modeled using the actual spout diameter size of 2 inches. The bending and adhesion of the glass to the walls in the immediate area of the knife-edge were important factors in developing the model. Due to memory limitations and symmetry, only a $60^{\circ}$ segment of the pipes was modeled. To capture the glass adhesion effects, a finer grid mesh was constructed in the two vertical narrow band regions where the glass was expected to wet the wall in the upstream region of the knifeedge. A fine mesh was also used near the knife-edge area where it is expanding.

The glass was modeled as the secondary phase, and the air as the primary phase. The surface tension and wall adhesion options of the VOF method were invoked. The domain was assumed to be initially filled with air, so a volume fraction of one for air was patched to the entire domain at start-up. To initiate the solution, and improve convergence, a layer of glass with a cross section approximating the final glass profile was patched in the entire upstream portion of the knife-edge. This was to prevent air pockets forming between the glass stream and the walls as the glass is flowing down. Presence of air pockets severely hampers the convergence, and the number of iterations for each time step increases several times. A time step of $0.001 \mathrm{~s}$ was arrived at, resulting in 10-25 iterations per time step. 


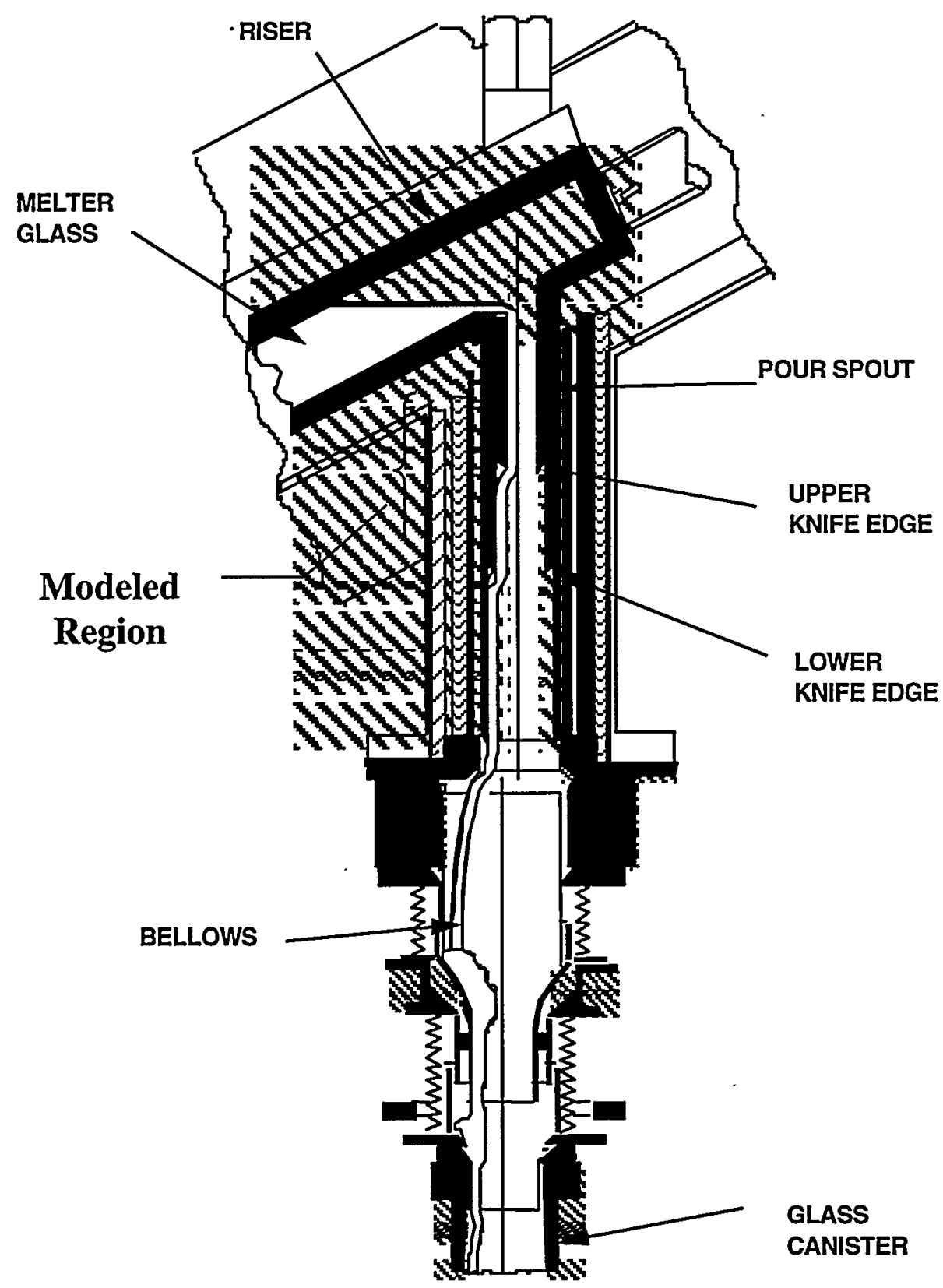

Figure 1. DWPF Melter

To better approximate the inlet velocity profile, the inlet area was divided into 10-17 narrow strips approximating the experimental glass flow profile so that different velocity magnitudes could be assigned to these inlet areas. To achieve this, a structured mesh was constructed and inlet velocity areas were assigned in the structured FLUENT4.5, then the case was imported to unstructured FLUENT5 (Figure 2). 
The VOF formulation is time dependent. The tracking of the interface between the phases is accomplished by the solution of a continuity equation for the volume fraction of one of the phases. This continuity equation is solved using an explicit time-marching scheme.

The properties used for the glass in each case are:

Density $=2500 \mathrm{Kg} / \mathrm{m}^{3}$

Viscosity $=7$ and $10 \mathrm{Kg} / \mathrm{m} \cdot \mathrm{s}$

Surface Tension $=0.3 \mathrm{~N} / \mathrm{m}$

Contact Angle $=30$ and 75 Degrees

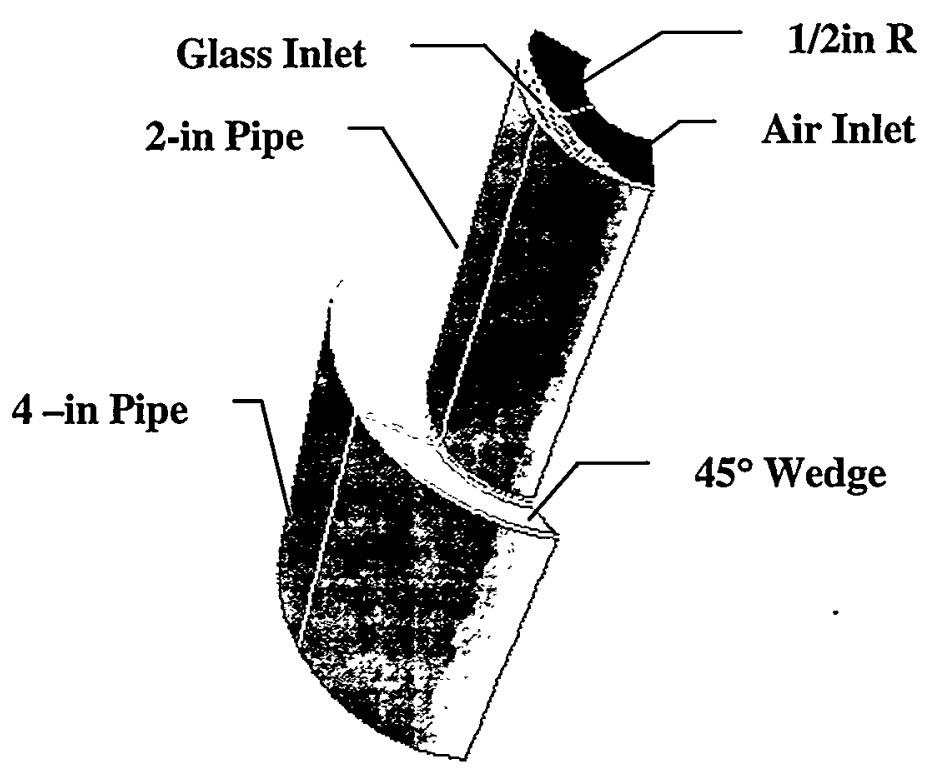

Figure 2. Typical model

Cross Section $=1 / 6$ of Complete Circle

\section{Boundary Conditions}

Inlet BC: An average glass inlet velocity of $0.056 \mathrm{~m} / \mathrm{s}$ was assigned to the inlet areas. The velocity magnitudes in each of the inlet areas were modified repeatedly to produce a glass mass flow rate of about $150 \mathrm{lb} / \mathrm{hr}$. The air inlet velocity was set equal to the glass velocity layer next to it.

Wall BC. Default no-slip boundary condition was assumed for all walls with a contact angle of 30 or 75 degrees.

Outlet BC: The outflow BC was assumed as a pressure outlet.

Gravitational force of $9.81 \mathrm{~m} / \mathrm{sec}$ was applied.

\section{Results and Discussion}

Several 3-D models were studied. For the steady flow cases, there was a need of about 6000 to 9000 iterations to reach steady state. This corresponded to 5 to 8 seconds of flow. For the unsteady step flow, the results of steady flow with 8000 iterations were used for the initial step up of the inlet velocity. The inlet velocity was stepped up to 2 times for 0.01 second and then to 4 times for another 0.01 second. A similar procedure was implemented for the return of the inlet velocity to its original value. 


\section{Case 1:}

Length $=6$ in

$\dot{m}=135 \mathrm{lb} / \mathrm{hr} \quad \bar{V}_{i}=0.0466 \mathrm{~m} / \mathrm{s}$

$\rho=2500 \mathrm{~kg} / \mathrm{m}^{3} \quad \mu=7 \mathrm{~kg} / \mathrm{m} \cdot \mathrm{s} \quad \sigma=0.3 \mathrm{n} / \mathrm{m}$

Contact Angle $=30^{\circ} \& 75^{\circ}$

72000 Cells

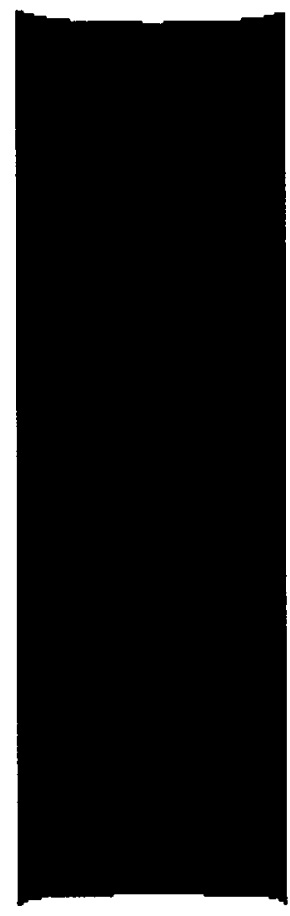

$\theta=30^{\circ}$

Figure 3.a

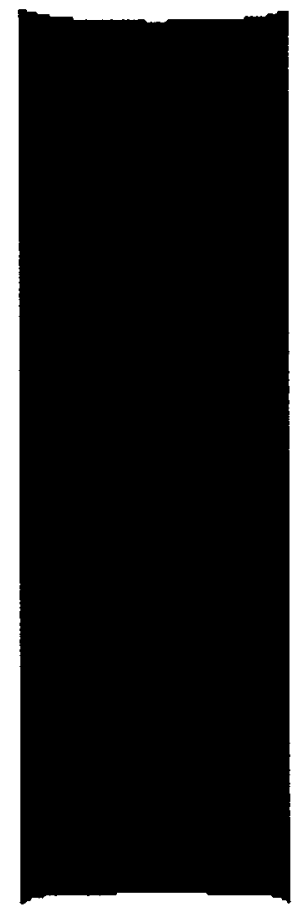

$\theta=7^{\circ}$

Figure 3.b

Figures 3.a and 3.b represent the glass flow in the 2-in diameter spout before the knife-edge. In this model, the glass contact region with the wall for the $30^{\circ}$ contact angle case was fine meshed. The marked difference between the two cases is that the glass/wall contact region for the $75^{\circ}$ contact angle case requires even finer re-meshing than the $30^{\circ}$ case. Figure 3.b shows that about a 4-in long upstream section is sufficient for the flow to fully develop in the $75^{\circ}$ case, while Figure 3.a $\left(30^{\circ}\right.$ case) shows that the flow is still changing, necessitating the full 9-in length of the spout to be modeled. It is possible that for this case, modeling of the 2-in diameter horizontal section before the vertical spout region would be required to achieve a fully developed flow. 


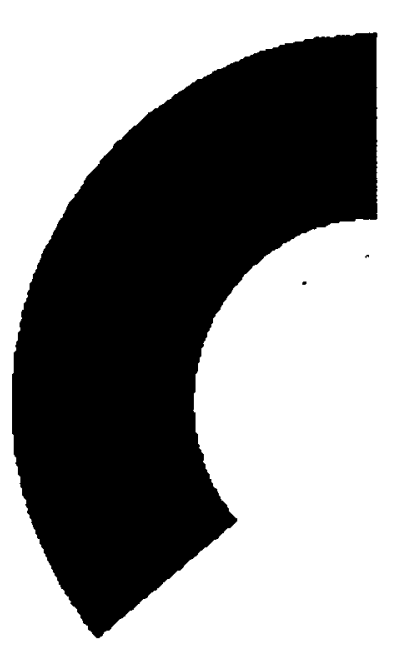

$\theta=30^{\circ}$

Figure 3.c

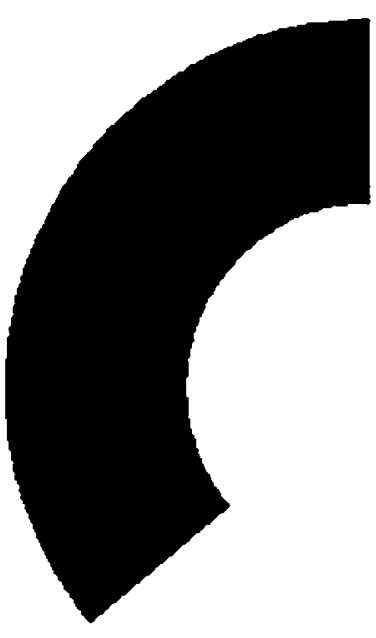

$\theta=7^{\circ}$

Figure 3.d

Figures 3.c and 3.d show the glass flow cross-section at $12.8 \mathrm{~cm}$ below the inlet. 


\section{Case 2:}

\section{Length $=2$ in before the knife-edge +4 in after the knife-edge}

$$
\begin{aligned}
\dot{m} & =147 \mathrm{lb} / \mathrm{hr} \quad \overline{V_{i}}=\mathbf{0 . 0 4 4 5} \mathrm{m} / \mathrm{s} \\
\rho & =2500 \mathrm{~kg} / \mathrm{m}^{3} \quad \mu=7 \mathrm{~kg} / \mathrm{m} \cdot \mathrm{s} \quad \sigma=\mathbf{0 . 3} \mathrm{n} / \mathrm{m}
\end{aligned}
$$

Contact Angle $=\mathbf{3 0}^{\circ}$

\section{Cells}

Figures 4.a and 4.b show the front view and side view, respectively, of the glass flow for the $30^{\circ}$ contact angle. The model shows a slight backward deflection of the glass stream downstream of the knife-edge. Figure 4.b shows some waviness of the stream. Neither situation is a true representation of the actual glass flow. Obviously, the 2-in upstream section is not long enough for the flow to fully develop. The waviness of the stream could be due to the flow not having reached steady state yet. In this model no refining of the mesh in the glass contact region with the walls was done. Also, the inlet velocity was assumed to be uniform.

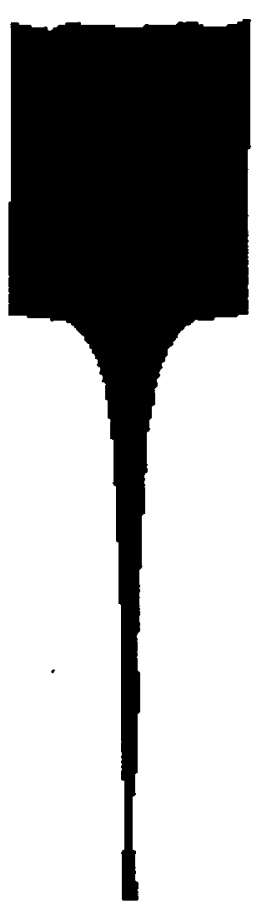

Figure 4.a

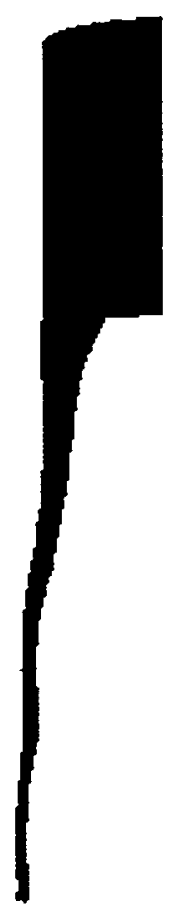

Figure 4.b 


\section{Case 3:}

\section{Length $=2$ in before the knife-edge + 4in after the knife-edge}

$$
\begin{aligned}
\dot{m} & =147 \mathrm{lb} / \mathrm{hr} \quad \bar{V}_{i}=0.0445 \mathrm{~m} / \mathrm{s} \\
\rho & =2500 \mathrm{~kg} / \mathrm{m}^{3} \quad \mu=7 \mathrm{~kg} / \mathrm{m} \cdot \mathrm{s} \quad \sigma=0.3 \mathrm{n} / \mathrm{m}
\end{aligned}
$$

\section{Contact Angle $=7^{\circ}$}

\section{Cells}

Figures 5.a and 5.b show the front and side view, respectively, of the glass flow for the $75^{\circ}$ contact angle case. The glass flow profile looks quite reasonable. The glass-flow after the knife-edge looks vertical, and is aligned with the glass contact with the back wall. However, the 2-in length before the knife-edge is not long enough for the flow to be fully developed. In this model also, there is no refining of the mesh in the glass contact region with the walls. Figure 5.c shows the glass flow just before the knife-edge from the upstream side. The flow has converged to a reasonable result.

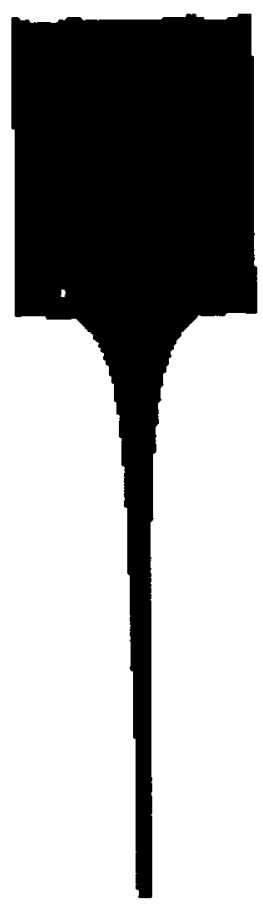

Figure 5.a

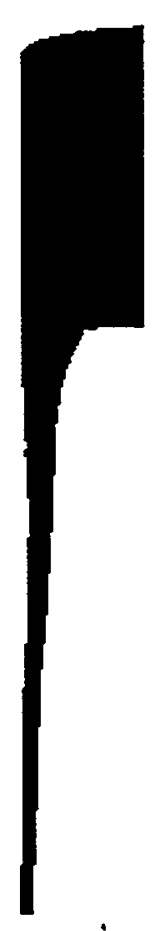

Figure 5.b

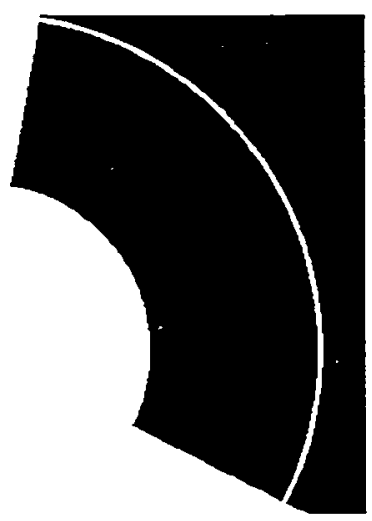

Figure 5.c 


\section{Case 4: Step Flow Modeling of Surging}

\section{4in before the knife-edge +3 in after the knife-edge}

$$
\begin{aligned}
& \dot{m}=148 \mathrm{lb} / \mathrm{hr} \quad \bar{V}_{i}=0.057 \mathrm{~m} / \mathrm{s} \\
& \rho=2500 \mathrm{~kg} / \mathrm{m}^{3} \quad \mu=7 \mathrm{~kg} / \mathrm{m} \cdot \mathrm{s} \quad \sigma=0.3 \mathrm{n} / \mathrm{m}
\end{aligned}
$$

\section{Contact Angle $=30^{\circ}$}

\section{Cells}

Figure 6 (a) through (j) shows the glass flow cross-section at different time steps for the case where a flow surge is modeled. The steady state flow at time of 7.62 seconds was used as the initial condition for the flow surge. Figure 6.b shows the flow after $0.1 \mathrm{~s}$ after the average inlet velocity was increased to $0.114 \mathrm{~m} / \mathrm{s}$. Figure $6 . \mathrm{c}$ shows the flow after it was increased to an average inlet velocity of $0.228 \mathrm{~m} / \mathrm{s}$ for another $0.1 \mathrm{~s}$, corresponding to a mass flow rate of about $600 \mathrm{lbs} . / \mathrm{hr}$. Figure 6.d shows the flow after the average inlet velocity was decreased to $0.114 \mathrm{~m} / \mathrm{s}$ for $0.1 \mathrm{~s}$. Figure 6.e shows the flow after the average inlet velocity was decreased to $0.057 \mathrm{~m} / \mathrm{s}$, which is the original steady state velocity. Figures $\mathrm{f}$ through $\mathrm{j}$ show the flow at $0.1 \mathrm{~s}$ intervals with average inlet velocity of $0.057 \mathrm{~m} / \mathrm{s}$. 


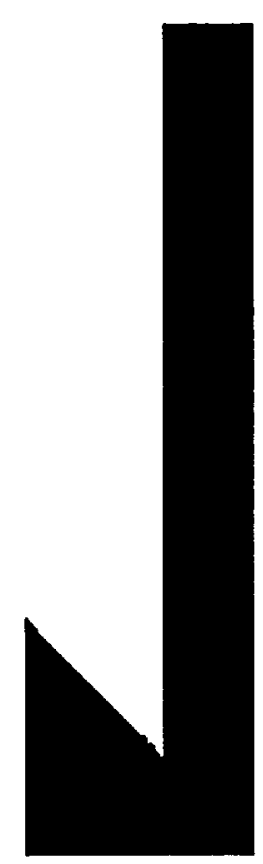

$t=7.62 \mathrm{Sec}$

(a)

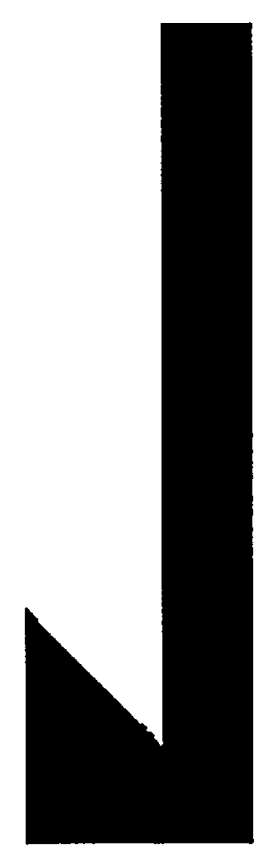

$t=8.12$ Sec

(f)

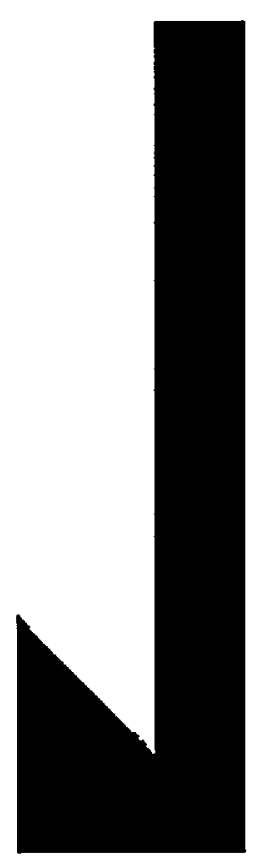

$t=7.72 \mathrm{Sec}$

(b)

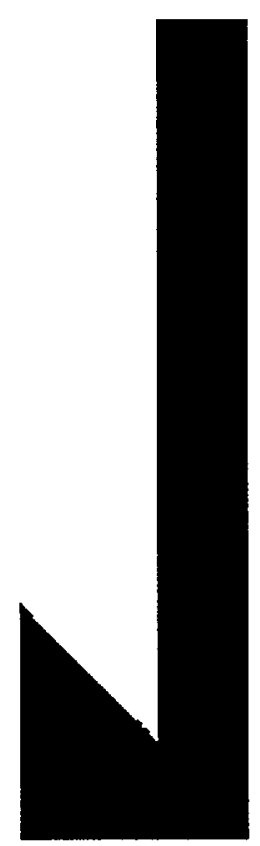

$t=8.22 \mathrm{Sec}$

(g)

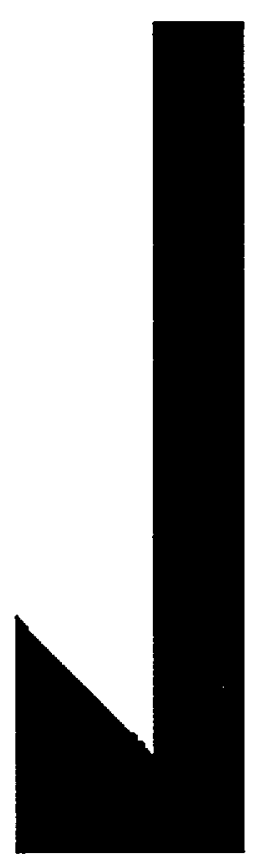

$\mathbf{t}=\mathbf{7 . 8 2} \mathrm{Sec}$

(c)

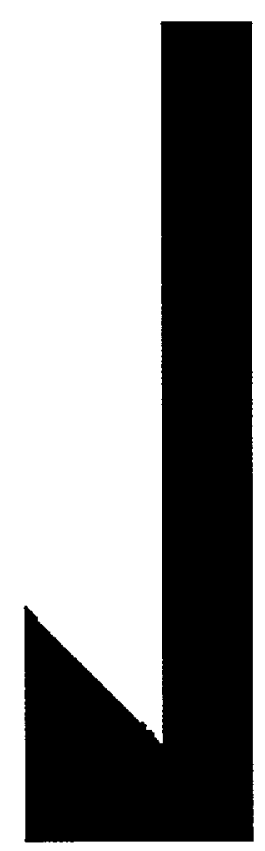

$t=8.32$ Sec

(h)

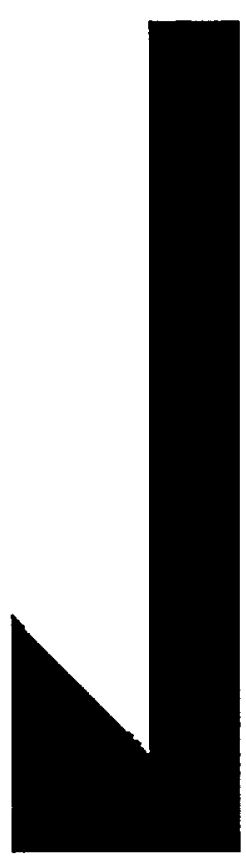

$t=7.92 \mathrm{Sec}$

(d)

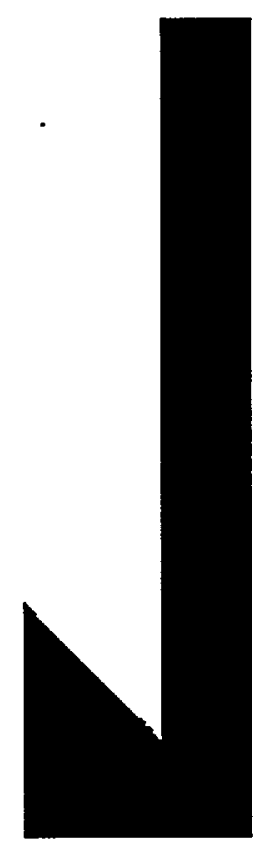

$t=8.42 \mathrm{Sec}$

(i)

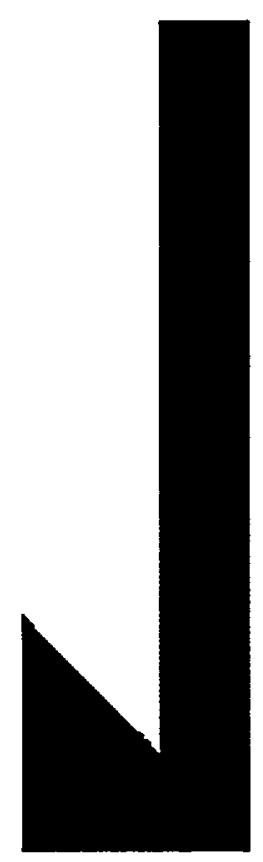

$t=8.02$ Sec

(e)

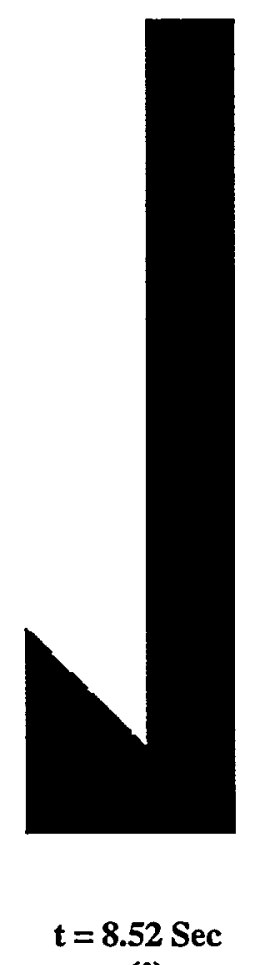

(j) 


\section{Figure 6. Symmetry Plane Cross Section}

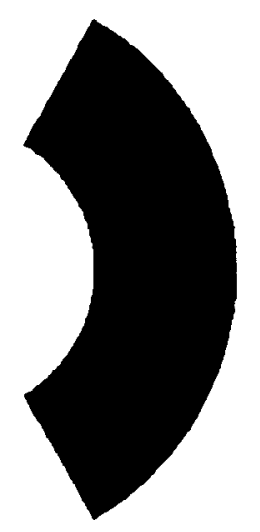

$\mathrm{Y}=0.15 \mathrm{~m}$

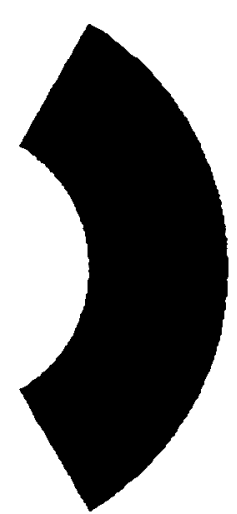

(b)

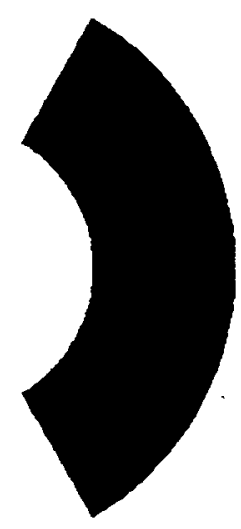

(c)

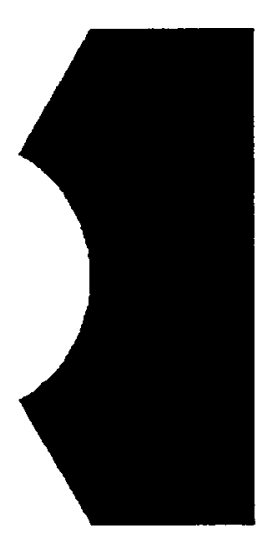

$Y=0.05 m$

(f)

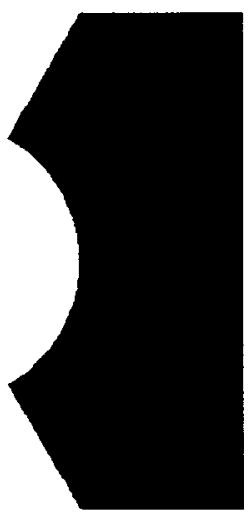

$Y=0.0 m$

(g)

(d)

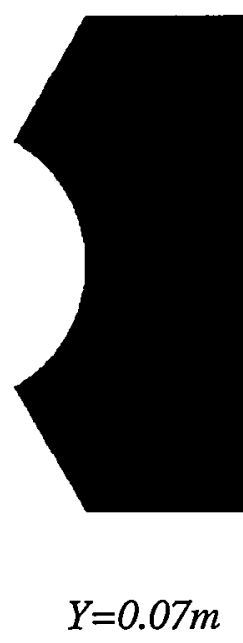

(e)

Figure 7. Glass flow Cross section for $30^{\circ}$ Contact Angle

Figures 7 a through $g$ show the flow cross section at the specified positions at $t=8.02 \mathrm{~s}$, where $y=0$ is below the knife-edge, $y=0.0755 \mathrm{~m}$ is at the knife-edge and $\mathrm{y}=0.15 \mathrm{~m}$ is near the inlet. The downstream flow after knife-edge was not of interest in this study. The section is also not long enough for flow to reach the fully developed state. It remains to be seen what the effects of longer upstream and downstream sections will be on the flow profile. 
Figure 8. Glass Flow, $30^{\circ}$ Contact Angle
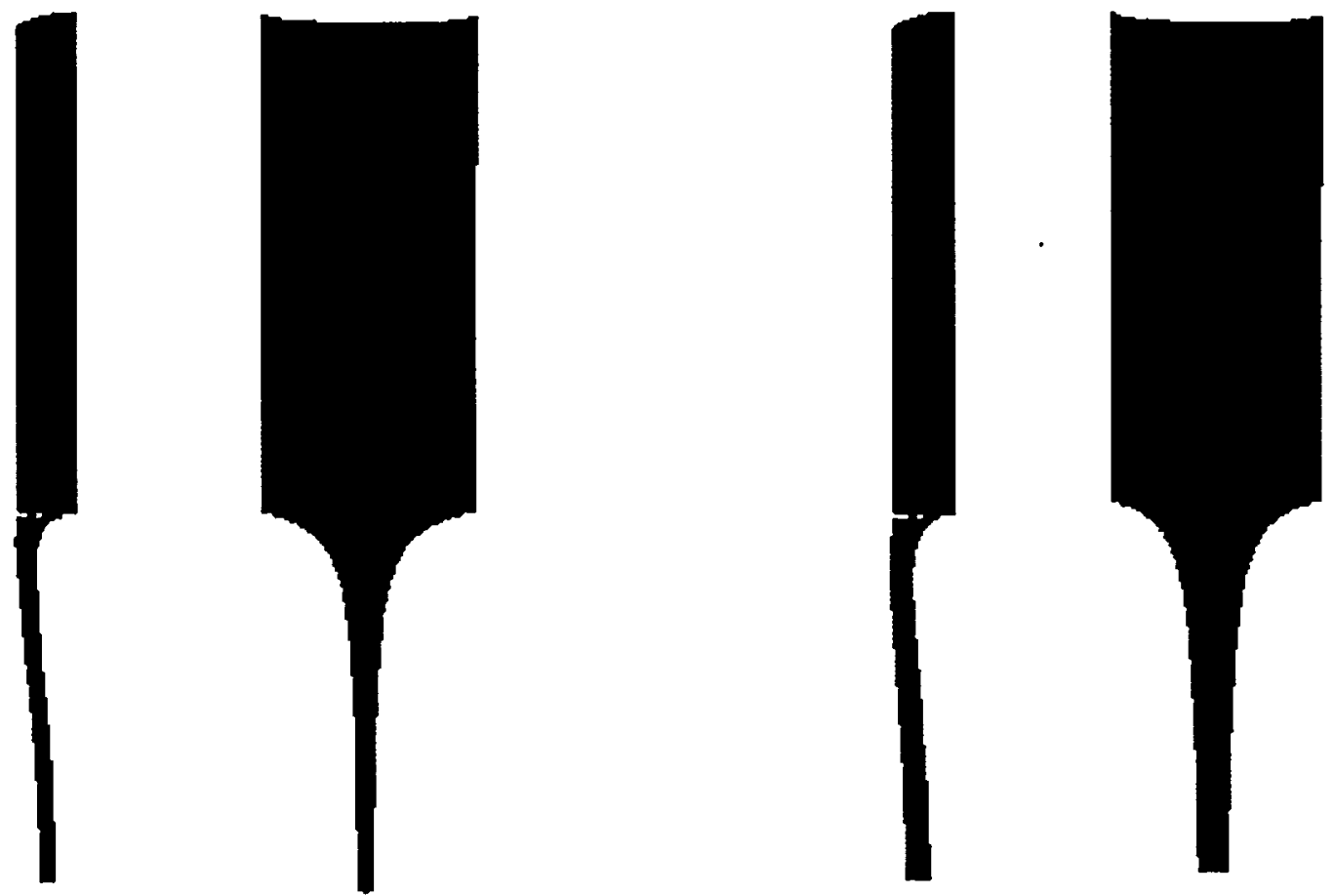

$\mathrm{t}=7.62 \mathrm{~s}$

(a)

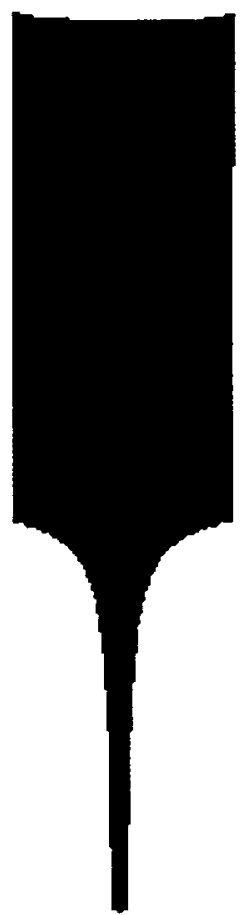

$\mathrm{t}=\mathbf{8 . 6 2 \mathrm { s }}$

(b)

Figure $8 \mathrm{a}$ shows the glass flow profile for the above case at steady state time of $7.62 \mathrm{~s}$. Figure $8 \mathrm{~b}$ shows the flow at $\mathrm{t}=8.62 \mathrm{~s}$ which has not yet reached steady state, as the downstream flow thickness is larger. 


\section{Case 5:}

\section{3in before the knife-edge + 4in after the knife-edge}

$\dot{m}=159 \mathrm{lb} / \mathrm{hr} \quad \bar{V}_{i}=0.073 \mathrm{~m} / \mathrm{s}$

$\rho=2500 \mathrm{~kg} / \mathrm{m}^{3} \quad \mu=7 \mathrm{~kg} / \mathrm{m} \cdot \mathrm{s} \quad \sigma=0.3 \mathrm{n} / \mathrm{m}$

Contact Angle $=70^{\circ}$ 00000 Cells
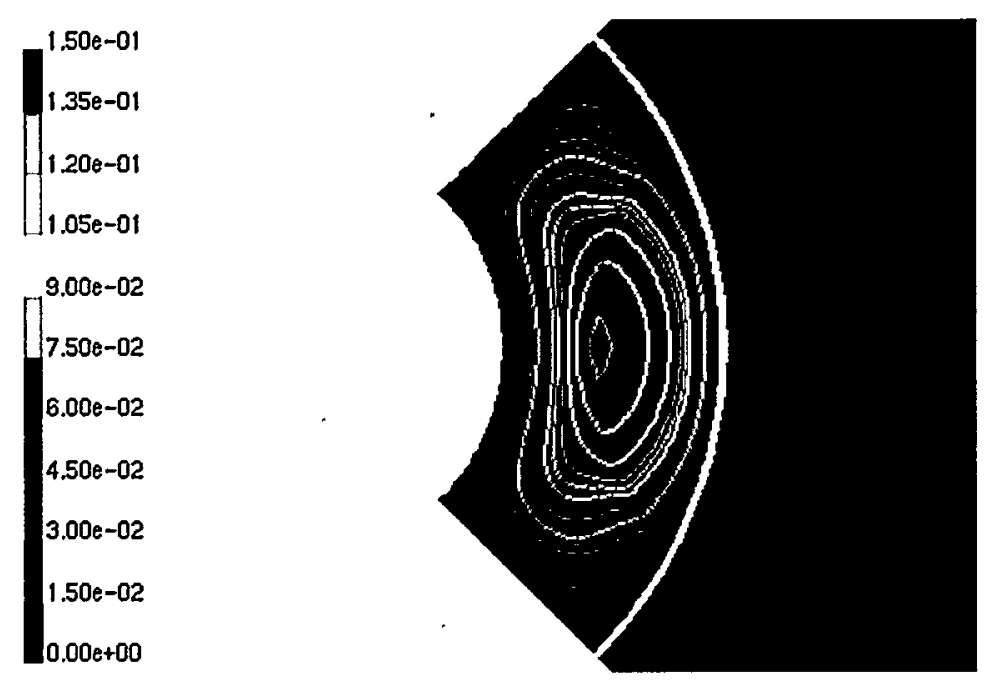

(a)

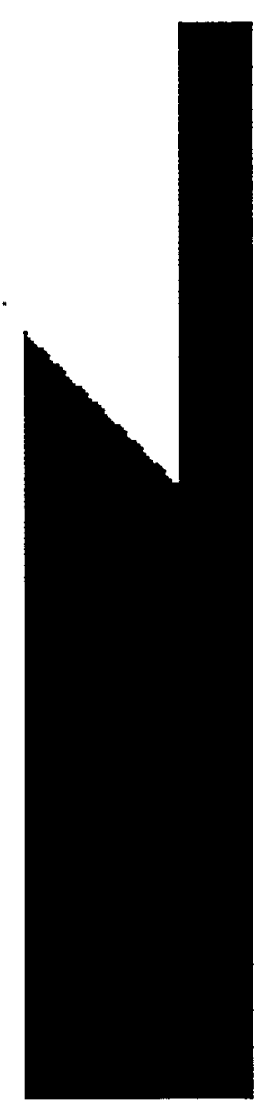

(b)

Figure 9. Contours of Velocity Magnitude, $70^{\circ}$ Contact Angle

This case shows the effect of a large contact angle of $70^{\circ}$ (Figure 9a). Figure 9a also shows the contours of velocity within the glass stream in contact with the spout wall. This case was not continued to reach steady state due to computational time constraints. However, it serves to show the tendency of bending back of the stream (Figure 9b) when the cross-section of the stream on the pour spout is convex. 


\section{Case 6:}

4in before the knife-edge +3 in after the knife-edge $\dot{m}=148 \mathrm{lb} / \mathrm{hr} \quad \bar{V}_{i}=0.057 \mathrm{~m} / \mathrm{s}$

$\rho=2500 \mathrm{~kg} / \mathrm{m}^{3} \quad \mu=10 \mathrm{~kg} / \mathrm{m} \cdot \mathrm{s} \quad \sigma=0.3 \mathrm{n} / \mathrm{m}$

Contact Angle $=30^{\circ}$ 72000 Cells

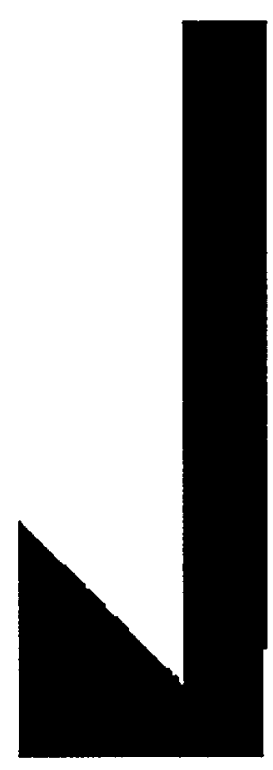

(a)

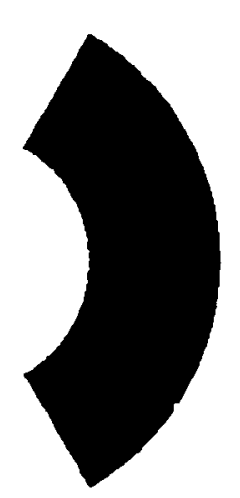

(b)

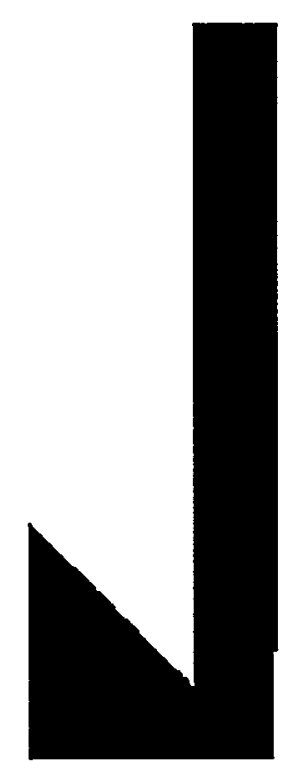

(a)

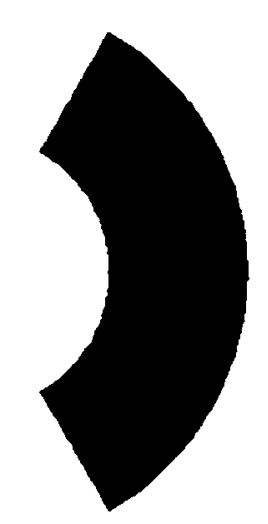

(b)

Figure 10

Figure 11

The same model in case 4 was used for this case to study the effects of viscosity. Viscosity was increased from 70 to 100 poise. A contact angle of $30^{\circ}$ was assigned. Figures $10 \mathrm{a}$ and $120 \mathrm{~b}$ show 
the glass flow at $t=1.02 \mathrm{~s}$. Figures $11 \mathrm{a}$ and $11 \mathrm{~b}$ show the flow at $\mathrm{t}=1.22 \mathrm{~s}$. Figures $10 \mathrm{~b}$ shows the surge height to be higher for this higher viscosity case, as compared with the lower viscosity of 70 poise, Figure $8 \mathrm{~b}$. Figure $11 \mathrm{~b}$ shows the top of the surge coming in contact with the inner wall. The inner-to-outer wall spacing was reduced intentionally to save computer memory and running time.

\section{Conclusions}

FLUENT predictions of glass pouring process and the effects of contact angles seem to be quite reasonable as compared to experimental results of the FIU and Clemson tests. The predictions do not show any breakup or splitting of the flow downstream of the wedge, as was observed in previous versions of FLUENT. It was determined that the length of the section upstream of the knife-edge and the inlet velocity profile assignment greatly affects the glass flow profile downstream of the knife-edge. This length needs to be at least 6 -in for the $30^{\circ}$ contact angle. It can be reduced to 4-in for $70^{\circ}$ contact angle. The length of the section downstream of the knife-edge also effects the flow profile. This was due to the assignment of pressure boundary condition at the exit, which forces the flow to be normal at this section (zero pressure gradient along the flow direction). Length of this section also needs to be about 6 inches.

It was determined that the refinement of the mesh where the glass attaches to the walls will affect the final flow profile. As the width of the wetted chord almost changed $100 \%$ for $30^{\circ}$ contact angle vs. $70^{\circ}$, there is need for two distinct models for the two contact angles. Also, in the downstream portion of the model where the glass is falling freely, there needs to be at least 3 to 4 cells across the glass ribbon diameter. Otherwise, there can be breakage of flow, or false deflections.

\section{Possible Future Work}

Recommendations for the future work include the following:

3-D Modeling of the horizontal section of the spout, and the vertical sections should include both knife-edges. A 2-in long 4-in diameter horizontal section is required to produce the correct inlet velocity to the vertical section. A 9-in long 2 -in diameter vertical section will produce accurate contact profile and enough length for the flow to fully develop before the first knife-edge. A 6-in long 3-in diameter vertical section should produce an accurate profile up to the second knife-edge. And finally, a 2-in long 4-in diameter section to predict the glass separation from the second knife-edge. This could be achieved through a model with about 150000 cells.

* The effects of temperature on the viscosity of the glass should be modeled through assignment of variable viscosity. As CFD programs can not handle radiation effects in transient problems, a variable convection coefficient should be assigned to the region of interest to produce the desired temperature drop, or the experimentally determined thermal gradients can be impressed on the metallic components of the model.

* Both steady state and variable flow rate tests should be conducted. A limited number of experimental runs should be conducted to validate the model.

* Initial conditions should be used which include realistic wetting conditions of the backside of the knife-edge and of the inner surface of the spout. 


\section{References}

1. H. N. Guerrero, H. N. Naseri-Neshat, "Computer Modeling of a Glass stream Departing From A Pour Spout Knife Edge," Proceedings of the $3^{\text {rd }}$ ASME/JSME Joint Fluids Engineering Conference July 18-23, 1999, San Francisco, California.

2. H. N. Guerrero, "Theoretical Basis for the DWPF Melter Pouring Instabilities," SRT-ETF960028, April 19, 1996.

3. J. U. Brackbill, D. B. Kothe, and C. Zemach, "A Continuum Methods for Modeling Surface Tension," Journal of Computational physics 100, 335-354 (1992).

4. Hubbert, H. E., "Flow instability of a viscous Current Down a Slope," Nature, Vol.300, P427, 1982.

5. Hocking, L. M., "Spreading and Instability of a Viscous Fluid Sheet," Journal of fluid Mechanics, Vol.221, pp. 373-392, 1990.

6. Silvi, N. and E. B. Dussan V, "On the Rewetting of an Inclined Surface by a Liquid," Physics of Fluids, Vol.28, No.1, January 1985.

7. Hocking, L. M. and M. Miksis, "Stability of a Ridge of Fluid," Journal of Fluid Mechanics," Vol.247, pp, 157-177, 1993. 